\author{
Universidade de Brasília \\ Instituto de Artes \\ Departamento de Design \\ Programa de Pós-graduação em Design
}

Marina Dourado Lustosa Cunha

\title{
m-learning: Proposta de ambiente de aprendizagem por projetos baseada em metodologias colaborativas
}




\section{m-learning: Proposta de ambiente de aprendizagem por projetos baseada em metodologias colaborativas}

Dissertação apresentada ao Programa de Pós-Graduação em Design da Universidade de Brasília, na linha de pesquisa Design, Cultura e Sociedade, como requisito parcial para a obtenção do título de Mestre em Design.

Orientadora:

Prof. ${ }^{a}$ Dr. ${ }^{a}$ Daniela Fávaro Garrossini 
Ficha catalográfica elaborada automaticamente, com os dados fornecidos pelo(a) autor(a)

m-learning: Proposta de ambiente de aprendizagem por projetos baseada em metodologias colaborativas / Marina Dourado Lustosa Cunha; orientador Daniela Fávaro Garrossini. -- Brasília, 2015. $127 \mathrm{p}$.

Dissertação (Mestrado - Mestrado em Design) -Universidade de Brasília, 2015.

1. m-learning. 2. App. 3. Mobile. 4. TICs. 5. Aprendizado Baseado em Projetos. I. Garrossini, Daniela Fávaro, orient. II. Título. 


\section{M-LEARNING: PROPOSTA DE AMBIENTE DE APRENDIZAGEM POR PROJETOS BASEADA EM METODOLOGIAS COLABORATIVAS}

\section{Marina Dourado Lustosa Cunha}

Dissertação submetida ao Programa de Pós-Graduação em Design do Instituto de Artes da Universidade de Brasília como parte dos requisitos para a obtenção do grau de Mestre em Design.

Aprovada por:

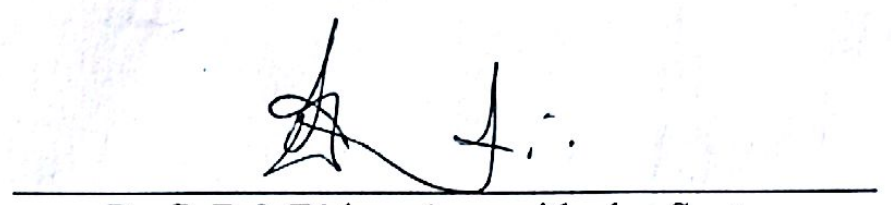

Prof ${ }^{\mathrm{a}}$. Dr ${ }^{\mathrm{a}}$. Fátima Aparecida dos Santos IdA/DIn/UnB

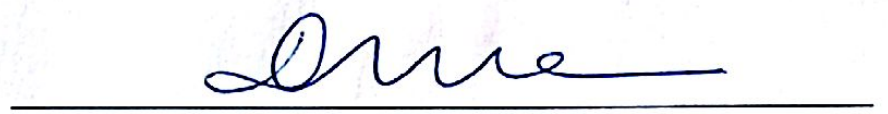

Prof $^{a}$. Dr. ${ }^{a}$ Dianne Magalhães Viana $\mathrm{Id} \mathrm{A} / \mathrm{DIn} / \mathrm{UnB}$

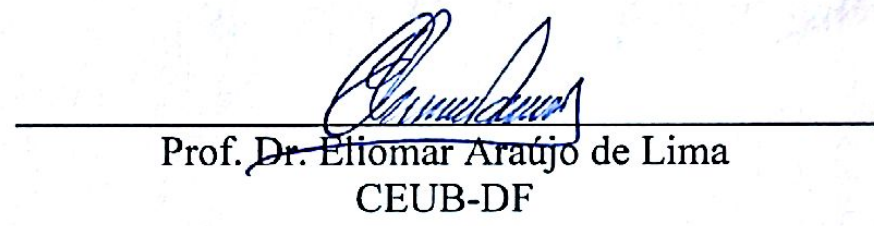

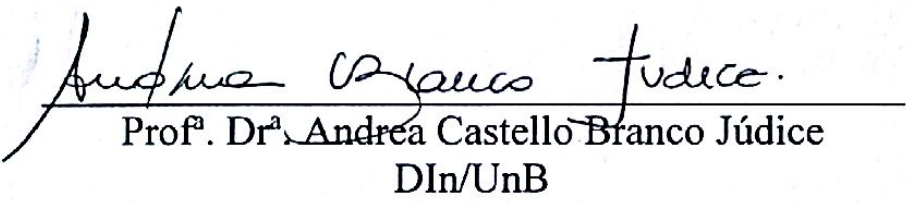

Brasília-DF, 14 de Dezembro de 2015

Coordenação do Programa de Pós-Graduação em Design/Instituto de Artes/UnB 


\section{Agradecimentos}

A todos que contribuíram direta ou indiretamente para o desenvolvimento deste trabalho, em especial:

À minha família, meus pais, Maristela e Raimundo, que apesar de todas as dificuldades do sertão piauiense e da migração quando tão jovens ao planalto central, sempre se esforçaram para priorizar meus estudos e me motivaram a lutar pela minha jornada acadêmica; e à minha irmã, Mariana, pelo apoio e companheirismo.

À minha orientadora, $\operatorname{Prof}^{a} \operatorname{Dr}^{\mathrm{a}}$ Daniela Fávaro Garrossini, desde o início da graduação, pela inspiração, pelos constantes incentivos, pelo reconhecimento e valorização, pelos ensinamentos que vão além do Design e por possibilitar a minha participação no Núcleo de Multimídia e Internet, onde vivenciei experiências enriquecedoras que contribuíram para a minha formação tanto pessoal quanto acadêmica.

À equipe de pesquisa e desenvolvimento do Tiê, Gabriel Gaspar, Matheus Souza, Jéssica Cantieri, Helena Simões, Raquel Pacheco, Mariana Bergo, Guilherme Peres, Romane de Aragão e Gabriel Marques.

Ao amigo e também integrante da equipe de desenvolvimento do Tiê, Matheus Parreiras, pela constante ajuda, motivação e apoio, indispensáveis para a finalização deste trabalho.

Às pesquisadoras do NMI, Cristiane Arakaki, Andrea Júdice e Ana Carolina Kalume, por todo o estímulo, apoio e dedicação.

Aos amigos e bolsistas do Núcleo de Multimídia e Internet.

Aos professores e alunos do Projeto Integrador, de iniciativa da $\operatorname{Prof}^{\mathrm{a}} \operatorname{Dr}^{\mathrm{a}}$ Dianne Magalhães Vianna. 


\section{Resumo}

Esta dissertação tem como objetivo apresentar a proposta de um ambiente digital que permite a gestão colaborativa de projetos, com base nos princípios da facilitação da recuperação das informações, da manutenção do histórico de projetos, do auxílio na gestão do conhecimento e da gestão colaborativa por meio do aprendizado utilizando dispositivos móveis, o m-learning. Para tanto, o desenvolvimento do software ao longo desta pesquisa foi planejado e desenvolvido de maneira colaborativa, em uma equipe interdisciplinar, buscando inicialmente atender aos processos colaborativos de estudantes de ensino superior, e resultando em um ambiente que pode ser utilizado em diversos setores da sociedade, ultrapassando o contexto universitário. Este trabalho utilizou metodologias participativas e colaborativas para a sua construção, preenchendo uma lacuna na área de desenvolvimento de projetos, na qual equipes interdisciplinares trabalham colaborativamente e participativamente, de maneira inovadora, aliando as novas tecnologias da informação e da comunicação aos métodos e processos atuais de gestão de projetos.

\section{Palavras-chave}

m-learning, App, Mobile, TICs, Aprendizado Baseado em Projetos 


\begin{abstract}
This thesis aims to present a proposal for a digital environment that enables collaborative project management, based on the principles of facilitating information retrieval, project history maintenance, assisting in knowledge management and collaborative management through mobile learning. Therefore, the software developed along with this research was planned and developed collaboratively in an interdisciplinary team, initially seeking to meet the necessities of collaborative processes of higher education students, and then resulting in a digital environment that can be used in many sectors of society, surpassing the academic context. This study used participatory and collaborative methodologies for its construction, filling a gap in the project development area, in which interdisciplinary teams work collaboratively and in a participatory way, in an innovative way, combining the new information and communication technologies to current methods and processes of project management.
\end{abstract}

\title{
Keywords
}

m-learning, App, Mobile, ICTs, Project-based Learning 


\section{Lista de figuras}

Figura 1: Linha do tempo metodológica do trabalho 24

Figura 2: Respostas às questões sobre organização do projeto e frequência às reuniões

Figura 3: Sistemas operacionais utilizados pelos estudantes do Projeto Integrador no dispositivo móvel que mais utilizavam 29

Figura 4: Representação das equipes do Projeto Integrador ..... 31

Figura 5: Ambiente de atualização do andamento do projeto no Flow........................ 38

Figura 6: Exemplo de página de projeto dentro do Flow. 39

Figura 7: Página inicial do Basecamp em 2012, listando as informações agrupadas pelo ambiente. 41

Figura 8: Exemplo de ambiente de projeto no Basecamp. 41

Figura 9: Exemplo de ambiente de tarefas no Basecamp.......................................... 42

Figura 10: Exemplo de ambiente de tarefas no Basecamp......................................... 43

Figura 11: Exemplo de página inicial ao entrar no ambiente do Basecamp. 44

Figura 12: Exemplo do progresso diário de um usuário no Basecamp, agrupando as atividades por projeto. 45

Figura 13: Exemplo de discussão em um cartão do Trello. 47

Figura 14: Exemplo de cartão do Trello........................................................................ 48

Figura 15: Exemplo de quadro do Trello.................................................................. 49

Figura 16: Tiê-sangue (Ramphocelus bresilius) ....................................................... 51

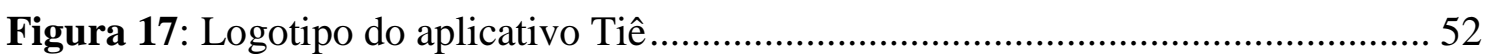

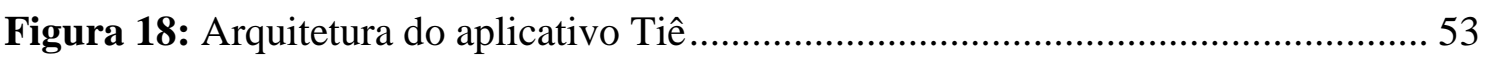

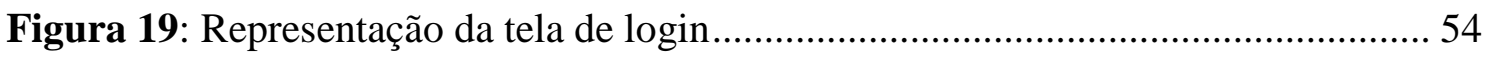

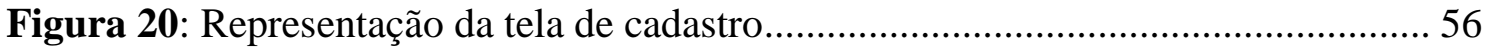

Figura 21: Representação do mural de projetos do usuário .......................................... 58

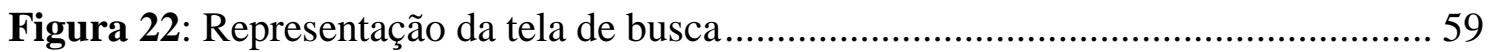

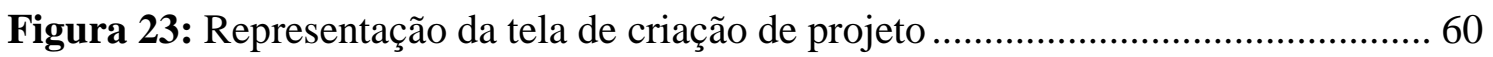

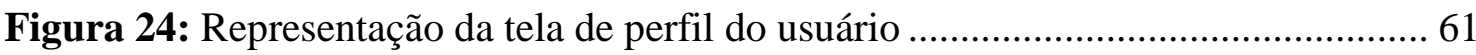

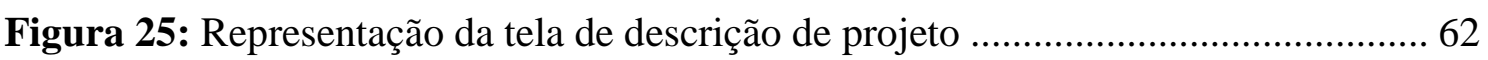

Figura 26: Representação da tela de linha do tempo de projeto..................................... 63

Figura 27: Representação da tela de fóruns do projeto ................................................. 65

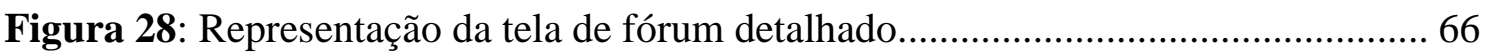


Figura 29: Representação da tela de criação de um novo fórum 67

Figura 30: Representação da tela de listagem de arquivos..... 68

Figura 31: Representação da tela de calendário 69

Figura 32: Representação da tela de evento detalhado ............................................ 70

Figura 33: Representação da tela de criação de um novo evento................................... 71

Figura 34: Representação da tela de lista de tarefas ....................................................... 72

Figura 35: Representação da tela de tarefa detalhada .................................................. 73

Figura 36: Representação da tela de criação de uma nova tarefa.................................. 74

Figura 37: Recorte da arquitetura do Tiê, com foco na sequência de navegação para acesso aos fóruns

Figura 38: Recorte da arquitetura do Tiê, com foco na sequência de navegação para acesso às tarefas.

Figura 39: Exemplo de exibição dos comentários em uma tarefa (à esquerda) e do menu de organização da exibição de tarefas (à direita).

Figura 40: Recorte da arquitetura do Tiê, com foco na sequência de navegação para acesso aos eventos

Figura 41: Recorte da arquitetura do Tiê, com foco na sequência de navegação para acesso aos arquivos

Figura 42: Exemplo de exibição da linha do tempo de um projeto no Tiê (à esquerda) e do menu lateral (à direita). 80

Figura 43: Exemplo de exibição da tela de avisos (à esquerda) e da tela de projetos (à direita)

Figura 44: Disposição dos termos utilizados no sistema para validação 84

Figura 45: Discussão dos termos em conjunto após a definição individual pelos participantes 86

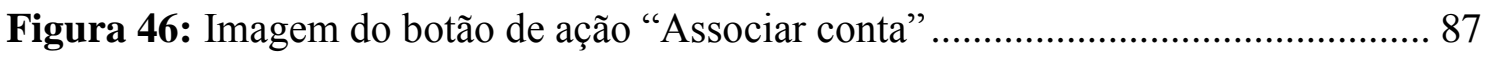

Figura 47: Captura da tela "Meus arquivos" dentro do ambiente ................................. 88

Figura 48: Captura de tela do mural do projeto dentro do ambiente. 89

Figura 49: Captura de tela do aplicativo Google Fit, ilustrando um exemplo de botão de ação, destacado em amarelo 90

Figura 50: Capturas de tela da solução desenvolvida..... 92 


\section{Lista de quadros}

Quadro 1: Diferenças entre as reuniões das equipes do Projeto Integrador...

Quadro 2: Soma das respostas obtidas na avaliação $360^{\circ}$ obtida por meio do

Questionário 1

Quadro 3: Requisitos necessários a um ambiente para desenvolvimento e gestão de projetos colaborativos

Quadro 4: Descrição das informações a serem agrupadas em ambientes para o gerenciamento colaborativo de projetos

Quadro 5: Questões norteadoras para a análise dos ambientes

Quadro 7: Listagem dos termos utilizados no ambiente e selecionados para validação 


\section{Lista de abreviaturas e siglas}

BIE: Buck Institute for Education (do inglês, Instituto Buck para a Educação)

DEG/UnB: Decanato de Ensino de Graduação da Universidade de Brasília

EAD: Educação à distância

e-learning: Electronic learning (do inglês, Aprendizado eletrônico)

m-learning: Mobile learning (do inglês, Aprendizado móvel)

NMI/UnB: Núcleo de Multimídia e Internet da Universidade de Brasília

PBL: Project-Based Learning (do inglês, Aprendizado Baseado em Projetos)

SO: Sistema operacional

TICs: Tecnologias da Informação e da Comunicação

UnB: Universidade de Brasília 


\section{Sumário}

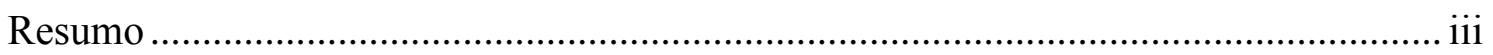

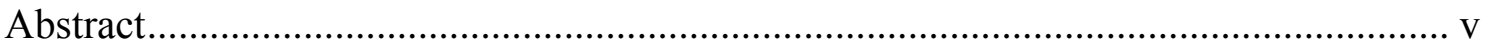

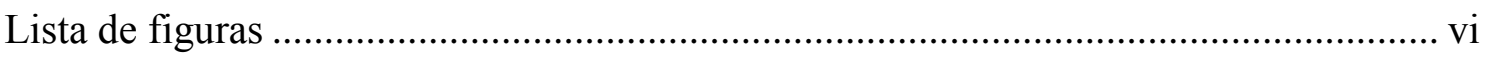

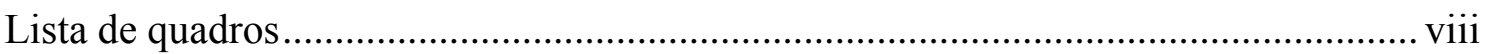

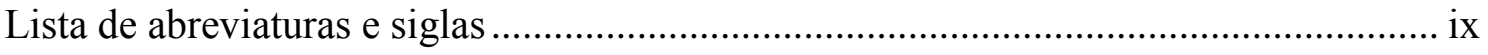

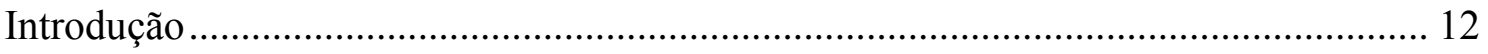

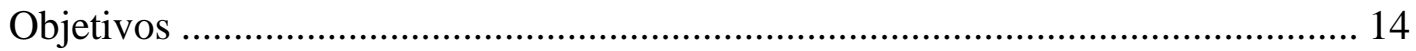

$1^{\circ}$ Capítulo: Embasamento teórico acerca dos conceitos fundamentais para as estratégias em m-learning 16

$2^{\circ}$ Capítulo: Análise contextual e metodológica com foco no ambiente de aprendizagem baseada em projetos para a educação superior .

2.1 Contextos e necessidades do desenvolvimento dos projetos colaborativos

2.2 Requisitos para a concepção de espaços digitais que que apoiem a comunicação e o registro de projetos colaborativos

2.3 Análise das soluções para o gerenciamento de projetos colaborativos 35

2.4 Necessidade da construção de um ambiente colaborativo para auxiliar a comunicação e o registro de projetos colaborativos

$3^{\circ}$ Capítulo: Proposta de ambiente de aprendizagem por projetos baseada em metodologias colaborativas

3.1 Construção de um aplicativo para o gerenciamento de projetos colaborativos. 51

3.2 Análise da solução projetada .75

3.3 Validação dos termos utilizados na solução desenvolvida 81

3.4 Análise dos resultados obtidos na fase de avaliação 86

Capítulo 4: Conclusões 93

Referências 95

Anexos 98 
Anexo I: Questionário sobre o perfil dos alunos do Projeto Integrador com relação ao uso de dispositivos móveis

Anexo II: Respostas ao questionário sobre o perfil dos alunos do Projeto Integrador com relação ao uso de dispositivos móveis 102

Anexo III: Questionário sobre a percepção individual dos alunos do Projeto Integrador quanto ao desenvolvimento do projeto e o relacionamento com a equipe

Anexo IV: Respostas ao questionário sobre a percepção individual dos alunos do Projeto Integrador quanto ao desenvolvimento do projeto e o relacionamento com a equipe

Anexo V: Questionário do perfil dos participantes da avaliação dos termos utilizados no ambiente desenvolvido.

Anexo VI: Respostas ao questionário do perfil dos participantes da avaliação dos termos utilizados no ambiente desenvolvido

Anexo VII: Roteiro da avaliação de usabilidade

Anexo VIII: Roteiro das avaliações em contexto do ambiente desenvolvido 


\section{Introdução}

A Aprendizagem Baseada em Projetos (PBL) é um dos modelos que fogem da educação tradicional é e aplicada em classes que vão desde o ensino fundamental até a educação superior, estimulando os alunos a adquirir conhecimentos e habilidades além da sala de aula, trabalhando em grupos interdisciplinares, realizando questionamentos complexos e gerando soluções colaborativas. Desta forma, o PBL torna possível desenvolver habilidades e competências que normalmente não são estimuladas nos métodos de ensino tradicionais.

Este modelo é aplicado na Universidade de Brasília (UnB) em várias iniciativas presentes em seus campi. Uma delas é o projeto integrador coordenado pelo Departamento de Engenharia Mecânica, movido pelo desafio de se projetar a atividade de coleta seletiva de lixo na Universidade. Os aproximadamente sessenta alunos que participam ao longo da disciplina são oriundos de vários cursos, como as Engenharias Mecânica, Elétrica e Mecatrônica, Design, Administração e Serviço Social, ou seja, uma equipe interdisciplinar que estuda as questões organizacionais, políticas e econômicas no projeto e na implementação de centrais de coleta seletiva de materiais recicláveis em um projeto piloto cuja área englobava inicialmente o campus Darcy Ribeiro (Viana et al, 2011), idealizando um processo de coleta seletiva em todas as suas etapas: coleta, a ser realizada por um veículo elétrico também projetado e construído pelos estudantes, triagem e descarte de resíduos recicláveis.

No ano de 2011 foi publicado um edital do Decanato de Ensino de Graduação (DEG/UnB) que apoiava projetos de utilização de Tecnologias da Informação e Comunicação no ensino de graduação na Universidade. Esta oportunidade possibilitou o desenvolvimento de um projeto de comunicação entre os grupos do Projeto Integrador, pois verificou-se, a partir da análise das respostas obtidas com a aplicação de questionários ao grupo de estudantes, que as informações do projeto estavam concentradas em alguns poucos estudantes que atuavam como líderes de determinadas etapas, o que resultava na perda de estímulo do restante dos colegas, pois estes não compreendiam sua contribuição para o resultado final. $\mathrm{O}$ foco deles estava no desenvolvimento individual das tarefas, sem contato constante com os outros alunos que estavam trabalhando em outras etapas. 
Após observar o desenvolvimento de outros projetos, tanto no âmbito do PBL quanto fora dele, observou-se que as falhas na comunicação e a perda de noção da totalidade do projeto são problemas comuns. A informação costuma ser perdida devido à falta de registros de reuniões e a e-mails que nem sempre chegam a todos da equipe ou nem ao mesmo são lidos, por exemplo. Dados importantes para o projeto, tais como arquivos, datas de entrega e as atribuições de quem iria desenvolver qual tarefa, são esquecidos.

O projeto de comunicação englobou a pesquisa e o desenvolvimento de um aplicativo para dispositivos móveis que seja um ambiente no qual possam ser gerenciadas todas as informações relativas ao projeto, permitindo a visualização destas por todos os membros da equipe, auxiliando o registro e a troca de informações em disciplinas com base no PBL. Esta proposta foi desenvolvida ao se pesquisar que é possível aplicar o Mobile learning (m-learning) em conjunto com o PBL, visto que esta abordagem instiga estudantes a trocar informações de forma dinâmica e em tempo real, apesar de apresentar a possibilidade de dificultar o resgate posterior das informações trocadas entre os estudantes, pois com as trocas constantes de arquivos, várias conversas, tarefas e datas importantes, é difícil resgatar esses dados de forma eficiente e relevante em situações futuras.

Desta maneira, o intuito do ambiente resulta em permitir que todos dentro da equipe troquem informações relativas ao projeto a qualquer momento e em qualquer lugar, além de manter registro das conversas, tarefas, datas importantes para o projeto, arquivos de referência e arquivos produzidos, por exemplo. Assim, cabe a cada integrante decidir se quer visualizar o projeto integralmente, visualizar apenas as informações relativas à etapa do projeto na qual está trabalhando, ou se deseja filtrar para ter acesso somente a arquivos, ou a tarefas a serem realizadas dentro do projeto, por exemplo. Este projeto está sendo desenvolvido desde 2012 por uma equipe de estudantes de graduação e pós-graduação da UnB sob a orientação da professora Daniela Garrossini, do departamento de Design da UnB.

Considerando-se estes problemas, observou-se a necessidade da realização de uma análise sistêmica dos grupos de estudantes que participam de disciplinas que têm o PBL como base, com vistas a compreender como é realizada a gestão do conhecimento, estudando a contribuição das disciplinas da Universidade para o desenvolvimento da sociedade que a tangencia. 


\section{Objetivos}

Portanto, o objetivo geral deste trabalho é propor um ambiente digital que permita a gestão colaborativa de projetos, com base nos princípios de facilitar a recuperação das informações, manter histórico do projeto, auxiliar na gestão do conhecimento e permitir a gestão colaborativa por meio do m-learning .

Os objetivos específicos deste estudo são:

- Observar e analisar os contextos e as necessidades de desenvolvimento de projetos colaborativos para ensino de graduação;

- Identificar e analisar as condições existentes para o gerenciamento de informação e comunicação em projetos colaborativos;

- Gerar possibilidades de contribuição à concepção de espaços colaborativos, viabilizando a construção de uma solução que propicie a gestão colaborativa de projetos.

Logo, o presente trabalho foi dividido em três capítulos: o primeiro apresenta os conceitos-chave para a compreensão do estudo: teoria sistêmica, aprendizagem colaborativa, PBL, m-learning, gestão do conhecimento e comunicação em projetos. Desta maneira, é possível analisar os processos de troca e construção do conhecimento, questionando a atual conjuntura que inibe o registro da informação.

No segundo capítulo são apresentadas a entrevista conduzida com as professoras envolvidas no desenvolvimento do Projeto Integrador e os questionários aplicados aos estudantes de graduação desta iniciativa, cujas respostas culminam na concepção dos requisitos para ambientes colaborativos com base digital, construídos a partir destes estudos. Em seguida são descritas as análises empreendidas para compreender quais as soluções atuais para o gerenciamento de projetos colaborativos.

Em seguida, no terceiro capítulo, é apresentado o processo de planejamento e desenvolvimento do aplicativo mencionado previamente, constando a arquitetura da informação, os wireframes e as imagens da solução planejada, ilustrando como ela busca atender aos requisitos. Em sequência, é apresentada a dinâmica de validação dos termos utilizados no aplicativo desenvolvido, com o objetivo de verificar a acessibilidade e a compreensão dos termos por outros contextos de desenvolvimento de projetos colaborativos. Por fim, após a apresentação dos resultados obtidos, faz-se uma 
reflexão das conclusões obtidas com a realização deste trabalho, apontando também as contribuições para o campo de estudo e considerando possibilidades para trabalhos futuros. 


\section{$1^{\circ}$ Capítulo: Embasamento teórico acerca dos conceitos fundamentais para as estratégias em m-learning}

Este primeiro capítulo apresenta e discute os seguintes conceitos-chave para a compreensão do estudo: teoria sistêmica, aprendizagem colaborativa, PBL, m-learning, gestão do conhecimento e comunicação em projetos. Com estas definições em mente, é apresentada a revisão de literatura, cujo objetivo é a análise dos processos de troca e construção do conhecimento.

O aprendizado colaborativo é baseado em um modelo que promove trocas de conhecimento dinâmicas e constantes entre alunos e professores, tornando cada experiência de aprendizagem única ao ajustar os conteúdos trabalhados às necessidades encontradas ao longo do processo sem remover a autoridade do professor enquanto avaliador do processo, promovendo a participação ativa de todos na construção do conteúdo.

Deste modelo derivaram-se o Project-Based Learning e o Problem-Based Learning (PBL), nos quais os alunos trabalham em grupo para solucionar problemas e projetos, diferindo da educação tradicional, com vistas ao desenvolvimento de habilidades e competências vinculadas às necessidades de contextos reais, demandados fora do ambiente de sala de aula. Por isso, os projetos desenvolvidos são normalmente interdisciplinares.

Markham (2012) define o PBL como um processo contínuo de aprendizagem que estimula os alunos a ter uma atitude ativa: eles devem buscar desafios e realizar questionamentos com o objetivo de estimular habilidades a serem utilizadas dentro e fora de sala de aula, contando com a orientação de um professor.

De forma complementar a esta definição, Carvalho e Lima (2006) e Moreira e Sousa (2008), apontam que o PBL é uma abordagem de aprendizagem que usa problemas reais para enfocar, motivar e facilitar a aprendizagem de conhecimentos conceituais, procedimentais e atitudes relevantes à futura atuação do estudante como profissional e cidadão.

Ou seja, os alunos decidem como abordar um problema e em quais atividades dar maior ou menor prioridade. Eles reúnem e analisam informações de várias fontes, baseando seu conhecimento a partir destas. Assim, o aprendizado se torna muito mais 
rico devido porque se aproxima da realidade, envolvendo habilidades de colaboração, reflexão e proatividade. Desta maneira, o papel do professor nesse modelo é orientar, e não dirigir e gerenciar diretamente o trabalho dos alunos. A avaliação dos projetos é feita de modo contínuo e não baseado somente no trabalho final. (BIE, 2015)

O PBL é aplicado nos mais diversos tipos de contextos educacionais, em classes que vão desde o ensino fundamental até a educação superior, de modo a estimular os alunos a trabalharem em grupos interdisciplinares, fomentando atitudes questionadoras complexas e buscando soluções colaborativas.

O Buck Institute for Education - BIE (2015) destaca em seu site o papel dos alunos como atores ativos na construção do conhecimento ao evidenciar que, em uma classe baseada em PBL, eles aprendem e retêm mais conteúdo se comparado à educação tradicional, pois aplicam o que aprenderam a novas situações, desenvolvendo competências-chave como resolução de problemas, pensamento crítico, colaboração, comunicação, criatividade e inovação.

O instituto ainda descreve que esses projetos são guiados por questões interdisciplinares que estimulam e motivam os estudantes a buscar, pensar e construir soluções em conjunto, gerenciando seus próprios projetos, definindo quais atividades têm maior ou menor relevância sob a orientação de um professor, visto que a oportunidade de interagir com outros estudantes num projeto interdisciplinar é uma das vantagens da participação na aprendizagem colaborativa. A aplicação prática dos conteúdos e a aproximação da realidade profissional contribuem para o aumento da motivação e do empenho ao longo do projeto (LIMA et al, 2009).

Além disso, há espaço para que os estudantes deem e recebam críticas sobre a qualidade dos trabalhos. Em alguns casos os trabalhos são apresentados para o público externo, além de seus colegas de classe e professores, reforçando a aproximação com demandas e necessidades reais.

Em suma, segundo Garrossini et al (2012), o PBL não soluciona todos os problemas do ensino tradicional, mas responde a questões essenciais como interdisciplinaridade, integração entre teoria e prática e a aproximação dos mundos da sala de aula e do trabalho, promovendo a construção de conhecimento além do que estava programado no currículo. 
Em seu site, o BIE também reafirma o papel das Tecnologias da Informação e da Comunicação (TICs) como aliadas do PBL, ainda mais por serem tão presentes no cotidiano das novas gerações. As TICs possibilitam a integração de parceiros, especialistas, e público geral de qualquer parte do mundo com a sala de aula, permitindo encontrar recursos e informações, criar produtos, e colaborar de forma mais eficaz.

Nota-se que de acordo com Vygotsky (1978), a interação social desempenha um papel crucial no processo de aprendizagem, e é nesse contexto que estudos demonstram que a aprendizagem colaborativa apoiada em tecnologia promove a facilitação da comunicação, o aumento da percepção em relação às formas de trabalho, e permite a obtenção de altos níveis de interação social nas salas de aula.

Observou-se também que para alcançar altos níveis de interação social é necessário não apenas a participação ativa individual, como também, a construção dinâmica de significados pelo processo de alta ordem cognitiva que envolve concentração, raciocínio lógico, concepções de formação, análise, raciocínio e avaliação.

Atualmente ainda há a possibilidade de ir além do e-learning por meio do uso de dispositivos móveis juntamente ao PBL, possibilitando enriquecer as práticas em EAD, permitindo ir além do aprendizado por meio da web.

Deegan e Rothwell (2010) definem m-learning como "aprendizado com o auxílio de um dispositivo móvel". Este aparelho pode ser um tablet, um smartphone ou até consoles de videogames portáteis, o que permite a aplicação do PBL em ambientes colaborativos, possibilitando aos estudantes trabalhar no projeto de forma síncrona ou assíncrona, dentro ou fora de sala de aula. Isso representa um novo passo adiante para as práticas em educação à distância (EAD), pois abrange novos modelos de ensinoaprendizagem complementares, não mais restringindo as trocas de informação ao tempo e espaço de emissores e receptores. Os alunos têm a oportunidade de aprender em qualquer lugar que estejam e de compartilhar conhecimento a qualquer momento, estimulando as trocas de informação entre estudantes de forma dinâmica e em tempo real.

Porém, esse impulso nas comunicações entre participantes pode aumentar o volume de conteúdo compartilhado, acumulando informação e impossibilitando ao 
aluno distinguir o que é relevante para ele caso a comunicação seja realizada por meio de mensagens, SMS e e-mails, sem filtragem e registro posteriores.

Não obstante, esse aumento nas trocas entre estudantes aumenta o risco de se concentrar informação em alunos específicos, o que impede o restante dos alunos de compreender o projeto por inteiro, restando-lhes apenas executar as tarefas específicas que forem repassadas. Desta forma há grandes chances destes alunos se sentirem desmotivados, levando-os a abandonar o grupo, pois não há senso de pertencimento ao projeto.

Deegan e Rothwell (2010) afirmam ainda que "[os aplicativos para m-learning] devem cumprir não somente as metas de indicadores, mas também aquelas dos educandos e eles devem fazê-lo de forma efetiva e eficaz ao mesmo tempo que provêm uma experiência satisfatória aos usuários" , ou seja, "se as pessoas acharem os aplicativos para m-learning insatisfatórios ou difíceis de usar, então o m-learning será deixado de lado como uma infraestrutura não-realista para a educação"2 (Deegan e Rothwell, 2010).

Observa-se, então, a existência de consequências na utilização do m-learning aliado ao PBL que representam desafios para o Design, pois as conversas, arquivos trocados, decisões, tarefas e prazos se acumulam, dificultando o resgate de informações quando necessário. A flexibilidade dos dispositivos móveis para complementar o ensino em sala de aula e a utilização do m-learning no sentido de auxiliar as práticas de educação à distância e/ou semipresencial representam uma oportunidade única para projetar a experiência de ensino em situações contemporâneas, visto que o aprendizado pode ocorrer de forma bidirecional, entre um professor e um aluno; em grupos, com a participação de um professor e os estudantes que compõem uma determinada turma; ou mesmo por vários professores e vários grupos de estudantes.

Ao utilizar o m-learning, é possível reconhecer as possibilidades tecnológicas do aprendizado em rede. Os estudantes se comunicam de forma direta, apoiando seu trabalho por meio de dispositivos móveis, interconectados por uma rede sem fio que

\footnotetext{
1 "'[m-learning applications] must accomplish not only the goals of indicator but also those of the individuals being educated and they must do this effectively and efficiently whilst also providing a satisfying experience to the users" (DEEGAN e ROTHWELL, 2010)

2 "[...] if people find m-learning applications dissatisfying or difficult to use then m-learning will be dismissed as an unrealistic infrastructure for education" (DEEGAN e ROTHWELL, 2010)
} 
permite uma comunicação verdadeiramente direta, através do dispositivo, proporcionado pela mobilidade da rede (KUMAR \& TURNER, 2006).

Com o uso de tablets, telefones celulares e consoles de videogames portáteis, a comunicação não se restringe mais a questões de local e tempo, pois estes dispositivos podem ser utilizados em qualquer lugar. Essa característica contribui para o desenvolvimento de projetos, permitindo o desenvolvimento de modelos de gerenciamento e acompanhamento de tarefas de forma não presencial e em tempo real com a participação de todos os integrantes da equipe.

Garrossini e Kalume (2014) ressaltam que o m-learning não se baseia somente nos processos de comunicação como mensagens e e-mails, mas também tem como base a mobilidade e os aplicativos desenvolvidos para que os estudantes possam compartilhar seus trabalhos e questionamentos, construindo conhecimento de forma colaborativa.

Ou seja, os dispositivos móveis aumentam o potencial para a troca de informação entre alunos ao ampliarem suas potencialidades de colaboração. Questões como lugar, trânsito, e conexão não são mais fatores que impedem o trabalho em equipe, pois não é mais necessário compartilhar uma área de trabalho fixa nem de conexão à Internet a todo momento, visto que é possível produzir conhecimento fisicamente e enviá-lo posteriormente, quando houver conexão.

Harasim et al (2005) afirma, com base em sua pesquisa e nos estudos anteriores de Hiltz e Wells, que "[...] os ambientes on-line proporcionam resultados iguais ou superiores aos alcançados nas aulas presenciais", já que as interações em rede permitem aos participantes ponderar sobre as questões levantadas, por meio de pesquisas em múltiplas fontes na Internet. A autora ainda apresenta os resultados de pesquisas sobre cursos on-line de pós-graduação em educação, apontando que os alunos identificaram vários benefícios, tais como: a conveniência de acesso, o aumento da quantidade e da intensidade de interação com os colegas, e maior acesso aos conhecimentos.

Além disso, também levanta o papel ativo do aluno na construção do conhecimento, reforçando a aprendizagem. Ao contrário da sala de aula tradicional, onde um aluno por vez expõe seus comentários, no ambiente on-line todos os alunos podem fazer comentários quando considerarem pertinente. Desta forma, "a participação ativa é exigida [do aluno] porque num ambiente textual é necessário fazer comentários para ser visto e estar presente" (Harasim et al, 2005), o que aumenta as interações entre 
alunos. Isso possibilita que várias discussões sejam realizadas ao mesmo tempo com maior grau de profundidade acerca dos temas debatidos, pois os estudantes têm mais tempo para pesquisar e formular respostas.

De acordo com Morin (2013), a formação acadêmica desde a escola até a universidade ensina a separar os objetos de seu contexto, para simplifica-los, e a separar as disciplinas umas das outras para não ter que relacioná-las. Essa fragmentação, ainda segundo o autor, é incapaz de captar o complexo. Por complexo, o mesmo autor define em sua obra Introdução ao Pensamento Complexo que "a complexidade é efetivamente o tecido de acontecimentos, ações, interações, retroações, determinações, acasos, que constituem nosso mundo fenomênico" (MORIN, 2005). Portanto, o PBL tem como desafio promover a pesquisa e o desenvolvimento alinhados ao conhecimento complexo, estratégia defendida por Pedro Demo (1997), a qual ele argumenta a favor de "formar a cidadania do pesquisador, à medida que aprende a argumentar, a trabalhar em equipe, a ouvir com atenção e a tratar posições contrárias com respeito".

Em tempo, aproveita-se a discussão de Pedro Demo em sua obra para justificar a utilização do termo interdisciplinaridade neste trabalho, em contraposição ao vocábulo "transdisciplinaridade", utilizado por Edgar Morin em suas publicações. Demo levanta a interpretação de "transdisciplinaridade" como a possibilidade de o intercâmbio disciplinar acarretar na a desfiguração das especialidades, equivocadamente. A opção por se utilizar o termo "interdisciplinaridade" é uma interpretação consonante à de Pedro Demo, que "representa a orquestração intrínseca das disciplinas, fazendo convergir seus pontos diversificados de origem. Trata-se de construir um texto único a várias mãos" (DEMO, 1997).

Portanto, como discorre também o autor,

$$
\begin{aligned}
& \text { tendo em vista que todo problema importante da sociedade é } \\
& \text { interdisciplinar, se quisermos ir além do mero estudo analítico dos } \\
& \text { problemas, ou seja, se quisermos construir soluções, não as } \\
& \text { encontramos jamais nas especializações, mas na abordagem } \\
& \text { globalizada. (DEMO, 1997) }
\end{aligned}
$$

Em suma, como observado por Garrossini et al (2012), a aprendizagem colaborativa abrange, dentre outras habilidades, a comunicação, o compartilhamento e a negociação. Desta forma, é imprescindível a existência de um ambiente de apoio à comunicação entre as equipes de projeto. Portanto, a Universidade de Brasília (UnB) se 
apresenta como um espaço acadêmico com potencialidade para planejar, implementar e disseminar o m-learning tanto aliado ao ensino presencial, como à EAD.

Com estas necessidades em mente, provou-se necessária a criação de um ambiente no qual todos os alunos tenham acesso a todas as informações do projeto, independentemente de qual etapa estejam trabalhando, visto que um dos maiores problemas apontados pelas pesquisas realizadas com os estudantes do projeto de coleta seletiva foi a falha na comunicação entre os colegas de projeto, o que resultava em confrontos e divergências de opiniões, inclusive dentro de grupos que estavam trabalhando nas mesmas etapas, pois não se sabia o andamento das tarefas, visto que havia monopólio de informações por parte dos líderes dos grupos menores, que também falhavam em se comunicar com os líderes dos grupos que estavam trabalhando em outras etapas dentro do mesmo projeto.

Desta forma, foi idealizado um aplicativo para auxiliar o gerenciamento colaborativo de projetos, principalmente em disciplinas que usam o PBL como base e têm muitos alunos. Com o estudo do m-learning integrado ao PBL, observou-se a potencialidade do uso de dispositivos móveis sem que o volume de trocas entre estudantes atrapalhasse no resgate de informações relevantes. 


\section{$2^{\circ}$ Capítulo: Análise contextual e metodológica com foco no ambiente de aprendizagem baseada em projetos para a educação superior}

Este segundo capítulo discorre sobre as necessidades de desenvolvimento dos projetos colaborativos a partir da análise do contexto do projeto para o desenvolvimento da coleta seletiva de materiais recicláveis e de um veículo elétrico para realizar esta atividade na Universidade de Brasília. Em seguida, são apresentados os requisitos para a concepção de espaços digitais que apoiem a comunicação e o registro de projetos colaborativos. Após a elaboração dos requisitos, os ambientes existentes e relevantes foram analisados quanto ao cumprimento destes. A partir desta análise, chegou-se à conclusão de que havia a necessidade da construção de um ambiente colaborativo para auxiliar a comunicação e o registro de projetos colaborativos.

Para facilitar o entendimento das etapas metodológicas do trabalho, foi elaborada uma linha do tempo gráfica, apresentada na Figura 1, que exibe a sequência de atividades realizadas, considerando o início das pesquisas, em 2011, passando pelo início deste trabalho de mestrado, em 2013, e encerrando-se em 2015, com a publicação deste trabalho, porém não de forma absoluta, pois há a possibilidade de contribuições e melhorias à solução planejada e desenvolvida de ambiente colaborativo. 


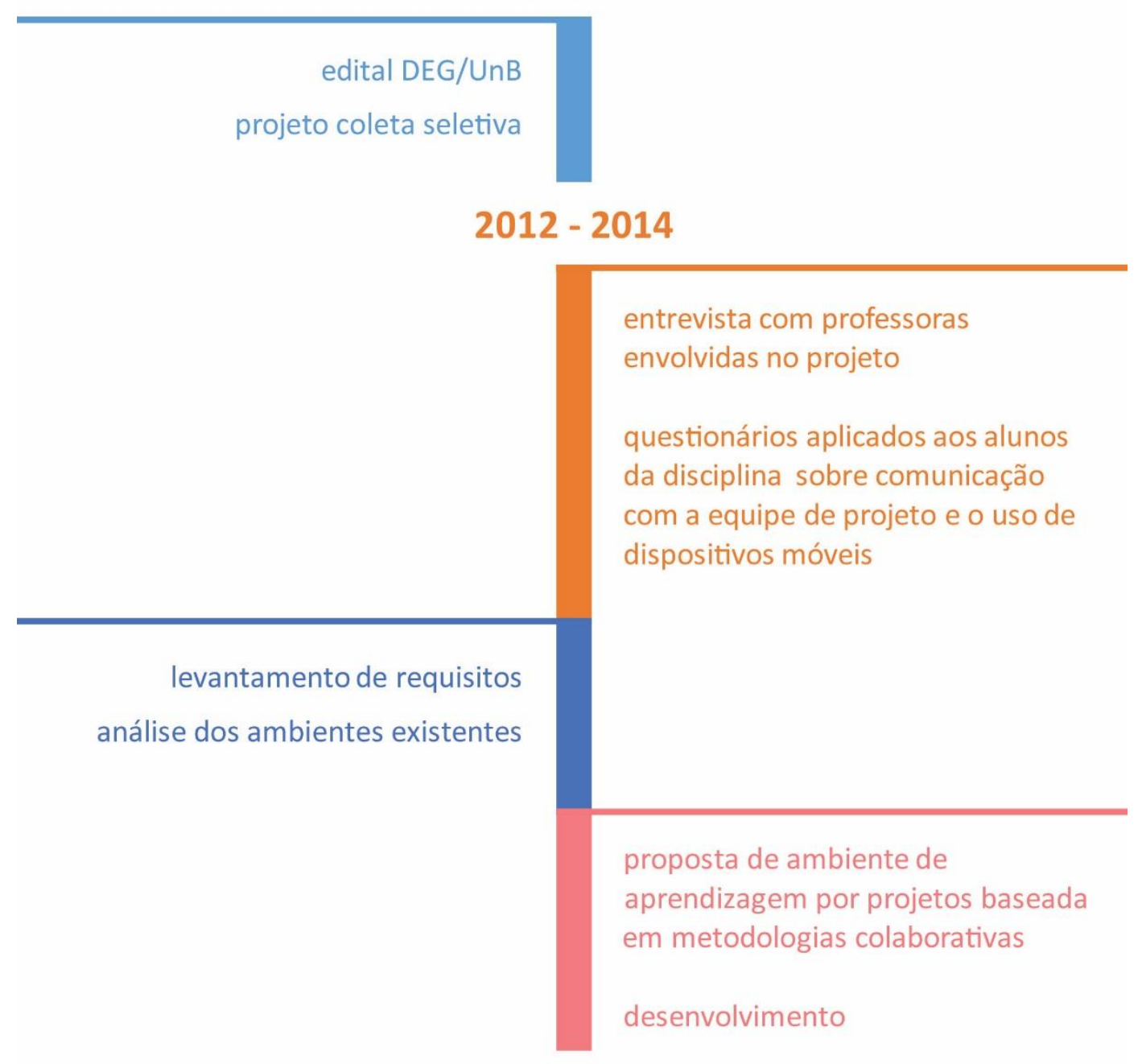

2015

continuação do desenvolvimento

validação e análise da solução planejada

Figura 1: Linha do tempo metodológica do trabalho

\subsection{Contextos e necessidades do desenvolvimento dos projetos colaborativos}

Foi formada uma equipe no Núcleo de Multimídia e Internet da UnB (NMI/UnB) para trabalhar no objeto do edital do DEG/UnB mencionado no capítulo anterior. O NMI é um laboratório interdisciplinar da Universidade de Brasília que atua desde 1999 na promoção de pesquisa, desenvolvimento e inovação, buscando integrar a academia, o 
governo, as empresas e a sociedade de forma a promover a participação aliada ao desenvolvimento social e tecnológico. O grupo para o desenvolvimento deste projeto era inicialmente composto pela coordenadora do projeto, a professora Daniela Garrossini, do departamento de Design, e seis alunos de graduação: quatro do departamento de Design, um da Computação e outro da Engenharia Mecatrônica; além do apoio de outros dois professores: uma da Comunicação e outro do Design.

Em 29 de fevereiro de 2012 a equipe entrevistou as professoras responsáveis pelo projeto de coleta seletiva, a professora Dianne Vianna e a professora Daniela Garrossini, com o objetivo de conhecer seu desenvolvimento e suas necessidades.

Elas falaram sobre como o projeto naquele momento contava com aproximadamente 30 alunos trabalhando na construção do veículo, divididos em três grandes grupos: Mecânica, Elétrica e Design. O Projeto Integrador é dividido em duas disciplinas: Projeto Integrador 1 e 2, sendo que o primeiro tem foco na administração do projeto e da equipe e o segundo no desenvolvimento, tendo como objetos de avaliação o Plano de Projeto, na primeira disciplina, e o Relatório Técnico, na segunda. Uma das professoras relatou que poucos alunos ficam no projeto após cursar as disciplinas, pois não conseguiam se motivar e aprofundar o desenvolvimento das atividades devido à realização de trabalhos pontuais, sem perspectiva concreta do produto final.

Como todas as áreas necessitavam constantemente do apoio das outras, sem a possibilidade de tomar decisões isoladas, pois estas afetavam diretamente o desenvolvimento dos outros grupos (VIANNA et al, 2011), os alunos organizaram-se a respeito de como e quais reuniões seriam conduzidas, chegando à conclusão de que deveriam haver reuniões semanais com toda a equipe envolvida na construção do veículo elétrico de forma a também ampliar o contato dos professores com toda a equipe.

Estas reuniões eram realizadas em horários que a maioria da equipe geral tinha disponibilidade, tentando conciliar aproximadamente trinta agendas, o que se provou um difícil feito. Ao mesmo tempo, também acharam necessário que houvesse uma reunião semanal, em outro dia da semana, entre os membros de cada subgrupo. As diferenças entre as reuniões estão descritas no Quadro 1. 
Quadro 1: Diferenças entre as reuniões das equipes do Projeto Integrador

\begin{tabular}{|c|c|c|}
\hline & Reunião Geral & Reuniões Técnicas (subgrupos) \\
\hline Participantes & $\begin{array}{l}\text { Equipe completa, incluindo } \\
\text { professores e alunos. }\end{array}$ & $\begin{array}{l}\text { Apenas integrantes de cada } \\
\text { equipe. }\end{array}$ \\
\hline Professores & Nem sempre participavam. & Nem sempre participavam. \\
\hline Pauta & $\begin{array}{l}\text { Atualização do andamento geral } \\
\text { do projeto com o mínimo de } \\
\text { detalhes técnicos, apenas o } \\
\text { necessário para compreensão } \\
\text { geral. }\end{array}$ & $\begin{array}{l}\text { Planejamento e execução de cada } \\
\text { etapa, ajustando cronograma e } \\
\text { atualizando a equipe sobre o } \\
\text { andamento individual das } \\
\text { atividades de cada membro. }\end{array}$ \\
\hline Atividades & $\begin{array}{l}\text { - Soluções para captação de } \\
\text { recursos financeiros; } \\
\text { - Organização de } \\
\text { minicursos internos; } \\
\text { - } \text { Distribuição de tarefas } \\
\text { - gerais para cada equipe; } \\
\text { - Anúncios de competições; } \\
\text { - Propostas para divulgação } \\
\text { do projeto. }\end{array}$ & $\begin{array}{l}\text { - Discussão do escopo da } \\
\text { etapa; } \\
\text { - Planejamento e ajuste do } \\
\text { cronograma; } \\
\text { - Distribuição de atividades } \\
\text { entre os membros da } \\
\text { equipe; } \\
\text { - Desenvolvimento de } \\
\text { tarefas. }\end{array}$ \\
\hline
\end{tabular}

Desta forma, os professores, por não terem disponibilidade de comparecer a todas as reuniões, se reuniam com os líderes de cada subgrupo, que os informavam do que foi debatido nas reuniões gerais e do que foi executado nas reuniões técnicas. Isso gerava descontentamento por parte do restante dos alunos, pois eles queriam que houvesse suporte também às atividades técnicas por parte dos professores. Além disso, uma das professoras comentou da dificuldade de avaliação do desempenho de cada aluno, de forma individual, o que dificultava na avaliação.

Além disso, a equipe de pesquisa perguntou às professoras como era realizada a organização dos documentos do projeto e a comunicação entre os alunos: os arquivos eram disponibilizados no Dropbox, um espaço de armazenamento em nuvem. Estes 
consistiam em relatórios técnicos, artigos, vídeos, arquivos de desenvolvimento e apresentações de slides, contatos da equipe, dentre outros. A comunicação era realizada presencialmente, nas reuniões ou por e-mail.

Ou seja, faltava comunicação horizontal entre a equipe e havia dificuldade em realizar reuniões presenciais nas quais todos estivessem presentes. Além disso, faltavam registros do desenvolvimento do projeto, faltava divulgação para o público externo e havia dificuldade para acompanhar o desenvolvimento de habilidades e competências individuais. Em resumo, “os processos de gestão, particularmente os de comunicação eram deficitários em relação à comunicação horizontalizada" (GARROSSINI et al, 2012).

Após a realização da entrevista, também se fez necessário construir e aplicar dois questionários aos estudantes: um com vistas a conhecer o perfil da equipe com relação ao uso de dispositivos móveis, pois observou-se que $m$-learning aliado ao PBL poderia ser utilizado para auxiliar o registro e a comunicação, como analisado no capítulo anterior; o outro tinha o objetivo de avaliar a percepção individual dos alunos quanto ao desenvolvimento do projeto e o relacionamento com a equipe.

Os instrumentos de pesquisa foram aplicados em abril de 2012, sendo que o primeiro teve 19 respostas e o segundo 16. A estrutura dos questionários e suas respostas estão disponíveis nos anexos de I a IV. Do primeiro instrumento, nove alunos eram do grupo de Elétrica e igual número era da equipe de Mecânica. Um aluno participava das duas equipes. No segundo não foi perguntada a equipe, mas sim o curso: dois alunos eram do Design, cinco de Engenharia Mecânica, quatro de Engenharia Elétrica, quatro de Mecatrônica e um de Computação.

O primeiro questionário, cuja estrutura encontra-se no Anexo III, era composto por uma sequência inicial de perguntas sobre o trabalho em equipe, seguida por uma avaliação com base na avaliação de desempenho $360^{\circ}$ (do inglês, 360-degree feedback), uma das ferramentas utilizadas na gestão de pessoas para a compreensão do desempenho de cada integrante da equipe sob a ótica combinada de cada um de seus membros. Neste questionário, os alunos avaliavam os outros colegas de equipe em relação à comunicação.

A partir das respostas obtidas, pode-se observar que, na percepção deles, toda a equipe participou do projeto, apesar de que alguns membros demonstram dificuldade 
em apresentar ideias, mas procuram agir frente a maioria das situações ocorridas, mesmo que não de forma imediata. Quando questionados sobre a organização das tarefas, materiais e documentos que utilizaram para a realização do projeto, estes marcaram que o grupo não chegou a se perder no trabalho, mas apresentou dificuldades em desenvolver meios de organizar suas atividades. Além disso, com relação à frequência, os alunos responderam que houveram faltas, sendo que algumas não foram justificadas.

\subsection{Houve organização das tarefas e materiais, documentos e outros que utilizaram} para realização de seu trabalho?

\begin{tabular}{|l|l|l|}
\hline $\begin{array}{l}\text { todos foram muito organizados } \\
\text { quanto ao controle e ao cuidado } \\
\text { nas atividades }\end{array}$ & 7 & $36.8 \%$ \\
\hline $\begin{array}{l}\text { não foram organizados, } \\
\text { perderam-se frequentemente na } \\
\text { execução de seu trabalho }\end{array}$ & 2 & $10.5 \%$ \\
\hline $\begin{array}{l}\text { não chegaram a se perder em seu } \\
\text { trabalho, mas apresentaram } \\
\text { dificuldades em desenvolver } \\
\text { meios de organizar suas } \\
\text { atividades }\end{array}$ & 10 & $52.6 \%$ \\
\hline
\end{tabular}

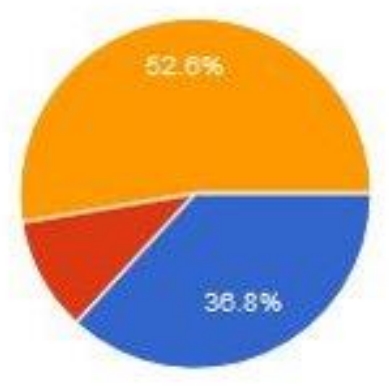

\subsection{Em relação à frequência no trabalho, como também às faltas justificadas:}

\begin{tabular}{|l|l|l|}
\hline $\begin{array}{l}\text { Raramente faltaram. } \\
\text { Quando isto ocorreu foi por } \\
\text { motivo justo e autorizado. }\end{array}$ & 6 & $31.6 \%$ \\
\hline $\begin{array}{l}\text { Houveram faltas ocasionais, } \\
\text { sendo que algumas não } \\
\text { foram justificadas. }\end{array}$ & 11 & $57.9 \%$ \\
\hline $\begin{array}{l}\text { Faltaram frequentemente } \\
\text { sem justificativas. }\end{array}$ & 2 & $10.5 \%$ \\
\hline
\end{tabular}

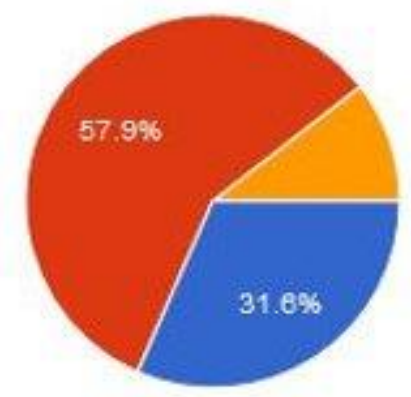

Figura 2: Respostas às questões sobre organização do projeto e frequência às reuniões

De maneira geral, os estudantes marcaram que os colegas de projeto colaboraram constantemente na resolução de problemas e que desenvolveram bem suas atividades, sendo que alguns também apresentaram facilidade em estabelecer contatos. 
Quadro 2: Soma das respostas obtidas na avaliação $360^{\circ}$ obtida por meio do Questionário 1

\begin{tabular}{|l|r|}
\hline Apresentou acentuada dificuldade em se relacionar com as pessoas & 1 \\
\hline Apresentou facilidade em estabelecer contatos & 35 \\
\hline Colaborou constantemente na resolução de problemas & 53 \\
\hline Desenvolveu bem suas atividades & 38 \\
\hline Necessitou orientação constante para melhorar seu relacionamento & 3 \\
\hline
\end{tabular}

Desta forma, pôde-se perceber a partir da aplicação do primeiro questionário que a percepção individual dos alunos os leva a crer que apesar de todos aparentemente realizarem bem suas atividades e colaborarem para a resolução de problemas, a proatividade dos colegas não é visível, somada ao fato de que nem todos os membros da equipe demonstram suas ideias. Além disso, a organização das atividades e dos arquivos necessários para a realização destas não é ideal. Tais dificuldades expressadas têm correlação próxima com o problema observado de comunicação entre a equipe e de registro das atividades.

A partir da aplicação do segundo questionário, foram obtidos os seguintes dados: à época, ou seja, em 2012, $81 \%$ dos estudantes do projeto possuíam smartphone e $13 \%$ tinham tablet. Com relação ao sistema operacional destes dispositivos, $31 \%$ eram Android e o mesmo percentual era iOS. Além disso, a maior parte dos estudantes tinha plano de dados $3 \mathrm{G}$ no dispositivo que mais utilizava.

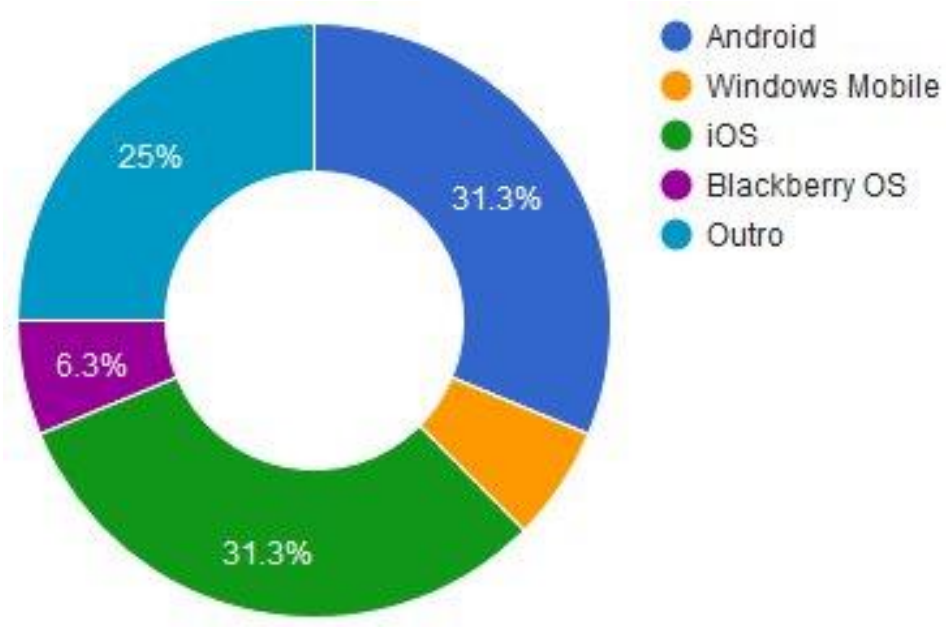

Figura 3: Sistemas operacionais utilizados pelos estudantes do Projeto Integrador no dispositivo móvel que mais utilizavam 
Quando perguntados sobre as principais funções do dispositivo móvel em seu diaa-dia, a maior parte dos estudantes respondeu que usava o telefone para fazer ligações e receber e enviar mensagens de texto. Além disso, também usavam o dispositivo para ler e-mails, tirar fotos e acessar a internet. Com relação a mensagens instantâneas, os aplicativos mais utilizados eram o Whatsapp e o Skype. Já em relação ao compartilhamento de arquivos, $63 \%$ utilizava o Dropbox.

Por fim, $25 \%$ dos estudantes contava com 8GB de espaço no dispositivo móvel e $19 \%$ contava com 16GB. Em relação à autonomia da bateria, 32\% respondeu que dura de 10 a 12 horas e $25 \%$ respondeu que dura mais do que 20 horas.

A partir da aplicação deste segundo questionário o poder aquisitivo e os avanços tecnológicos avançaram consideravelmente, apesar de terem se passado apenas três anos desde então. À época, um número notável de alunos na universidade já dispunha de smartphones, o que viabilizava a aplicação do m-learning em sala de aula. Sobre o sistema operacional (SO) dos dispositivos móveis, o percentual de aparelhos com iOS e Android era o mesmo, ou seja, a escolha de se produzir um aplicativo para um sistema ou outro se daria pela facilidade de desenvolvimento, por questões econômicas e pela acessibilidade. Nesse sentido, o Android se mostra como um SO mais democrático, cujos aplicativos têm o código baseado na linguagem Java, o hardware, ou seja, os dispositivos móveis têm preços mais acessíveis que os da Apple, e a distribuição na loja de aplicativos, a Play Store, é mais simplificada e economicamente viável, além de permitir que os aplicativos não sejam necessariamente ser distribuídos por ela, podendo ser transferidos como arquivos de um celular para outro, ou de um computador para o celular. Os estudantes também já eram familiarizados com a troca de mensagens e arquivos por meio de dispositivos móveis, o que facilita a futura utilização de aplicativos voltados para o gerenciamento de projetos colaborativos.

Com relação a aspectos de hardware, o espaço dos telefones é limitado, mas caso os arquivos sejam armazenados em nuvem, permitindo ao usuário manter em seu telefone para visualização off-line apenas os arquivos que mais lhe forem importantes, o tamanho da memória do aparelho deixa de ser um fator tão importante. Sobre a duração da bateria, se carregado antes de o aluno sair para a universidade, é possível utilizar o dispositivo para registrar o desenvolvimento do projeto em tempo real, mas ainda assim não é possível o uso intenso dos recursos do dispositivo, pois gravar vídeos, tirar várias 
fotos e utilizar-se de redes móveis e/ou sem fio por longos períodos de tempo costuma drenar a bateria rapidamente.

Ainda sobre o contexto da disciplina, após a realização da entrevista e da aplicação dos questionários, o Projeto Integrador aumentou em escopo e número de alunos, pois passou a englobar, além do planejamento e da construção de um veículo elétrico, a concepção das etapas de triagem e descarte de resíduos. O projeto então ficou constituído pelas equipes representadas na Figura 4, alocadas em subgrupos responsáveis por cada etapa.
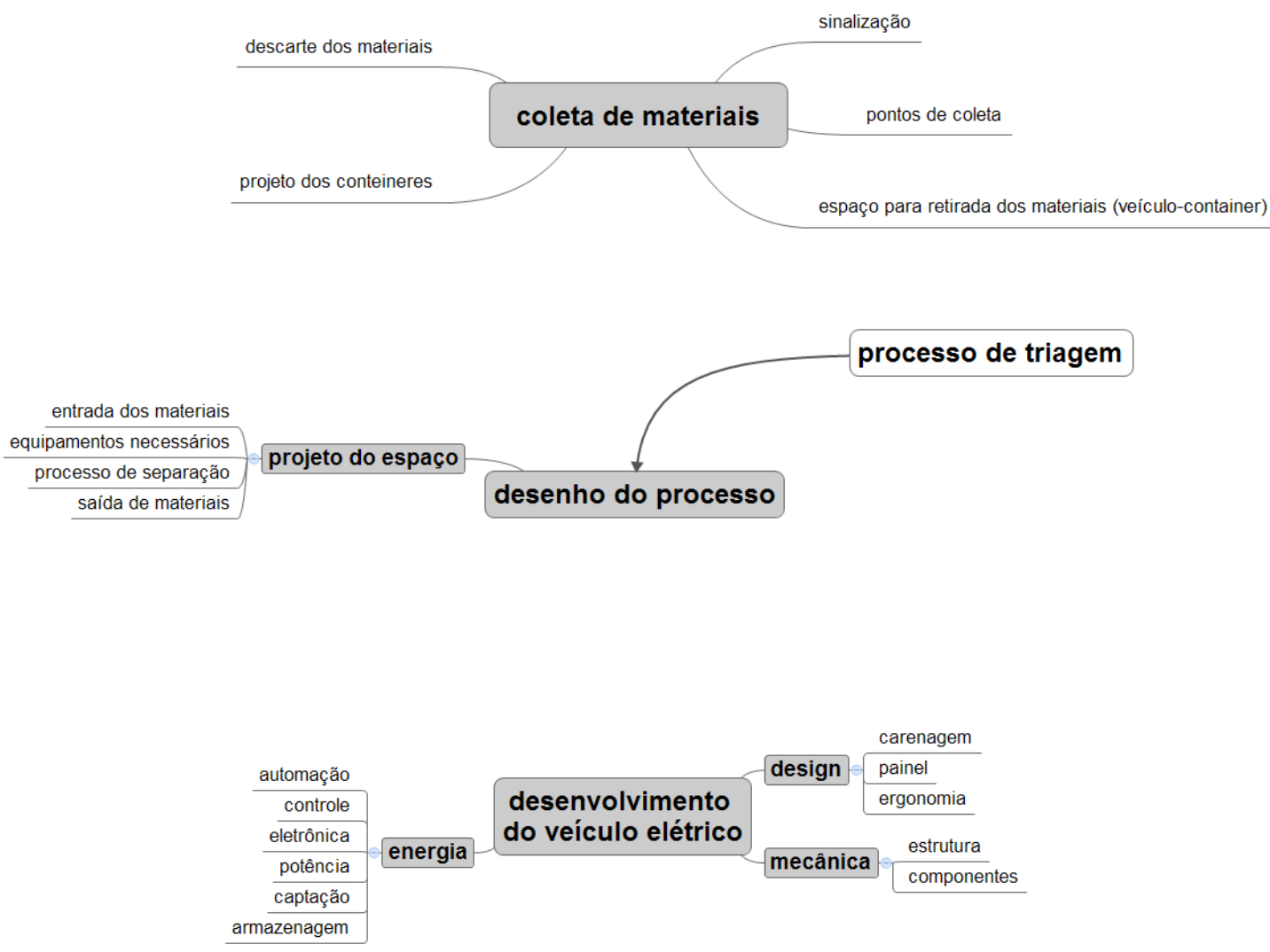

Figura 4: Representação das equipes do Projeto Integrador

O projeto passou então a ser composto por três grandes núcleos interdependentes, mas que continham seus próprios subgrupos, combinando os alunos das disciplinas do Projeto Integrador, de coordenação da professora Dianne Vianna do Departamento de Engenharia Mecânica, e de Metodologia do Projeto, de coordenação da professora Daniela Garrossini, do Departamento de Design. Com uma equipe tão numerosa e interdisciplinar, contando com aproximadamente sessenta alunos, aumentaram os 
desafios relativos à comunicação e ao registro das atividades, tornando ainda mais necessário o desenvolvimento de uma solução de comunicação para auxiliar no desenvolvimento deste projeto colaborativo.

\subsection{Requisitos para a concepção de espaços digitais que que apoiem a comunicação e o registro de projetos colaborativos}

Com base nos estudos bibliográficos e documentais empreendidos, além de pesquisas empíricas e das análises da entrevista e dos questionários da seção anterior, foram levantados requisitos para ambientes colaborativos com base digital.

Ao pensar os requisitos, a equipe levou em consideração as necessidades observadas no projeto do veículo elétrico, além das próprias experiências de trabalho em grupo dentro e fora da Universidade, pois percebeu-se que que as demandas de um projeto desenvolvido em PBL são similares às de projetos desenvolvidos tanto dentro quanto fora de sala de aula, possibilitando o uso do aplicativo não apenas pelos alunos em classes que utilizam o PBL, mas também em outros projetos dentro e fora da UnB.

Observou-se que, para empreender um projeto colaborativo, o ambiente de gestão e desenvolvimento deste tipo de projeto deve contar com as funcionalidades descritas no Quadro 2.

Quadro 3: Requisitos necessários a um ambiente para desenvolvimento e gestão de projetos colaborativos

\begin{tabular}{|l|l|}
\hline Calendário e lista de tarefas & $\begin{array}{l}\text { É necessário que o membro da equipe de projeto } \\
\text { visualize as etapas nas quais está inserido, } \\
\text { possibilitando que ele se organize para executar as } \\
\text { tarefas planejadas ao mesmo tempo que tem } \\
\text { conhecimento de todas as etapas, caso deseje, } \\
\text { identificando quem são os colegas responsáveis e o } \\
\text { andamento do projeto. O calendário também } \\
\text { possibilita a criação de eventos e reuniões em um } \\
\text { espaço visível a todos os integrantes do projeto. }\end{array}$ \\
\hline Compartilhamento de arquivos & $\begin{array}{l}\text { Durante o desenvolvimento do projeto é necessário } \\
\text { compartilhar diversos tipos de dados, dentre } \\
\text { documentos, apresentações, planilhas, links, }\end{array}$ \\
\hline
\end{tabular}




\begin{tabular}{|c|c|}
\hline & $\begin{array}{l}\text { imagens, vídeos e fotos, por exemplo. É comum aos } \\
\text { projetos colaborativos que arquivos importantes se } \\
\text { percam em e-mails e pendrives. Esse requisito leva } \\
\text { em consideração que o membro da equipe de } \\
\text { projeto possa carregar e baixar arquivos a partir de } \\
\text { um servidor em nuvem, preferencialmente } \\
\text { possibilitando que este possa capturar áudio, fotos e } \\
\text { vídeos em seu dispositivo, compartilhando-os de } \\
\text { forma integrada, sem a necessidade de sair do } \\
\text { aplicativo. }\end{array}$ \\
\hline Lista de contatos & $\begin{array}{l}\text { Toda a equipe de projeto deve ter à sua disposição a } \\
\text { listagem dos integrantes da equipe, além as } \\
\text { informações de contato destes, permitindo-os } \\
\text { contatá-los por e-mail, telefone ou por mensagens } \\
\text { instantâneas. }\end{array}$ \\
\hline Linha do tempo & $\begin{array}{l}\text { É necessário agrupar todas as informações do } \\
\text { projeto em um único local, em ordem cronológica, } \\
\text { tais como nome do projeto, tarefas adicionadas, } \\
\text { tarefas realizadas, eventos criados, compromissos } \\
\text { próximos e novos documentos compartilhados, por } \\
\text { exemplo. A linha do tempo também deve permitir } \\
\text { que os membros do projeto comentem todos os } \\
\text { acontecimentos, criando assim um espaço de } \\
\text { discussão e colaboração. }\end{array}$ \\
\hline Notificações & $\begin{array}{l}\text { Faz-se necessária a integração do ambiente com a } \\
\text { central de notificações do dispositivo móvel para } \\
\text { possibilitar uma comunicação efetiva entre os } \\
\text { participantes do projeto e garantir que o usuário } \\
\text { fique ciente de reuniões e comunicados importantes } \\
\text { mesmo quando não esteja com o aplicativo aberto. }\end{array}$ \\
\hline
\end{tabular}


Dentro deste ambiente também foi verificada a necessidade de agrupamento de informações e funções relevantes ao projeto, descritas no quadro a seguir:

Quadro 4: Descrição das informações a serem agrupadas em ambientes para o gerenciamento colaborativo de projetos

\begin{tabular}{|l|l|}
\hline Arquivos & $\begin{array}{l}\text { Troca e registro dos arquivos compartilhados entre a equipe, como } \\
\text { textos, fotografias e vídeos. }\end{array}$ \\
\hline Tarefas & $\begin{array}{l}\text { Possibilidade de atribuir, registrar e acompanhar as tarefas para cada } \\
\text { integrante da equipe. Essas ações podem ser realizadas de qualquer } \\
\text { aluno para qualquer aluno. }\end{array}$ \\
\hline Calendário & $\begin{array}{l}\text { Visualização de datas de realização de tarefas e de eventos relevantes } \\
\text { ao projeto em um calendário que podem ser marcos do projeto, por } \\
\text { exemplo. }\end{array}$ \\
\hline Fóruns & $\begin{array}{l}\text { Espaços para discussão geral de assuntos relacionados ao projeto e } \\
\text { possibilidade de inserção de comentários de outros colegas. }\end{array}$ \\
\hline Subgrupos & $\begin{array}{l}\text { Além da possibilidade de as informações acima serem agrupadas para } \\
\text { todo o projeto, elas também podem ser filtradas por etapa, sendo que } \\
\text { cada uma é composta por um grupo de alunos e dos líderes que estão } \\
\text { trabalhando nelas. Desta forma, cada aluno opta por visualizar o } \\
\text { projeto por inteiro, ou apenas os arquivos da etapa na qual está } \\
\text { trabalhando, dependendo da necessidade atual. }\end{array}$ \\
\hline
\end{tabular}

Expostas as funcionalidades e os agrupamentos de informação das tabelas anteriores, é visível a necessidade destes aspectos serem considerados na construção de um ambiente para o gerenciamento e registro de projetos colaborativos, buscando auxiliar na realização de atividades desenvolvidas tanto presencialmente quanto à distância, permitindo aos integrantes destes projetos ter acesso a todas as informações que julgar relevantes para o desenvolvimento de suas atividades. 


\subsection{Análise das soluções para o gerenciamento de projetos colaborativos}

Após o entendimento dos requisitos necessários para um ambiente de gerenciamento de projetos colaborativos, foram empreendidas análises com o objetivo de compreender aspectos importantes para o gerenciamento de projetos colaborativos.

Fez-se necessária uma pesquisa para levantar ambientes com foco específico em gestão colaborativa de forma a observar soluções para problemas encontrados no desenvolvimento de projetos, especialmente os desenvolvidos em disciplinas que utilizam o PBL como base, de maneira a fortalecer os requisitos para o desenvolvimento do aplicativo.

Para isso, foram pesquisadas e listadas várias aplicações online com foco no gerenciamento de projetos. Dentre elas, foram selecionadas algumas cujo formato era de ambientes que possibilitavam a interação entre os integrantes do projeto. Filtrando ainda mais, foram selecionadas as que facilitavam o desenvolvimento de projetos colaborativos, permitindo a comunicação entre os participantes.

Desta forma, a partir dos requisitos levantados, que agrupam informações semelhantes com o objetivo de simplificar a posterior recuperação destes dados no momento que o usuário desejar, foram estabelecidas questões norteadoras para a nova análise das aplicações:

Quadro 5: Questões norteadoras para a análise dos ambientes

\begin{tabular}{|l|l|}
\hline Fóruns & $\begin{array}{l}\text { Como é realizada a comunicação entre os membros da } \\
\text { equipe? }\end{array}$ \\
\hline Tarefas & Como as tarefas são distribuídas e registradas? \\
\hline Cronograma & $\begin{array}{l}\text { Como são registrados e acompanhados os marcos e datas } \\
\text { importantes? }\end{array}$ \\
\hline Arquivos & Como é o gerenciamento de arquivos relativos ao projeto? \\
\hline Linha do tempo & Como essas informações anteriores são exibidas ao usuário? \\
\hline
\end{tabular}


Os ambientes colaborativos foram estudados a partir destas perguntas, com o objetivo de validar as características do Tiê e aprimorá-las.

Foram selecionados três modelos de ambientes colaborativos utilizados pelo mercado para o gerenciamento de projetos colaborativos: Basecamp, Trello e Flow. O primeiro ainda é referência nesta área, e por isso foi o único da análise anterior a ser novamente listado. Os outros dois surgiram posteriormente: o Trello foi lançado em setembro de 2011, mas não era popular no momento da primeira análise; já o Flow foi divulgado em 2011 como uma ferramenta para a comunicação interna do andamento dos projetos da empresa Treehouse, que não tem a figura de gerentes no seu corpo administrativo.

As aplicações foram analisadas tanto pela pesquisa do conteúdo divulgado em seus websites e lojas de aplicativos, quanto por meio do teste de suas funcionalidades, no caso das aplicações Trello e Basecamp.

\section{Flow}

O Flow é definido pelo seu criador, Ryan Carson (2013), como um ambiente web que tem como foco a comunicação sobre projetos em andamento na Treehouse, uma empresa sediada nos Estados Unidos que oferece cursos online relativos ao desenvolvimento de sites e aplicações para computadores e dispositivos móveis. Esse ambiente foi planejado para que qualquer colaborador da empresa pudesse propor ideias de projetos que pudessem ser visualizadas pelo restante da empresa. O Flow surgiu a partir de necessidades reais da Treehouse, um empreendimento gerido de forma colaborativa, ou seja, não existe a figura de um gerente para decidir quais ideias serão implementadas ou não: elas são decididas pela maioria. Além disso, observava-se que, anteriormente ao uso do ambiente, a troca de informação concentrada em e-mails individuais era um problema, pois nem todos na empresa eram informados de decisões que poderiam interessá-los.

Seguem abaixo os resultados da análise do Flow de acordo com o agrupamento da informação:

\section{a) Fóruns}

Ao questionar a comunicação entre os membros da equipe, foi observado que o Flow tem foco na atualização dos projetos. Para a troca de mensagens entre a 
equipe, a Treehouse utiliza um app específico denominado HipChat e tem um ambiente de discussão similar a um fórum chamado "Convoy".

A troca de mensagens só é realizada no Flow quando um usuário propõe um projeto, pois nesse momento é criado uma espécie de fórum de discussão no qual outros usuários podem criar fóruns caso se interessem pelo projeto e queiram discutir a viabilidade da sua execução. Desta maneira, todas as pessoas que manifestaram seu interesse em participar e foram adicionadas à equipe do projeto são avisadas sobre novas postagens no fórum para se manterem atualizadas quanto ao andamento das atividades.

\section{b) Tarefas}

Ao questionar como as tarefas são distribuídas, percebeu-se que os usuários apenas registram as tarefas executadas no Flow, na área de "Status Update" (Atualização do status, em tradução livre). As tarefas já foram designadas anteriormente em reuniões presenciais ou outra ferramenta escolhida pela equipe, provavelmente o Convoy. Ao criar o Flow, Carson pensou apenas em resolver o problema de comunicação, pois acredita que as ferramentas já existentes de gerenciamento de projetos são adequadas às necessidades da sua empresa. A forma como o registro das tarefas realizadas é exibido pode ser visualizada na Figura 5. 


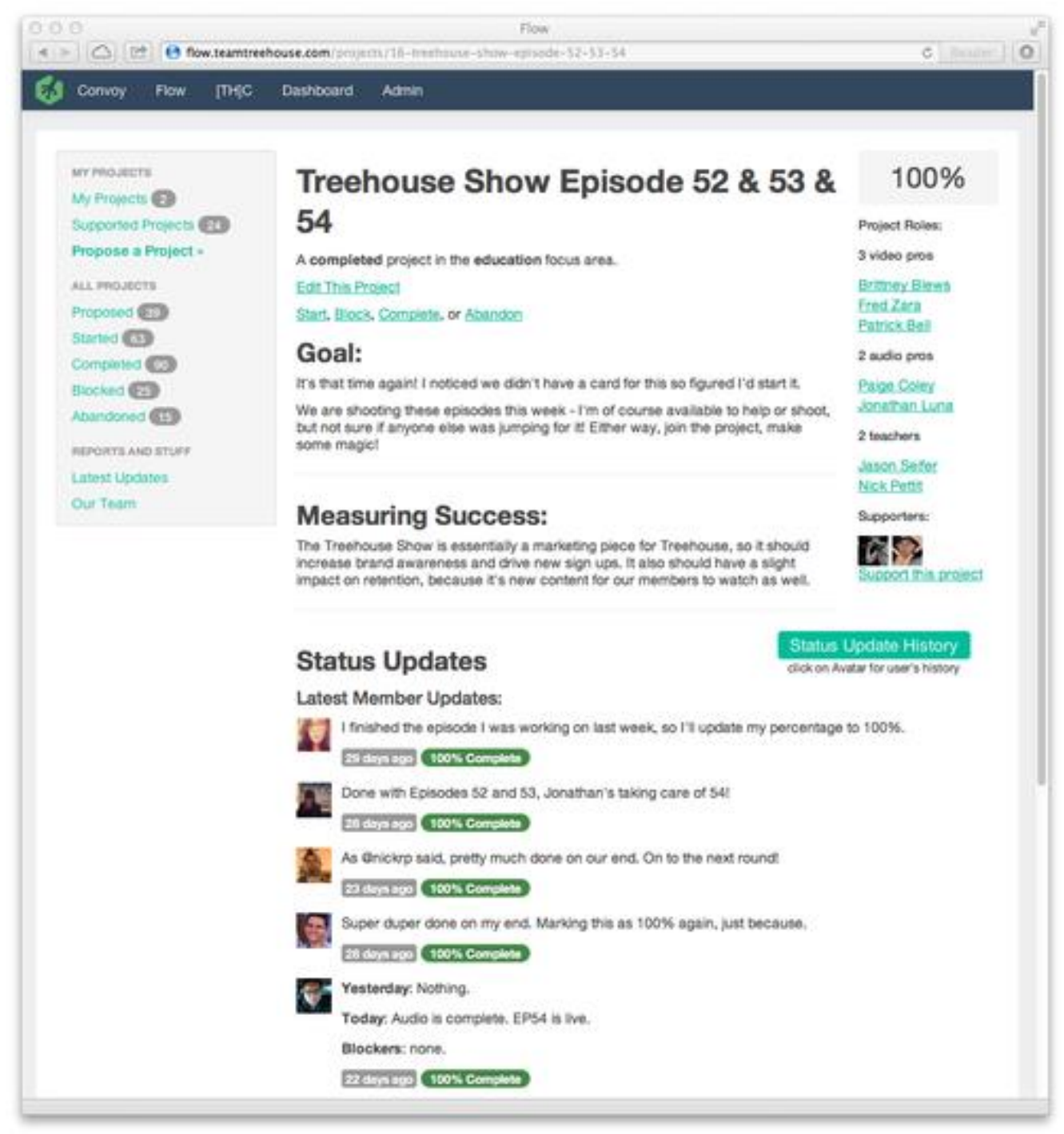

Figura 5: Ambiente de atualização do andamento do projeto no Flow.

Disponível em: <http://ryancarson.com/post/61606695537/how-to-set-priorities-create-budgets-and-do>

Apesar disso, a empresa solicita a seus funcionários que atualizem o ambiente todos os dias com as tarefas realizadas. Desta forma, qualquer pessoa interessada pode visitar a página do projeto no Flow e se inteirar do progresso das atividades, sem a necessidade de requisitar informações aos integrantes.

\section{c) Cronograma}

Como são registrados e acompanhados os marcos e datas importantes? Não há uma visualização de eventos futuros, já que o gerenciamento do projeto é realizado externamente ao Flow. As informações postadas pela equipe normalmente são relativas ao que foi executado no dia. Alguns usuários também 
postam ocasionalmente sobre atividades que desejam executar, mas não é uma exigência do ambiente.

\section{d) Arquivos}

Os arquivos relativos ao projeto não são armazenados no Flow. O ambiente não apresenta esta funcionalidade.

\section{e) Linha do tempo}

Como essas informações anteriores são exibidas ao usuário? O ambiente do Flow apresenta uma coluna na lateral esquerda que mostra os projetos de iniciativa do usuário, os projetos apoiados por ele e um link para propor um novo projeto. Além disso, ele permite ao usuário navegar por todos os projetos na plataforma, dividindo-os por: propostos, iniciados, completados, bloqueados e abandonados. O Flow é um ambiente fechado a usuários externos e Ryan Carson, ao explicar sua plataforma, não falou sobre essas classificações de projetos.

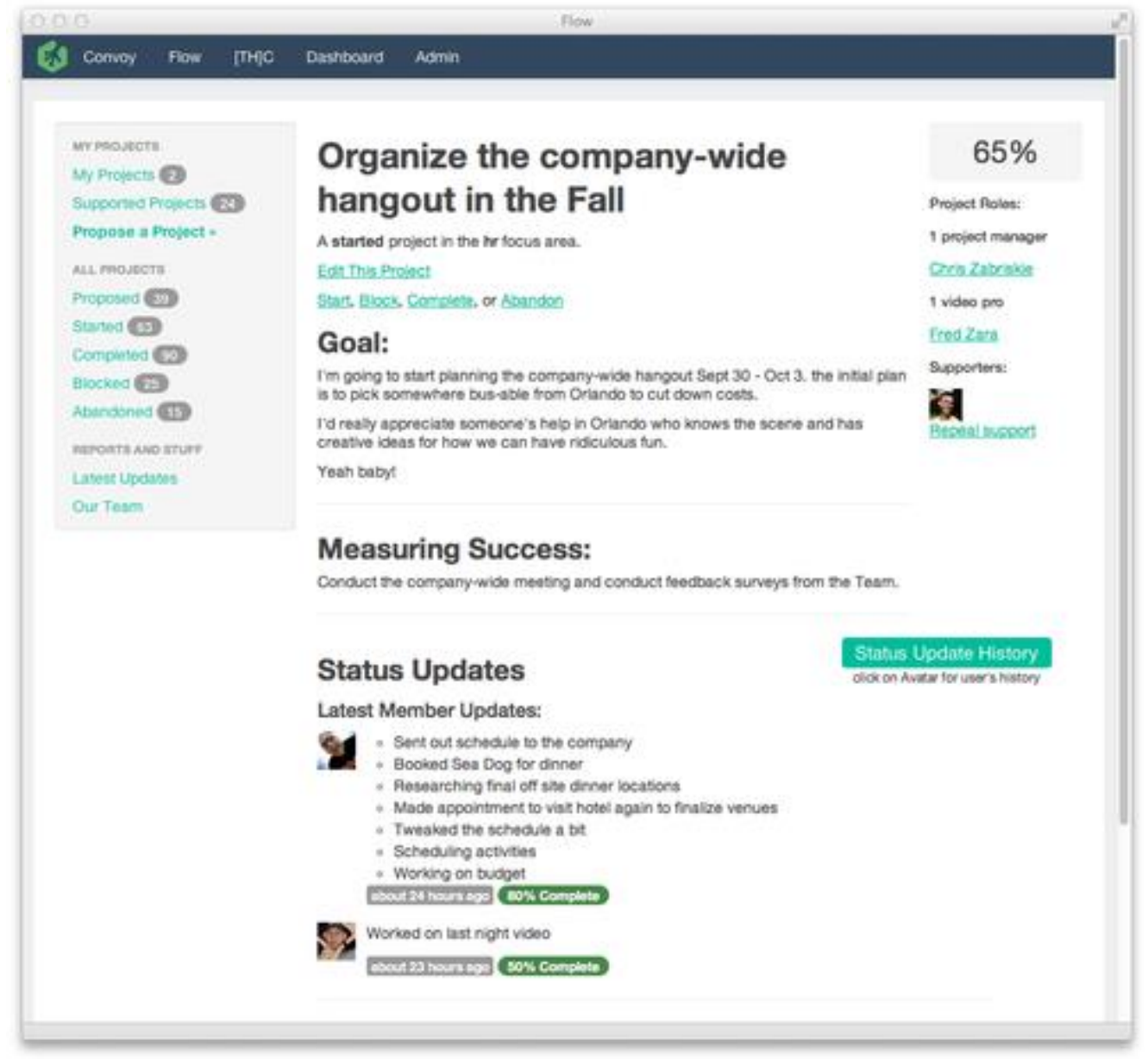

Figura 6: Exemplo de página de projeto dentro do Flow.

Disponível em: 〈http://ryancarson.com/post/61606695537/how-to-set-priorities-create-budgets-and-do〉 
Como também observado na imagem acima, há uma coluna à direita que apresenta a porcentagem realizada do projeto e lista a equipe e os papeis de cada membro.

No centro da página, podem ser observados o título do projeto, uma pequena descrição deste e links para as seguintes ações: editar o projeto ou marcálo como iniciado, bloqueado, completo ou abandonado. Além disso, há destaque para as informações sobre a meta do projeto e dos indicadores de sucesso.

Abaixo destas informações encontra-se um resumo das últimas atualizações do projeto, como postadas por cada usuário responsável pela tarefa, indicando que horas a postagem foi realizada e qual o percentual de conclusão da tarefa. À direita está um botão que leva o usuário a uma tela contendo todas as atualizações do projeto. Abaixo deste botão, há uma informação de que ao clicar na imagem de perfil de um membro da equipe do projeto, é exibido todo o histórico de atualizações de projeto daquela pessoa.

A partir da análise do Flow é possível observar que a Treehouse divide os ambientes de projeto em três: o HipChat é o ambiente no qual ocorrem as trocas de mensagens instantâneas, o Convoy é onde se localizam os registros de informações sobre o planejamento do projeto e, por último, o Flow é o ambiente no qual se localiza a lista dos projetos, inclusive os que estão na fase de proposta e os que já finalizaram ou foram cancelados. Este último é o local onde os usuários atualizam diariamente as tarefas realizadas e o progresso total em relação ao projeto.

O Flow é um ambiente que permite a atualização simples e colaborativa dos projetos, permitindo acesso transparente ao que foi realizado. Todavia, a Treehouse opta por separar os diferentes grupos de informação em diferentes ferramentas e o ambiente analisado não é disponível ao público geral, restringindo-se ao uso interno pelos colaboradores da empresa.

\section{Basecamp}

O Basecamp se define como auxiliador no processo de gerenciamento de projetos e colaboração, registrando atividades, produção, decisões e comunicação entre os membros das equipes de projeto em torno de um objetivo em comum: finalizar um 
projeto de forma colaborativa. Com mais de 10 anos de existência, sua proposta é manter todos os projetos, listas de tarefas, documentos, decisões, feedbacks e equipes juntos, no mesmo ambiente. Seu funcionamento é em nuvem, ou seja, os dados do projeto podem ser acessados por qualquer usuário, em qualquer dispositivo, tanto em computadores pessoais, na web, quanto em tablets e smartphones, com aplicativos específicos para estas versões.

Since 2004, hundreds of thousands of companies have used Basecamp to manage over $8,000,000$ projects. Basecamp is the world's most popular cloud-based project management and collaboration app.

\section{decisions feedback team}

Figura 7: Página inicial do Basecamp em 2012, listando as informações agrupadas pelo ambiente. Disponível em: <http://basecamp.com>.

Ao criar um projeto, o usuário o nomeia e tem a opção de inserir uma descrição. Neste momento ele também já pode digitar os e-mails das pessoas a serem convidadas para o projeto (o que pode ser feito posteriormente também). As mesmas pessoas podem ser adicionadas em mais de um projeto.

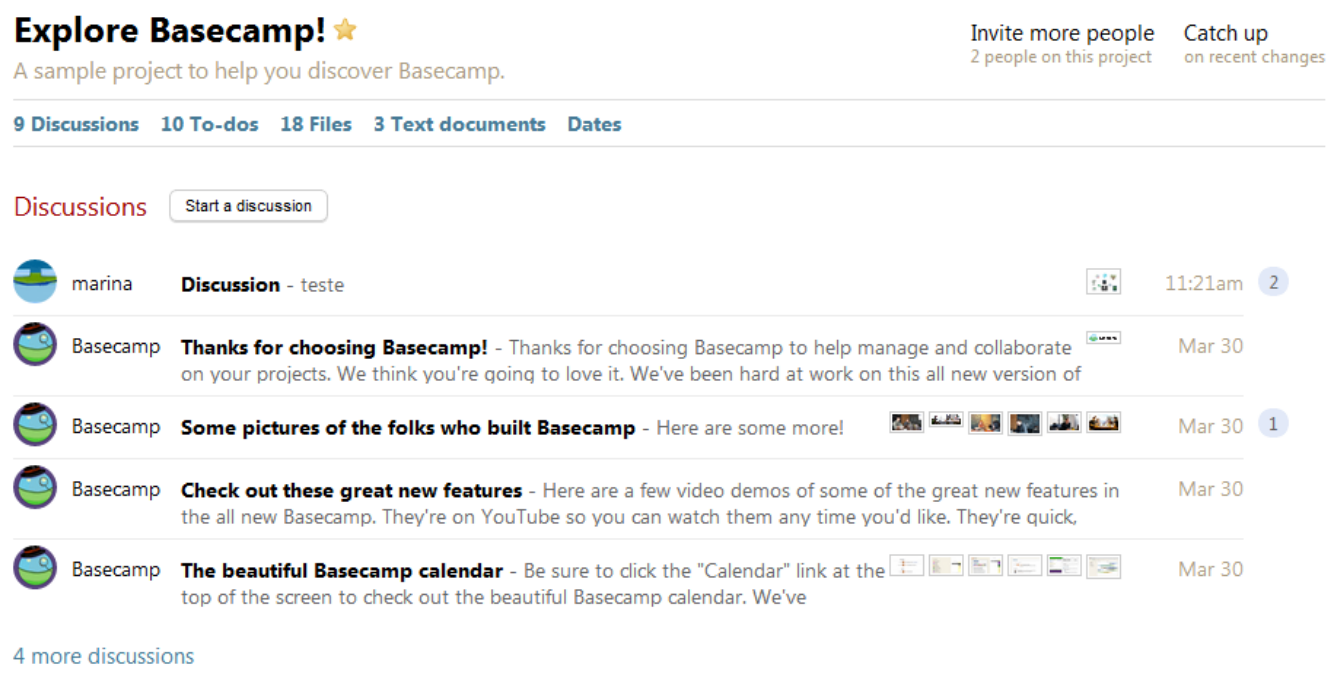

Figura 8: Exemplo de ambiente de projeto no Basecamp.

Disponível em: <http://basecamp.com>. 
O ambiente de projeto apresenta inicialmente as discussões entre usuários, como uma espécie de fórum. Outras opções de visualização são de listas de tarefas, arquivos, documentos de textos e datas.

Seguem abaixo os resultados da análise do Basecamp de acordo com o agrupamento da informação:

\section{a) Fóruns}

$\mathrm{Na}$ área de discussões há uma lista das discussões mais recentes, com um link abaixo para a visualização integral da lista, indicando quantas discussões existem além das já apresentadas, como visto anteriormente na Figura 8. Cada discussão é exibida junto ao nome e à imagem de perfil de quem a iniciou, constando também a data de criação, quantas mensagens há ao todo e qual a data do último comentário (ou qual o horário, se este foi realizado no mesmo dia que o usuário está vendo). Dentro do fórum de discussão, cada comentário pode ser feito tanto por texto, quanto por vídeo, imagem, ou pela combinação dos dois, sendo que ao final da página há um histórico das alterações da página.

\section{b) Tarefas}

$\mathrm{Na}$ área de listas de tarefas, há espaço para listas diferentes, com tarefas diferentes, além da opção de se adicionar uma nova tarefa, como pode ser visualizado na figura a seguir.

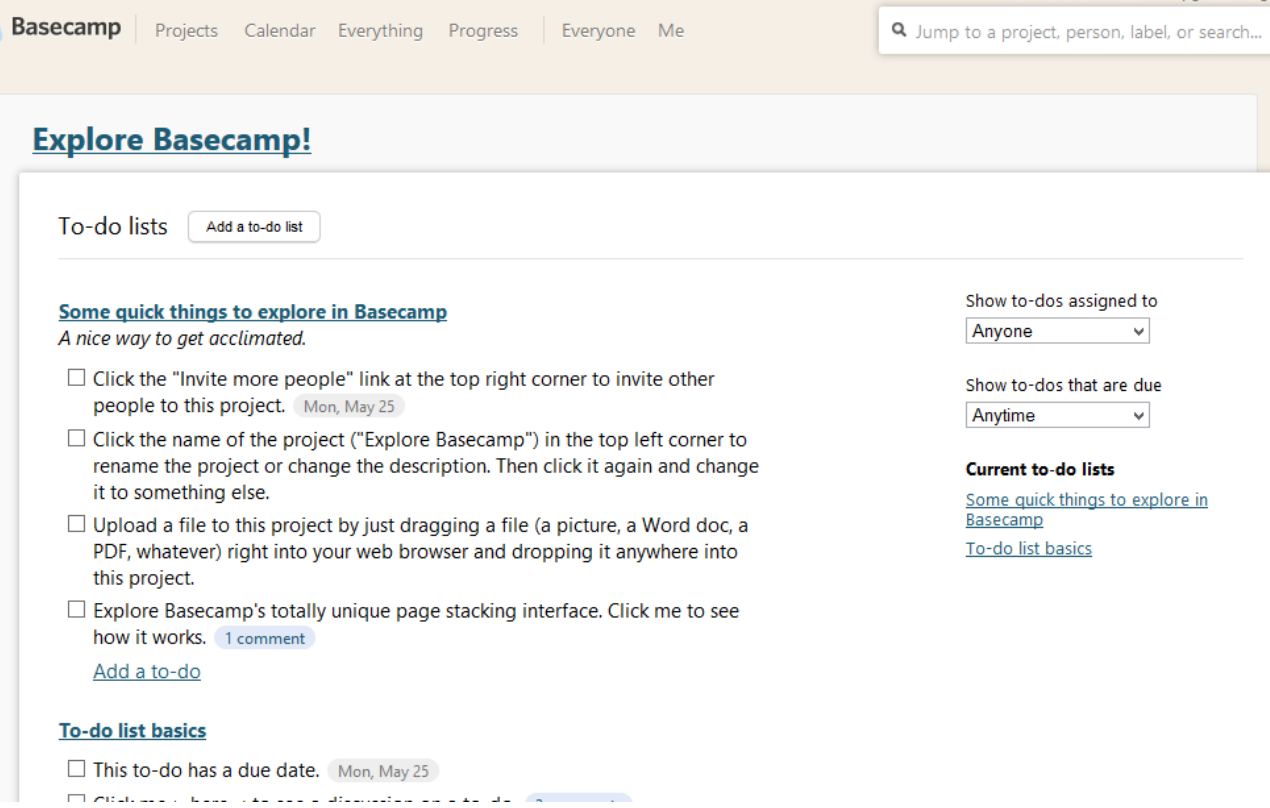

Figura 9: Exemplo de ambiente de tarefas no Basecamp.

Disponível em: <http://basecamp.com>. 
Em cada tarefa também podem ser feitos comentários, abrindo-se uma nova página para cada um deles. Na página principal, é exibido um campo para atualização da tarefa quanto à sua realização ou não, qual o nome da tarefa, quantos comentários ela tem, qual a data-limite para o término e quem é responsável por ela. Ao final, aparece um link para visualizar todas as tarefas que já foram realizadas.

No menu lateral esquerdo há opção de filtrar a lista de tarefas por responsável ou pela data-limite de realização da tarefa. Além disso, há um atalho para todos os grupos de tarefas em atividade.

\section{c) Cronograma}

$\mathrm{Na}$ área de eventos, o usuário consegue visualizar e incluir datas importantes para o projeto. A visualização padrão é de seis semanas.

Basecamp Projects Calendar Everything Progress Everyone Me Q Jump to a project, person, label, or search...

Explore Basecamp!

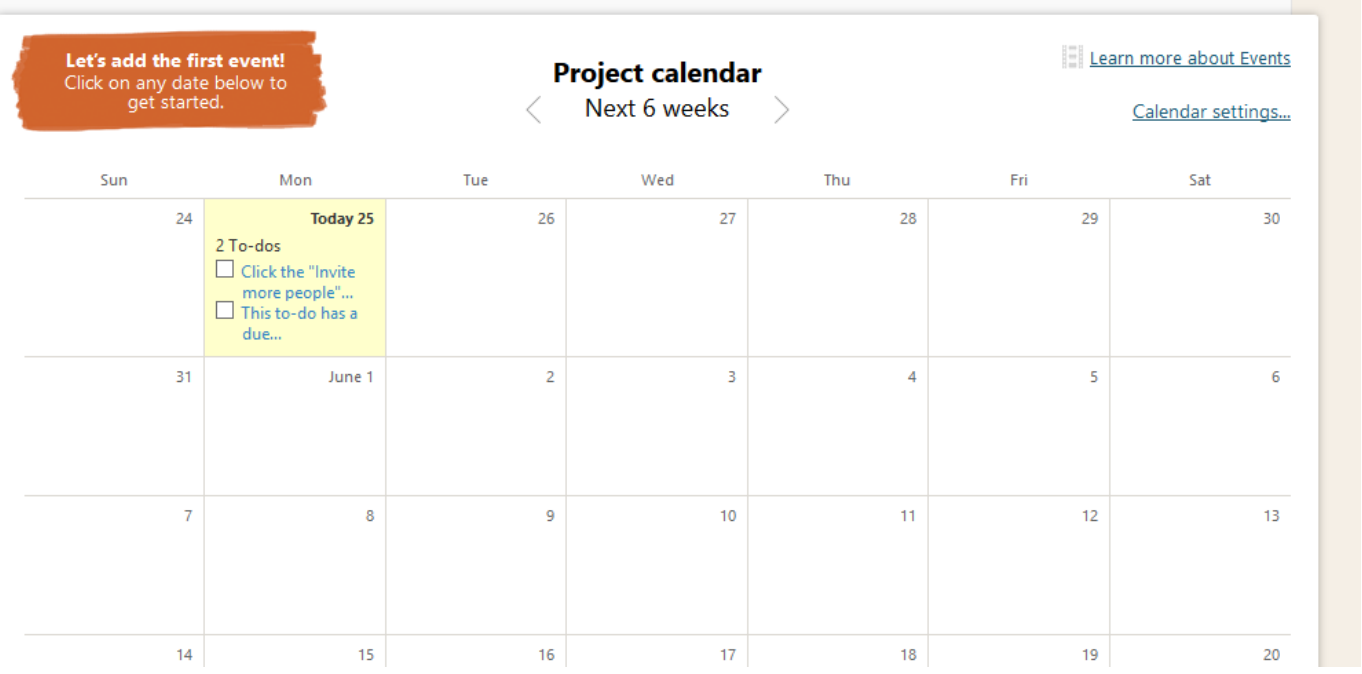

Figura 10: Exemplo de ambiente de tarefas no Basecamp.

Disponível em: <http://basecamp.com>.

Ao criar uma tarefa com prazo definido para a sua execução, ela também aparece no calendário do projeto.

\section{d) Arquivos}

$\mathrm{Na}$ área de arquivos, há um botão para transferir novos itens ao servidor e logo abaixo há uma lista dos arquivos já disponibilizados no ambiente, incluindo as seguintes informações relativas a cada arquivo: miniatura, nome (com extensão do arquivo), link 
para download e outro para a discussão relativa ao arquivo. Abaixo dessa lista, há um link para exibição dos arquivos antigos, que se abre em outra página, listando-os por data de inclusão.

Há também uma área de documentos de texto, que são notas visualizáveis e editáveis online, no próprio navegador, em um pequeno e simples editor de texto. A visualização destes documentos é em forma de lista, contendo o título e a informação de quando a lista foi modificada por último e por quem. As listas são salvas automaticamente enquanto a pessoa redige o texto.

\section{e) Linha do tempo}

Caso o usuário participe de muitos projetos, há a possibilidade de destacar os principais, que aparecerão na sua página inicial ao entrar no ambiente do Basecamp. Estes apresentam uma pequena descrição de cada projeto e exibe as imagens de perfil dos integrantes da equipe como visualizado na Figura 11 a seguir:

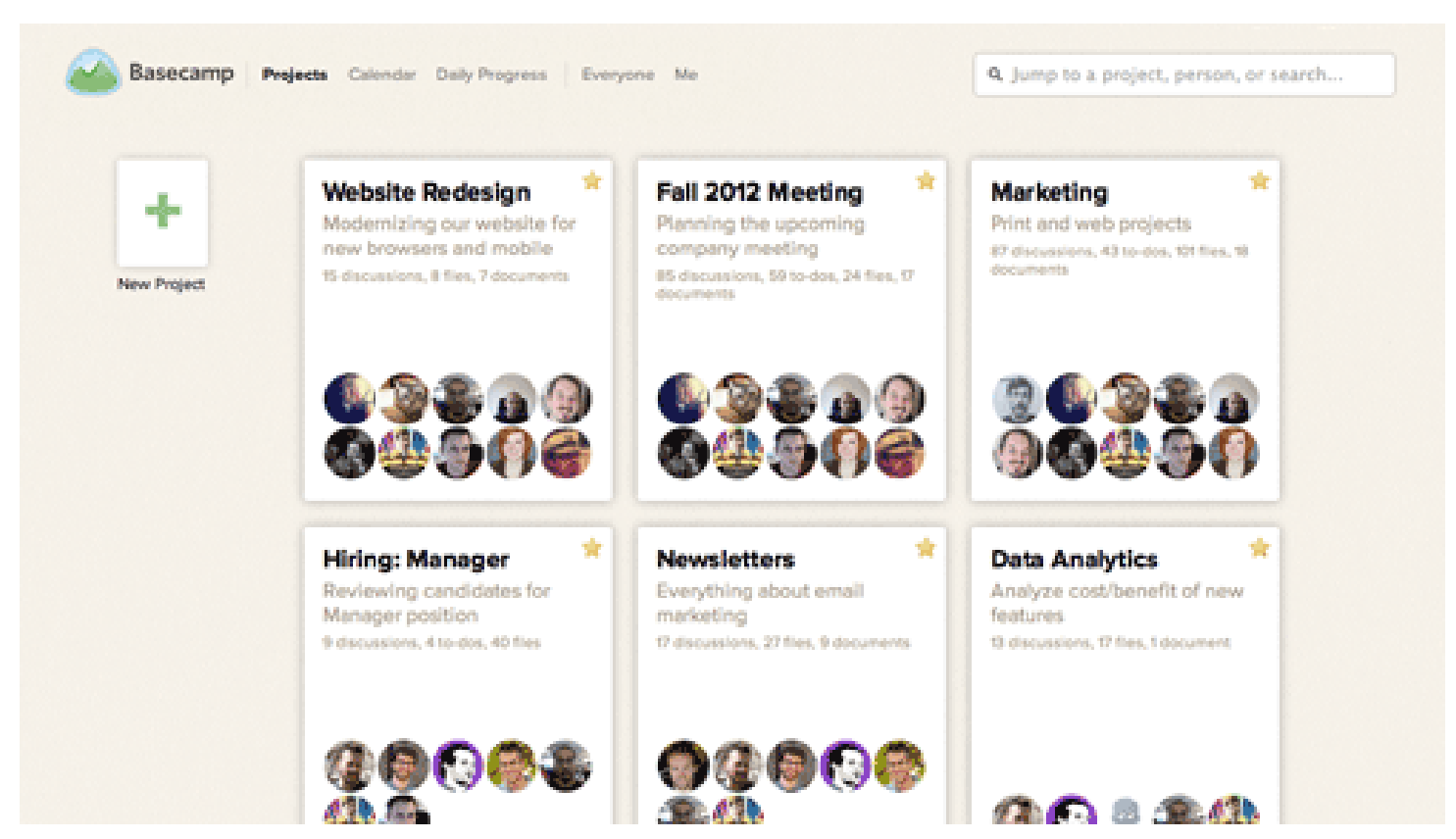

Figura 11: Exemplo de página inicial ao entrar no ambiente do Basecamp.

Disponível em: <http://basecamp.com>.

Abaixo dos que estão destacados, é exibida uma lista de projetos em ordem alfabética e um menu superior que permite ao usuário acessar as seguintes páginas: seu calendário, que permite ao usuário criar vários calendários diferentes para cada projeto, além de acompanhar os calendários de outros usuários, exibindo automaticamente prazos de projetos e tarefas para cada dia; seu progresso diário, que registra todas as 
suas atividades agrupadas por dia e horário de execução, como observado na Figura 12 a seguir; o link "Everyone", que permite ao usuário ver todas as pessoas e companhias (e departamentos internos destas) que participam de todos os projetos; e, por último, o link “Me”, uma página contendo suas atividades recentes e opções de configuração de informações pessoais e notificações por e-mail. Ainda há uma barra de busca por projetos, pessoas ou palavras em geral.

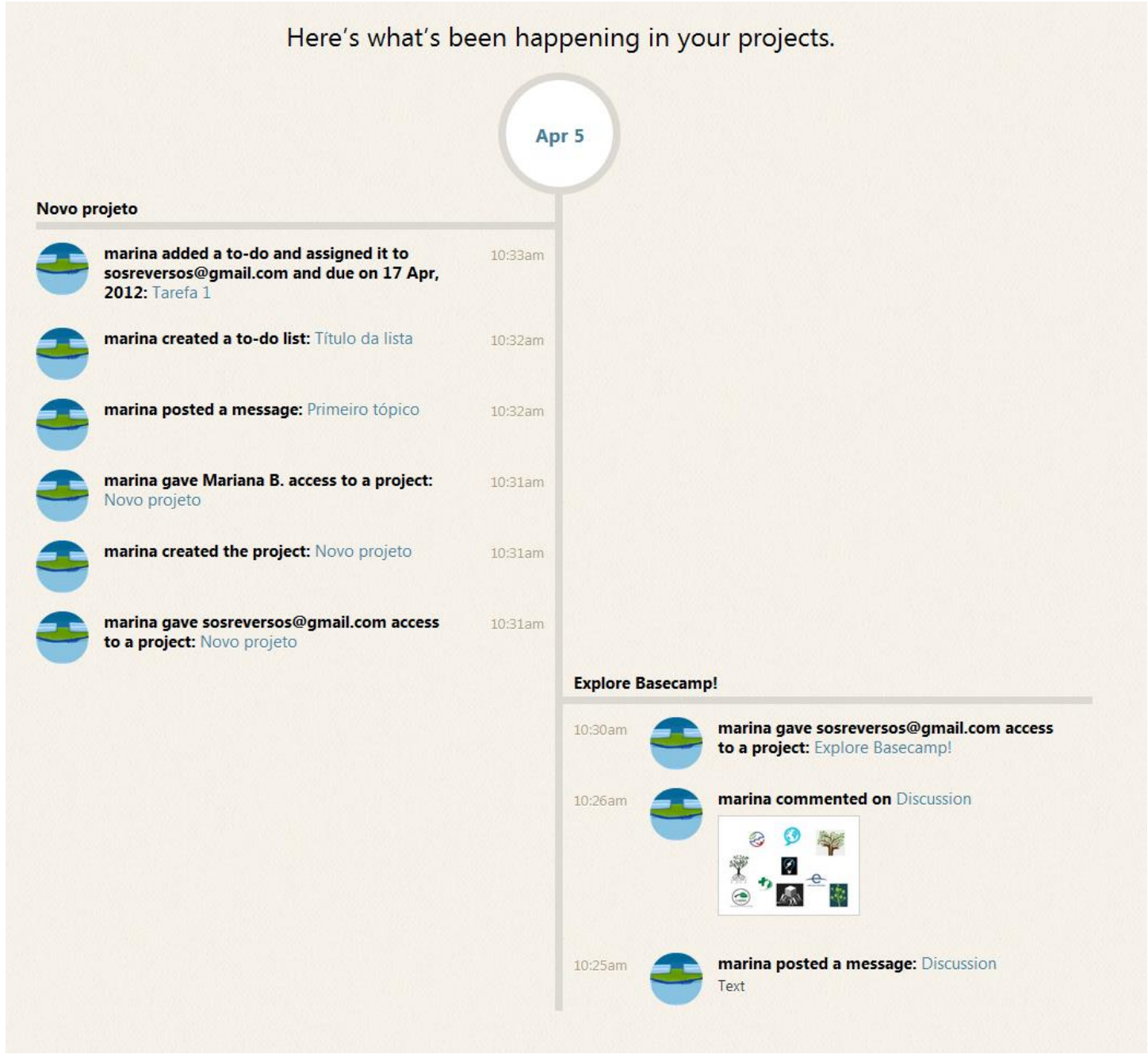

Figura 12: Exemplo do progresso diário de um usuário no Basecamp, agrupando as atividades por projeto. Disponível em: <http://basecamp.com>.

O Basecamp é uma excelente ferramenta de registro das informações do projeto, agrupando as informações relevantes. Na época da primeira análise do ambiente em 2012, a empresa ainda não havia desenvolvido aplicativos para dispositivos móveis. Estes já existiam no momento desta segunda análise, mas ainda não contam com tradução para outros idiomas além do inglês e seu acesso é somente online. Apesar disso, seu uso é intuitivo e, ao criar uma conta, há um projeto-modelo exemplificando 
tudo o que pode ser feito. O usuário pode inclusive modificar esse projeto a fim de testar suas funcionalidades.

Este ambiente promove a discussão entre os membros da equipe, já que em todas as áreas é permitido aos usuários comentar em imagens, textos e outros arquivos, além de escrever notas em conjunto, porém é uma ferramenta paga e normalmente utilizada por empresas de grande porte.

\section{Trello}

O Trello é uma ferramenta essencialmente visual, que cujo foco é a visualização rápida e completa de um projeto. Cada projeto é um "quadro" ao qual o usuário pode adicionar "cartões" em listas. Os quadros podem ser compartilhados com uma equipe, que têm autonomia para também editá-los.

O ambiente tem uma versão web construída com design responsivo, adaptando a quantidade de informação ao tamanho da tela do usuário, além de aplicativos para iOS, Android e Windows 8. Ele também conta com notificações para o usuário, avisando-o de quando são feitas modificações no projeto, que podem ser exibidas no próprio ambiente, enviadas por e-mail, para a área de trabalho pelo navegador ou no celular, sincronizando-as entre dispositivos. Há também uma ferramenta de busca por campo de texto, por filtros ou por etiquetas para recuperar informação.

Seguem abaixo os resultados da análise do Trello de acordo com o agrupamento da informação:

\section{a) Fóruns}

Os fóruns podem ser criados dentro de cartões, por meio de comentários individuais. Para responder um comentário, é necessário marcar o nome de usuário da pessoa a quem se deseja dirigir em um novo comentário. Eles não são exibidos de forma aninhada, como em um fórum, mas sim como mensagens individuais, como exibido na Figura 13. 


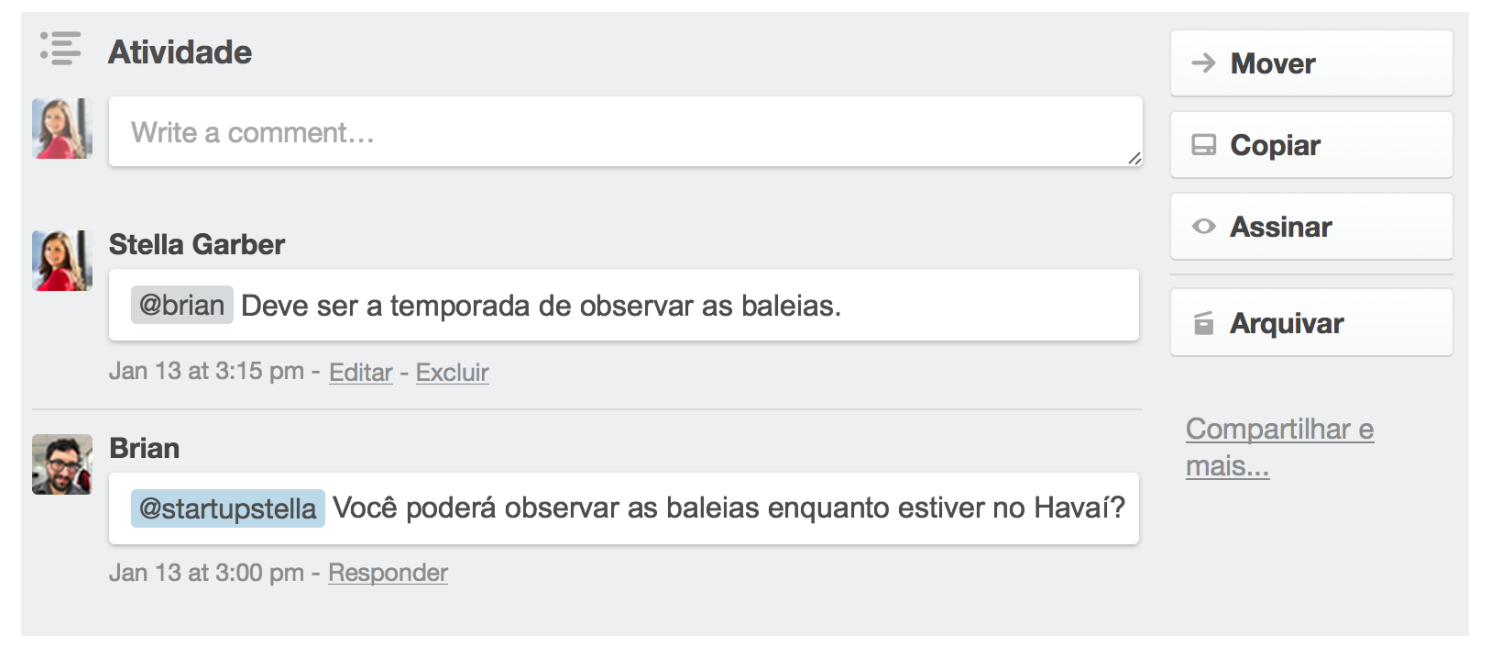

Figura 13: Exemplo de discussão em um cartão do Trello.

Disponível em: < https://trello.com/guide/collaborate.html>

Para realizar um comentário, há uma caixa de texto na qual o usuário pode escrever. Abaixo desta caixa há links para anexar arquivos, mencionar membros já adicionados ao quadro, adicionar emojis e vincular um cartão ao comentário.

\section{b) Tarefas}

Como explicado anteriormente, as tarefas do projeto são exibidas em um quadro, no qual podem ser agrupadas tarefas. Dentro de cada grupo há tarefas, dispostas em cartões. Neles, há a possibilidade de se dar um nome à tarefa, adicionar uma descrição e uma imagem, vincular os membros da equipe responsáveis por ela, e também classificála com uma etiqueta de cor personalizável, como observado na Figura 14. 


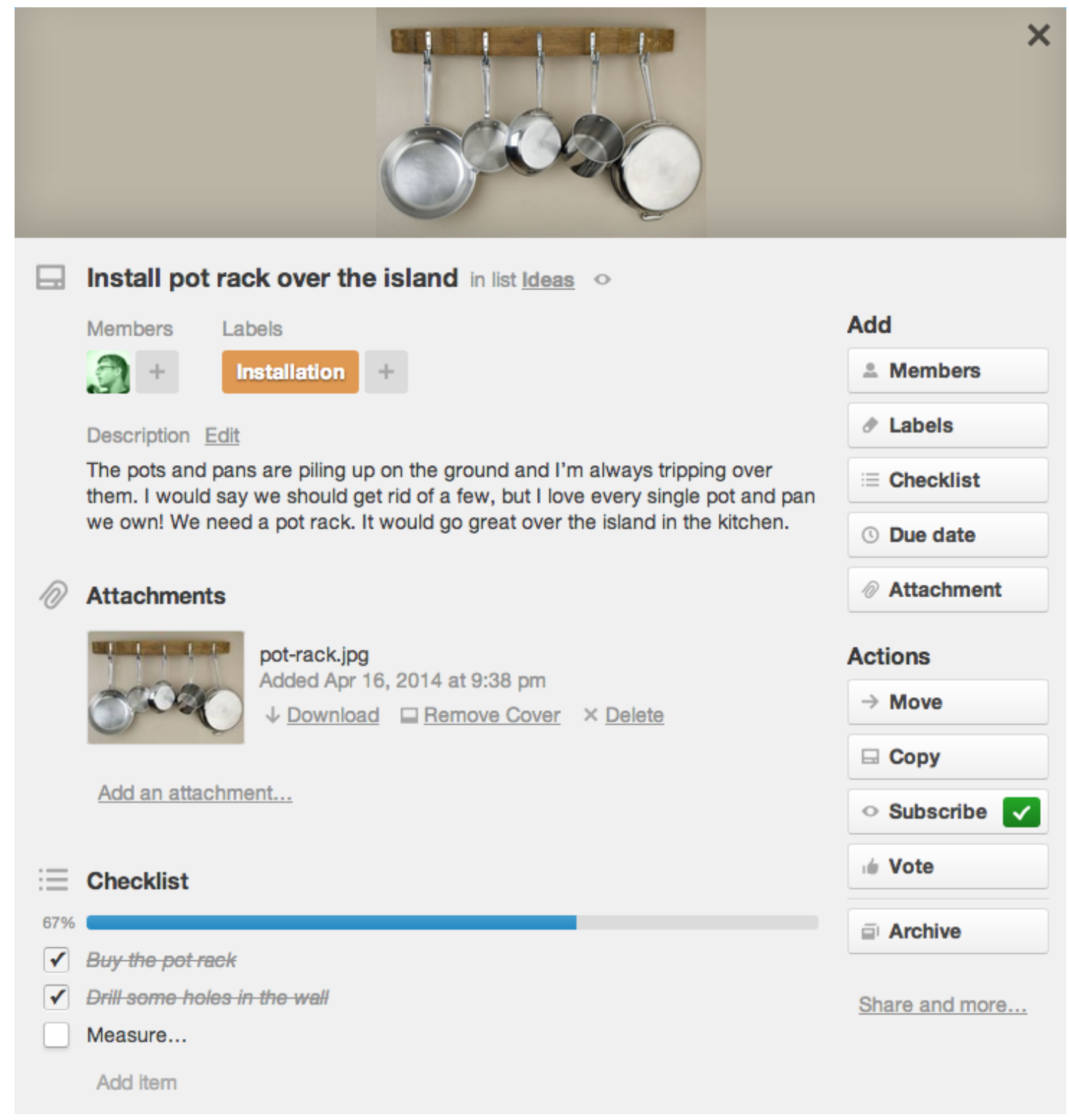

Figura 14: Exemplo de cartão do Trello.

Disponível em: <https://trello.com/home>

Além disso, podem ser adicionados arquivos em anexo, como imagens ou outros documentos; podem ser incluídas listas de tarefas mais específicas para se concluir a tarefa descrita no cartão; pode-se especificar uma data-limite para a finalização da tarefa; e pode-se incluir a possibilidade de os membros da equipe avaliarem a carta, ou tarefa, de maneira positiva ou negativa.

\section{c) Cronograma}

Existe a possibilidade de se vincular um calendário visual ao quadro, ou projeto, exibindo as atividades diárias por mês ou por semana. Essas datas também podem ser 
exportadas por meio de um feed para iCal, aceito por diversos aplicativos de calendário, como o Google Calendar.

\section{d) Arquivos}

Como mencionado anteriormente, cada carta tem a possibilidade de abrigar comentários dos membros do projeto, que podem anexar arquivos a partir do seu computador, ou de locais onde os tenha armazenados em nuvem, como Google Drive, Dropbox, Box ou OneDrive. Porém, não há um local específico no qual todos os arquivos possam ser encontrados, pois estes se vinculam apenas às cartas de origem.

\section{e) Linha do tempo}

O projeto é exibido como um quadro. O modelo disponível ao usuário mostra várias listas em um quadro, que representam diferentes etapas do projeto: ideias gerais, lista de tarefas a serem realizadas, atividades em andamento e tarefas realizadas. Este modelo de projeto, ilustrado na Figura 15 abaixo, se baseia no Kanban, que tem como princípio a visualização de todas as etapas do projeto, tanto as já executadas, como as futuras e as em execução para compreendê-lo, mas cada equipe tem liberdade para organizar seu quadro da maneira que melhor conseguir visualizar e compreender seu projeto.

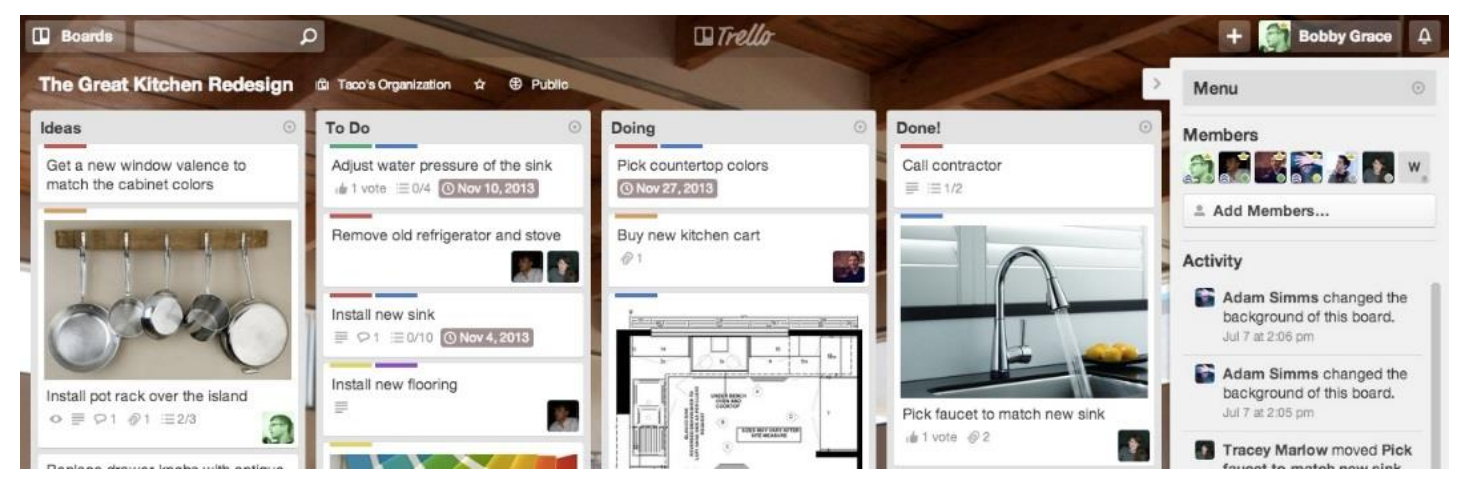

Figura 15: Exemplo de quadro do Trello.

Disponível em: <https://trello.com/home>

O Trello mostra-se como uma ferramenta para visualizar projetos não muito complexos, pois o tamanho da tela limita a percepção do projeto por inteiro, sendo necessário ocultar algumas seções e cartões para vislumbrar as próximas ações de um projeto, caso ele seja muito grande.

Apesar disso, ele viabiliza a organização do projeto de forma colaborativa e a discussão de tarefas entre a equipe. Os projetos também podem ser acessados de 
qualquer lugar, mas não a qualquer tempo, pois é necessária conexão à internet para visualizar e modificar cartões.

Portanto, nenhum dos ambientes responde a todos aos requisitos levantados. Ainda não há, em meio digital, um local acessível, dentro do mesmo ambiente, que permita aos usuários, simultânea e abertamente, ter conhecimento das seguintes atividades: listar interesses; encontrar pessoas com interesses semelhantes; indexar documentos; conversar, debater, planejar e registrar atividades; nem acompanhar abertamente o desenvolvimento do projeto para que mesmo as pessoas que não estejam envolvidas diretamente na execução do projeto possam se beneficiar da observação do processo para compreendê-lo e replicá-lo ao seu contexto ou utilizá-lo como base para aprimorá-lo.

\subsection{Necessidade da construção de um ambiente colaborativo para auxiliar a comunicação e o registro de projetos colaborativos}

Após a realização da análise apresentada posteriormente, foi avaliado que os espaços estudados não atendem a todas as necessidades de um projeto colaborativo. As TICs podem ser melhor utilizadas, aproveitando suas múltiplas possibilidades com vistas a aproximar todos os envolvidos para pensar em no desenvolvimento de soluções de problemas, compartilhar informações e gerar conhecimento de forma colaborativa.

A partir deste cenário, foi pensada a concepção de um aplicativo para auxiliar o gerenciamento colaborativo de projetos, especialmente em disciplinas que aplicam o PBL e têm um grande número de alunos, possibilitando o uso de dispositivos móveis sem que o volume de trocas entre estudantes atrapalhe no resgate de informações relevantes. 


\section{$3^{0}$ Capítulo: Proposta de ambiente de aprendizagem por projetos baseada em metodologias colaborativas}

Após a compreensão, no capítulo anterior, dos contextos e das necessidades de projetos colaborativos por meio da entrevista realizada e dos questionários aplicados, somados à revisão bibliográfica do primeiro capítulo e às experiências empíricas da equipe de pesquisa e desenvolvimento na participação de projetos, foi possível levantar requisitos para ambientes colaborativos e analisar as soluções existentes.

Porém, após a realização desta análise, observou-se que os espaços escolhidos não atendem a todas as necessidades de um projeto colaborativo, provando a necessidade do planejamento e do desenvolvimento de um aplicativo para auxiliar o gerenciamento colaborativo de projetos, que será apresentado neste capítulo. Esta etapa compreende a arquitetura da informação, os wireframes e as imagens da solução projetada, considerando como esta busca atender aos requisitos levantados. Em sequência, é apresentada a dinâmica de validação dos termos utilizados no aplicativo desenvolvido, com o objetivo de verificar a acessibilidade e a compreensão dos termos por outros contextos de desenvolvimento de projetos colaborativos.

\subsection{Construção de um aplicativo para o gerenciamento de projetos colaborativos}

Ao se pensar o nome para o aplicativo, foi escolhida a palavra Tiê, do idioma Tupi. Tiê é o nome de uma espécie brasileira de pássaro, cuja figura simboliza liberdade e comunicação. Além disso, a palavra "tie", em inglês, envolve os conceitos de vínculo e de conexão, além de outros significados vinculados à administração e à engenharia. Pela combinação de todos estes sentidos, Tiê não simboliza apenas um vínculo, mas também representa a união dos processos de comunicação em um projeto colaborativo (Garrossini \& Maranhão, 2014).

Essa conceituação baseou o desenvolvimento da identidade visual, resultando em um ícone que mescla o pássaro da espécie

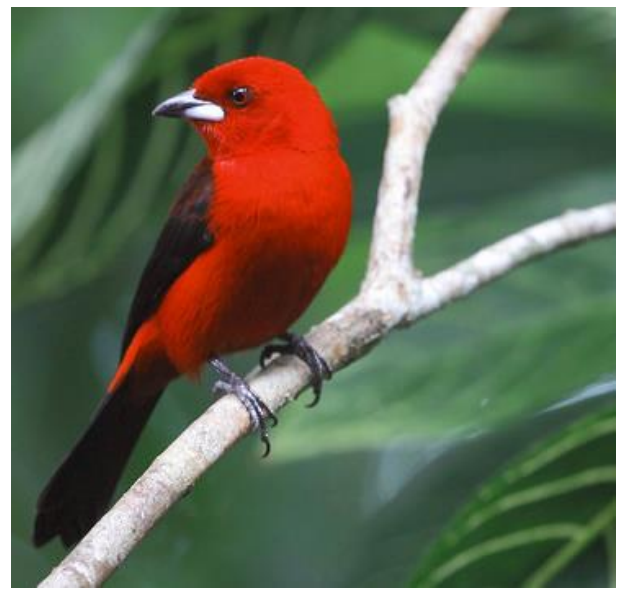

Figura 16: Tiê-sangue (Ramphocelus bresilius) por Hector Bottai (CC BY-SA 2.0) 
Tiê-sangue (Ramphocelus bresilius) a um balão de fala, tendo como paleta cromática as cores desta espécie, ou seja, preto e vermelho. As cores auxiliares foram escolhidas a partir do padrão feito pelo Google e disponibilizado em suas diretrizes para a construção de aplicativos (GOOGLE, 2015), de modo a familiarizar os usuários, utilizando um padrão de cores ao qual ele já está acostumado em outras experiências em seu dispositivo móvel.

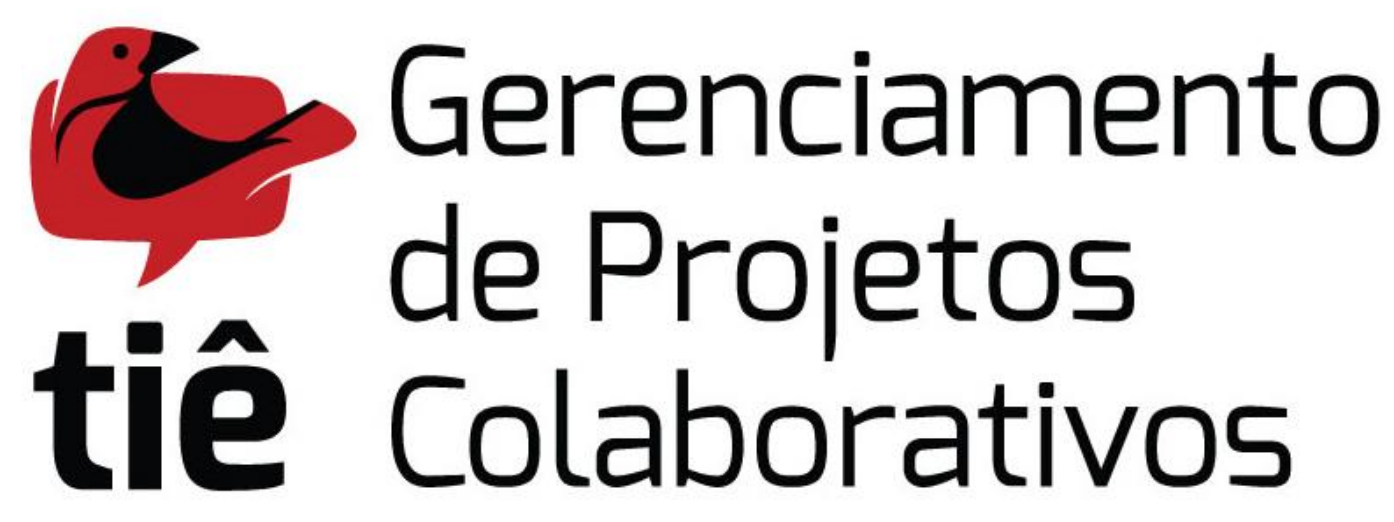

Figura 17: Logotipo do aplicativo Tiê

Porém, antes mesmo de nomear o ambiente, a equipe havia iniciado o projeto da estrutura do aplicativo, buscando atender ao estudo do agrupamento de informações semelhantes com o objetivo de simplificar a posterior recuperação destes dados no momento que o usuário desejar, pensando na sequência de ações possíveis a serem realizadas no ambiente. Os desdobramentos das possibilidades de interação com as ferramentas presentes no ambiente ampliaram ainda mais a estrutura do Tiê, pois observou-se que, para atender aos objetivos de forma holística, era necessário que as funcionalidades projetadas fossem integradas entre si e aos recursos dos dispositivos móveis, integrando pessoas, áreas e projetos, pensando não somente no macro, mas importando-se também com suas ramificações, planejando como seria a interação dos usuários com as diferentes etapas de projeto e com as ações do grupo em sua totalidade, além dos diferentes papéis exercidos por eles, como coordenação e liderança, resultando na estrutura representada na Figura 18. 


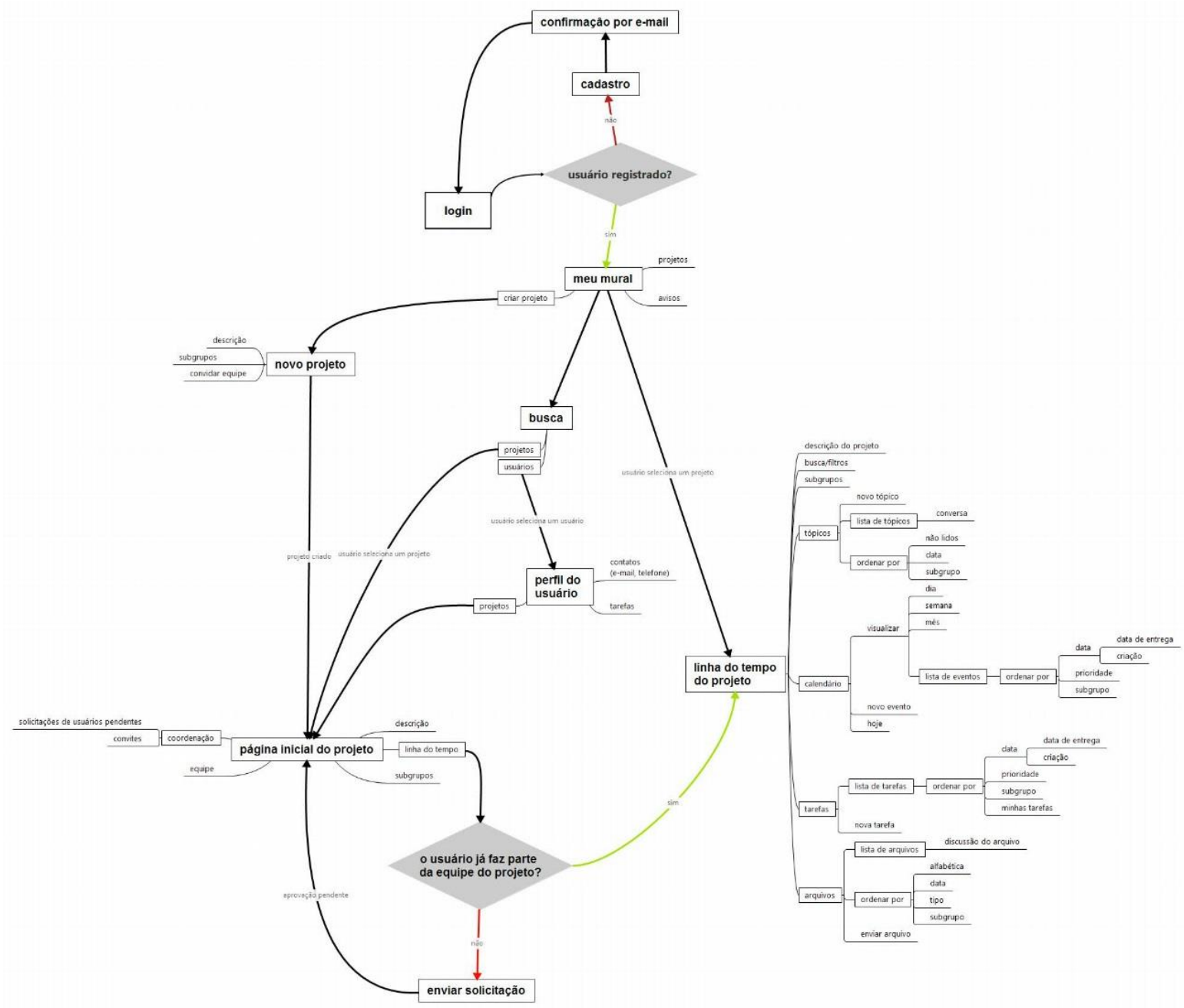

Figura 18: Arquitetura do aplicativo Tiê

Descreveu-se, a partir da concepção da estrutura do aplicativo, cada tela que representa as funcionalidades essenciais para o usuário. Estas descrições seguiram-se de wireframes para representar a distribuição visual das informações para o usuário. Segundo Garrett (2011), estes representam graficamente os elementos essenciais que permitem exibir o conteúdo da melhor maneira para o usuário, permitindo mapear o ambiente por meio da visualização das funções necessárias, verificando se foram incluídas, além de permitir a representação do uso pelos usuários, sem se ater a detalhes estéticos como cores e formas. A preocupação do desenho de wireframes é com a disposição dos elementos na tela, tamanhos e formas de ícones e acesso às informações de forma rápida e que faça sentido ao usuário.

A seguir estão descritas as telas que representam as funcionalidades essenciais do ambiente, de modo a permitir a compreensão da tradução da estrutura do aplicativo 
como percebida visualmente pelo usuário para que, em seguida, possa ser apresentada a análise de acordo com os requisitos gerados neste trabalho.

\section{Tela Login}

Esta tela apresenta o logotipo do aplicativo na parte superior, seguido por dois campos de texto: um para a inserção do e-mail e outro para a senha, caso o usuário já esteja registrado.

Abaixo, há a opção de manter o usuário conectado ao fazer login, impedindo que essa tela apareça todas as vezes que ele entrar. Ou seja, caso selecione esta opção, da próxima vez que a pessoa abra o aplicativo, ela irá direto para a listagem dos seus projetos.

Caso o usuário não se lembre das informações necessárias para entrar no ambiente, há um link para recuperar a senha.

- O campo "E-mail" serve para que o usuário digite o endereço eletrônico utilizado em seu cadastro no aplicativo. Não há

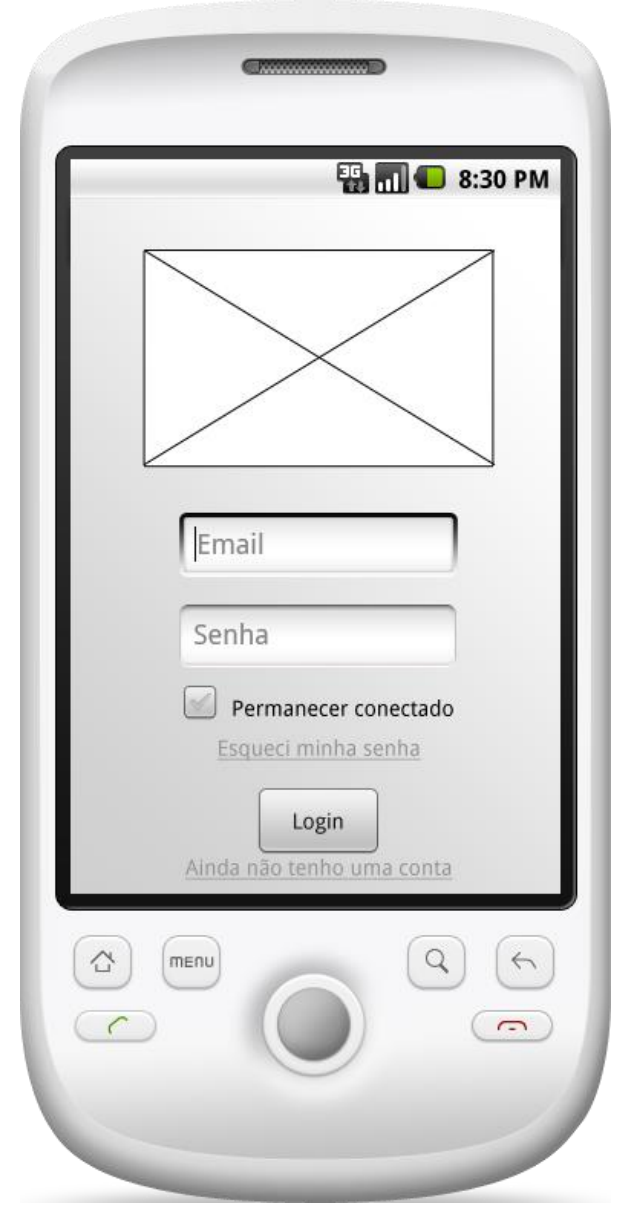

Figura 19: Representação da tela de login limite de caracteres, mas ele deve obedecer à estrutura de um e-mail típico, ou seja, ele deve conter um símbolo@e ao menos um ponto.

- O campo "Senha" é solicitado para confirmar a autenticidade do usuário e preservar sua privacidade. Cada usuário cadastra a senha que preferir quando efetua o registro no aplicativo, e poderá alterá-la a qualquer momento. Ele deve conter no mínimo quatro caracteres. Não há limitações quanto aos tipos de caracteres que podem ser usados na senha, nem tamanho máximo.

- O link “Login” deverá ser clicado pelo usuário após inserir as informações de e-mail e senha. É um link que pode efetuar duas ações possíveis: uma 
para usuários registrados no sistema e outra para novos usuários. Se as informações inseridas pelo usuário forem reconhecidas pelo aplicativo, ele será enviado para a Tela Inicial. Se o e-mail for reconhecido, mas a senha estiver correta, será aberta uma notificação pedindo para o usuário verificar a senha. Caso o e-mail não esteja cadastrado no sistema, o usuário será redirecionado para a tela de Cadastro.

- O campo "Lembrar Usuário" é de seleção. Assim, o usuário poderá ou não marcá-lo para evitar que volte a essa tela de Login nas próximas vezes que abrir o aplicativo. Se a opção estiver marcada, no próximo login o usuário será enviado diretamente para a listagem de projetos. Caso contrário, a tela de inserção de e-mail e senha continuará aparecendo e solicitando a confirmação das informações. É um botão de caixa de seleção, desmarcado por padrão e que pode ser marcado pelo usuário.

- O link "Esqueci Minha Senha" leva o usuário a uma tela para recuperar as informações cadastradas caso tenha esquecido seu e-mail ou senha. $\mathrm{O}$ aplicativo solicitará o número do telefone celular. Ao informar o número, será identificado no perfil o e-mail cadastrado para onde será enviada a senha. 


\section{Tela Cadastro}

Esta tela é exibida para os usuários cujo e-mail não tenha sido reconhecido pelo sistema ao se cadastrem no aplicativo. Ela apresenta cinco campos de texto e um link de envio.

É permitido o cadastro de apenas uma conta por e-mail a fim de evitar problemas de segurança. Para que o usuário necessite repetir as informações inseridas na Tela de Login, o sistema grava automaticamente os dados já obtidos nos campos de E-mail e Senha naquela tela, caso o usuário já os tenha digitado. Aqui, ele precisará apenas confirmar as informações para efetuar o cadastro e verificar se não houve equívocos no preenchimento.

- Campo "Confirmar E-mail": tem a finalidade de, assim como no campo

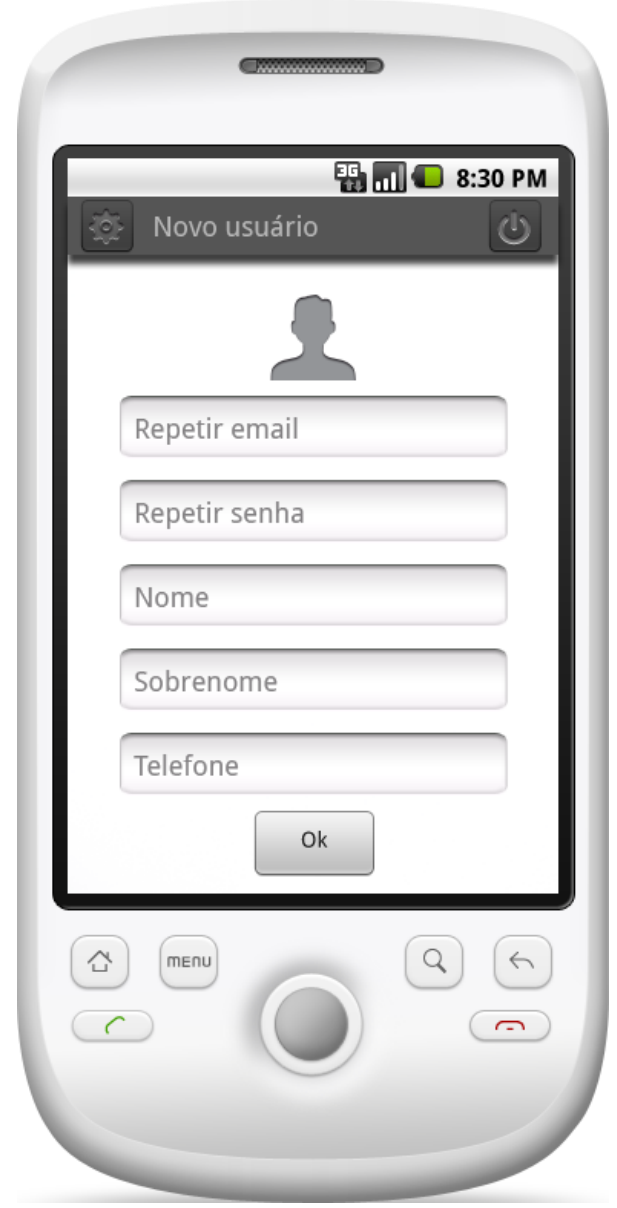

Figura 20: Representação da tela de cadastro E-mail da Tela Inicial, permitir a inserção do endereço eletrônico do usuário, que será utilizado para o login no aplicativo. Como o endereço digitado na tela anterior é registrado pelo aplicativo, este campo tem a finalidade de confirmar se o e-mail digitado anteriormente está correto. Se estiver, aparecerá uma informação confirmando que as informações coincidem, caso contrário, o usuário corrigir o e-mail inserido.

- Campo "Confirmar E-mail": obedece à mesma estrutura do campo E-mail.

- Campo "Confirmar Senha": tem função semelhante à de "Confirmar Email". O aplicativo registra a senha digitada na tela Login e o usuário deve confirmá-la aqui. Se a senha digitada coincidir, aparecerá uma informação confirmando que os caracteres inseridos são iguais, caso contrário, o usuário precisará digitá-los novamente.

- Campo "Senha": obedece à mesma estrutura do campo "Senha" na tela "Login". 
- Campo "Nome Completo": Esta é uma das informações básicas do perfil de todos os usuários cadastrados no aplicativo, que auxilia a localização de outras pessoas no banco de dados e facilita inseri-las em projetos. Este campo deve conter ao menos duas palavras, aceita acentos gráficos e reconhece a diferenciação de maiúsculas e minúsculas.

- Campo "Telefone”: também é um dos campos básicos do perfil de todos os usuários. Esta informação ficará visível no perfil do usuário apenas para aqueles que estiverem no (s) mesmo (s) projeto (s). Ele deverá seguir a estrutura DDD + número. O ideal é que exista algum tipo de separação entre o DDD e o número em si. É composto por dez caracteres, apenas numerais.

Ao final do processo de cadastro será enviado um e-mail com mensagens de boasvindas ao sistema. 


\section{Tela Inicial (Meu Mural)}

Esta é a primeira tela à qual o usuário é direcionado após o login. Ela é o centro de notificações e o local onde consta a listagem de projetos do usuário. Ela também permite acesso às telas de pesquisa e de configurações do aplicativo.

- O quadro "Avisos" traz as principais notificações dos projetos em que o usuário está cadastrado. Os avisos se alternam na tela e podem ser notificações de novos usuários ou eventos em um projeto.

- O link "Projetos" leva o usuário para uma lista com os projetos que participa. Ao selecionar um projeto, ele é redirecionado para a sua respectiva linha do tempo.

- O link "Criar Projeto" leva o usuário

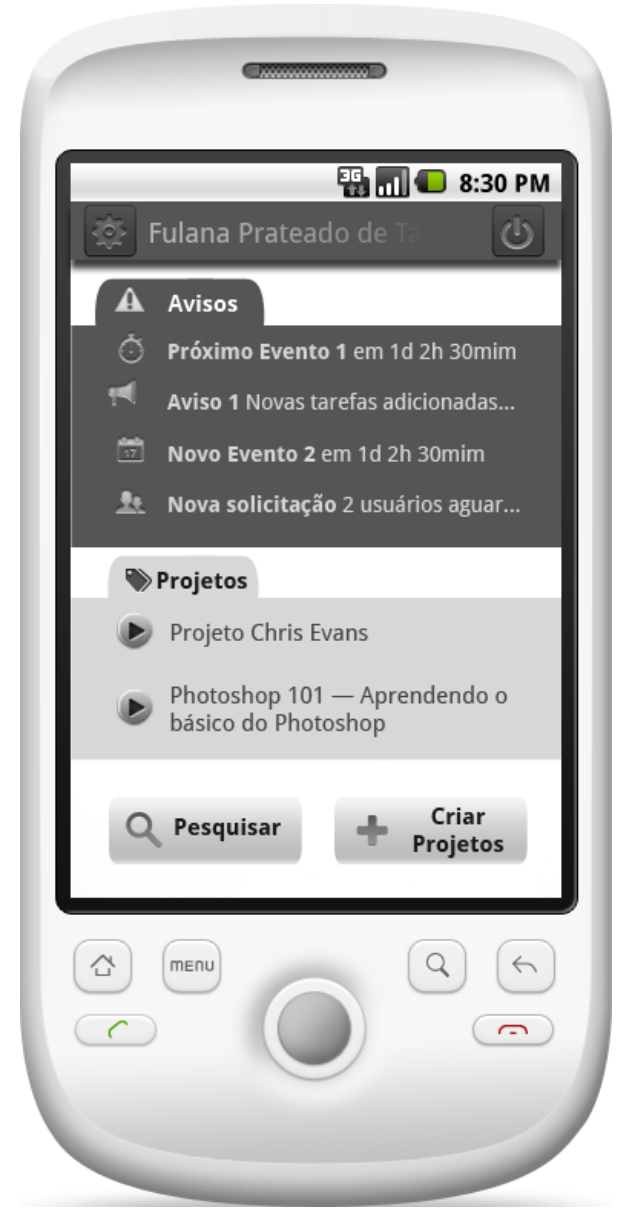

Figura 21: Representação do mural de projetos do usuário para a tela de mesmo nome, que permite a criação e configuração de um novo projeto. Todos os usuários podem criar novos projetos.

- O link "Pesquisa" (Buscar projeto ou Buscar usuário) leva o usuário para uma tela de busca e permite a localização de projetos e usuários cadastrados no aplicativo.

- O link "Configurações” leva o usuário para a tela de mesmo nome, na qual o usuário pode alterar as preferências do aplicativo.

- O link “Logout” está presente em praticamente todas as telas do aplicativo, permitindo que o usuário saia da sua conta, retornando para a tela "Login". 


\section{Tela Pesquisar}

A tela de pesquisa permite ao usuário buscar por projetos já existentes no sistema, ou por outros usuários. Ela consiste em um simples campo onde o usuário deve escrever o termo que deseja pesquisar.

- Campo "Pesquisa": sem limite de caracteres. É o espaço no qual o usuário digita os termos a serem procurados, que são posteriormente classificados entre usuários e projetos nos resultados de busca.

Caso o usuário selecione um projeto, ele será levado à tela "Descrição do Projeto". De maneira semelhante, os resultados de usuários são todos links para a tela "Usuário" de cada pessoa listada.

- O link “Configurações" leva à tela de configurações gerais do aplicativo. Não é necessário haver configurações específicas para a busca.

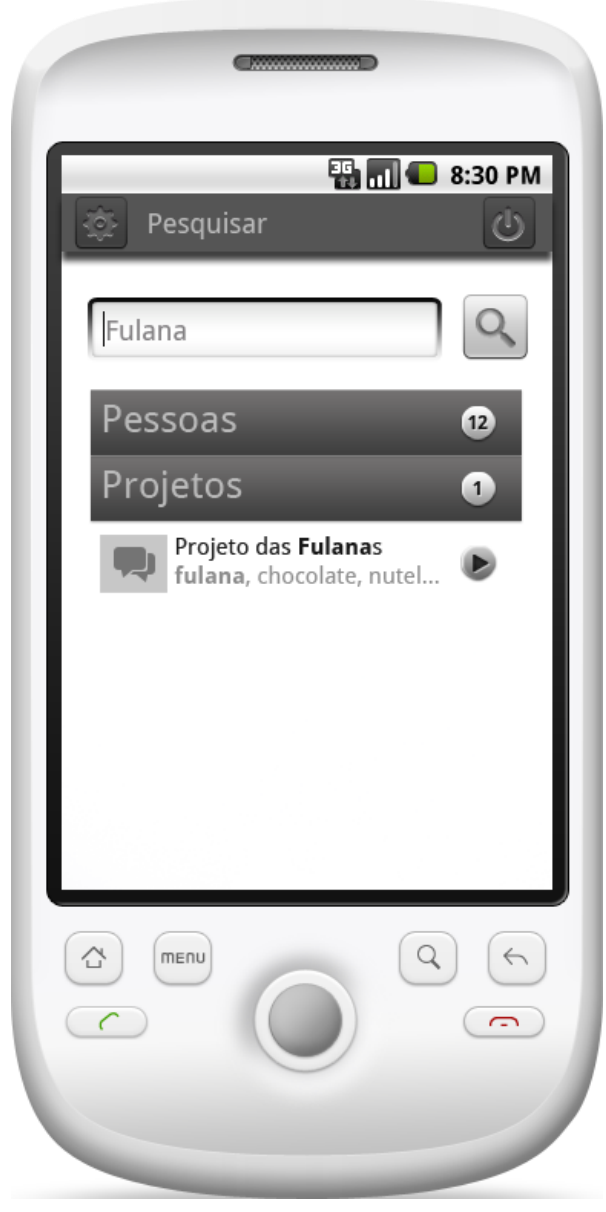

Figura 22: Representação da tela de busca 


\section{Tela Criar Projeto}

Esta tela permite que ao usuário criar um novo projeto e definir suas principais informações.

- O campo "Nome do Projeto" serve para que o usuário insira um nome curto e objetivo identificando a ideia principal do projeto. Máximo de 50 caracteres, de a-z e 0-9, permitindo acentos.

- O campo "Descrição" serve para que o usuário insira os objetivos e um resumo do projeto.

- O link "Subgrupos" permite que o usuário crie os grupos de trabalho do projeto. Na tela de Subgrupos, há os campos de "Nome do Subgrupo" e "Descrição".

- O link "Convite" permite que o usuário procure e adicione outros

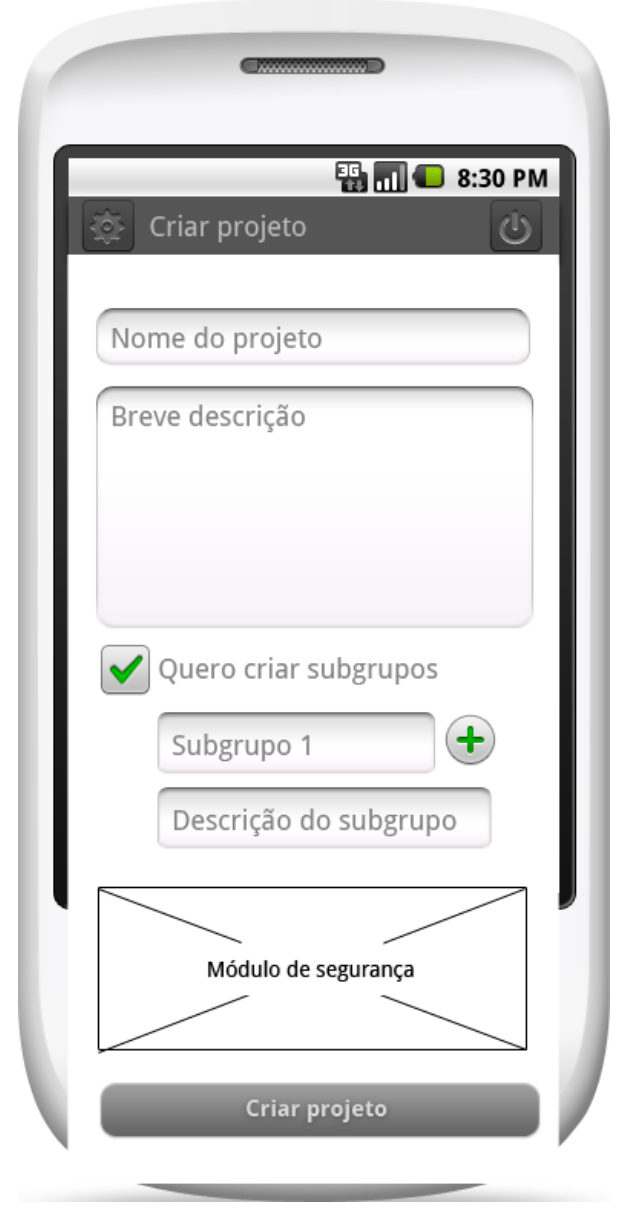

Figura 23: Representação da tela de criação de projeto usuários do aplicativo ao projeto. Se o projeto possui subgrupos, o usuário pode adicionar os convidados diretamente aos grupos de trabalho desejados. Caso a pessoa convidada não possua conta no ambiente, ela recebe um e-mail convidando-a a instalar o aplicativo.

Há também a possibilidade de se adicionar um módulo de segurança para evitar a criação de projetos-fantasma. 


\section{Tela Usuário}

Esta tela exibe as informações individuais das pessoas cadastradas no sistema, como um perfil. $\mathrm{O}$ ato de selecionar resultados de pesquisa relativas a um usuário ou de clicar em nomes de usuários em qualquer outro lugar do ambiente levam à esta tela.

Nela, é possível visualizar o nome completo, a foto, o e-mail e os projetos ativos de qualquer pessoa que esteja cadastrada. Caso a pessoa esteja no mesmo projeto que o usuário que a procurou, também estarão disponíveis informações extras, como número de telefone.

- O link "Projetos" leva à lista de projetos ativos de um usuário. Cada nome é um link para a página principal dos mesmos.

- O link “Configurações" leva a uma seção que permite ao usuário editar

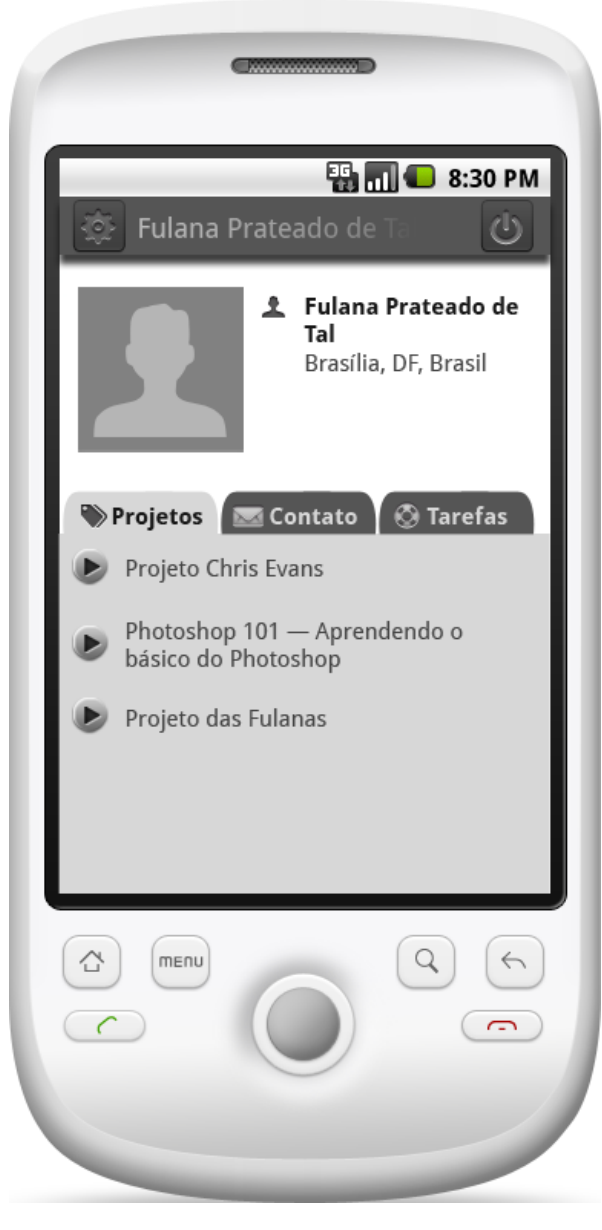

Figura 24: Representação da tela de perfil do usuário seu próprio perfil, inserindo informações não solicitadas na tela inicial de cadastro. Ele também pode alterar os dados existentes.

- Na aba "Contato" são exibidos os dados pessoais do usuário, como telefone, e-mail, perfis em redes sociais ou contatos em aplicativos de mensagem instantânea. Esta seção somente pode ser vista por alguém que tenha o usuário adicionado.

- Aba "Tarefas": lista as tarefas para as quais a pessoa foi designada. 


\section{Tela Descrição do Projeto}

Esta tela exibe para o usuário as informações sobre o projeto selecionado em seu mural, ou de um resultado de pesquisa. Ela também pode ser acessada a partir de projetos listados de outras pessoas na tela Usuário.

A "Descrição do projeto" apresenta um resumo dos objetivos do projeto, a lista de participantes (evidenciando os coordenadores e demais responsáveis), e uma aba com os subgrupos do projeto, caso existam.

Caso o usuário selecione o nome de outro na lista de participantes, ele é levado à tela Usuário.

- O link “Solicitação" estará visível caso o usuário ainda não seja participante daquele projeto.

Selecionar esse link abrirá a lista de subgrupos do projeto, caso existam,

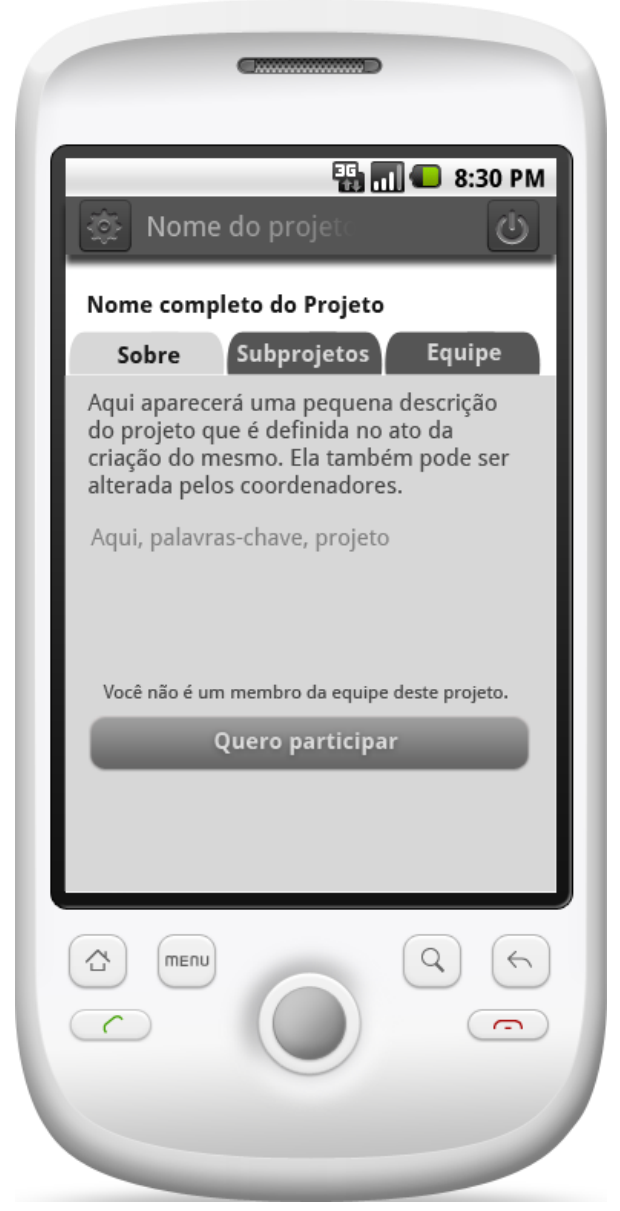

Figura 25: Representação da tela de descrição de projeto para que se escolha qual o subgrupo que o usuário deseja fazer parte. Feita esta seleção, ou caso não haja subgrupos, o sistema enviará uma solicitação de participação do usuário para o coordenador do projeto. Um pop-up "Solicitação Enviada" será exibido confirmando o envio, e o link Solicitação deixará de funcionar. A partir de então, o projeto aparecerá na Tela Inicial do usuário com o status de "aguardando aceitação" até que o coordenador o adicione aos membros.

- A aba "Subgrupo" é acessível apenas pela tela "Descrição do Projeto". Um subgrupo consiste em um conjunto de pessoas que compõem distintas equipes do projeto, com funções e tarefas de áreas diferentes, mas que contribuem para o resultado final do projeto. Essa tela lista todos os subgrupos desse projeto.

- A aba "Equipe" lista os participantes do projeto, destacando também o coordenador do mesmo. 


\section{Tela Linha do Tempo do Projeto}

Nesta tela constam os links "Grupos", "Fóruns", “Descrição”, "Busca/Filtros”, “Calendário”, "Lista de Tarefas", "Arquivos", "Configuração" e "Logout"; além de ser exibida a própria linha do tempo.

Ela consiste em uma estrutura com links para quaisquer ações que possam ser realizadas dentro do grupo: isto inclui adição de arquivos, criação de fóruns de discussão, inclusão de novos membros ao projeto, eventos agendados, comentários feitos por membros, avisos, tarefas realizadas ou especificadas e saída de membros.

Todos estes envios são acessíveis por qualquer membro do projeto e estão organizados de forma cronológica como ramificações de uma reta que exibe data e hora de cada adição e que pode ser navegada para mostrar adições realizadas a qualquer momento. Para tornar a navegação da linha do tempo mais prática, há marcadores de subgrupos que facilitam a visualização de fóruns de interesse dos membros, além de ferramentas, na forma de Busca e Filtros, que restringem a aparição dos itens da linha do tempo de acordo com as necessidades do usuário.

- O nome do projeto funciona como link e direciona o usuário para a página de descrição do projeto.

- "Busca/Filtros" são ferramentas que permitem ao usuário customizar como será a visualização dos itens na linha do tempo do projeto, exibindo apenas os itens que satisfaçam aos critérios especificados. Para a "Busca", serão mostradas apenas as entradas da linha do tempo que contêm determinado termo fornecido pelo usuário. Os "Filtros” são opções pré-estabelecidas que operam de forma semelhante à "Busca", porém utilizando critérios prontos que limitam as exibições da linha do tempo a um ou mais determinados tipos (dependendo da quantidade de filtros selecionados). 
Dentre estes filtros estão inclusas, por exemplo, limitações a entradas que fazem referência a subgrupos específicos, fóruns, arquivos adicionados ou eventos.

- O link de um Fórum exibe a "Página de Fórum Expandido" do fórum em questão.

- O link de um Evento exibe a "Página de Evento Expandido" do evento em questão.

- O link de uma Tarefa exibe a "Página da Tarefa Expandida" da tarefa em questão.

- O link de um Arquivo que foi adicionado exibe a "Página de Fórum Expandido" do arquivo em questão.

- O link de um Usuário que foi adicionado ao projeto exibe a "Página de Usuário" do usuário em questão.

- O "Menu flutuante" consiste em seis links para diferentes áreas: "Tela inicial", "Calendário", “Tarefas", "Fóruns”, “Arquivos” e “Gerenciar Projetos".

- O link "Tela inicial" redireciona o usuário para esta tela, onde é possível mudar de linha do tempo entre os projetos existentes.

- O link "Calendário" leva o usuário para a tela "Calendário" do projeto em questão.

- O link "Tarefas" leva o usuário para a tela "Tarefas" do projeto no qual ele se encontra.

- O link "Fóruns" leva o usuário para a tela "Fóruns" do projeto em que ele se encontra.

- O link "Arquivos" leva o usuário para a tela "Arquivos" do projeto em que ele se encontra.

- O link "Gerenciar Projetos" leva o usuário para a tela "Configuração" onde é possível administrar todos os projetos que ele gerencie. 


\section{Tela Fóruns}

Esta tela tem como objetivos básicos levar o usuário à criação de um novo fórum de discussão, visualizar fóruns anteriormente criados e expandi-los para que seja possível ler os comentários escritos por outros usuários referentes a cada um dos fóruns.

A página em questão possui os links "Fórum Expandido", "Criar fórum", “Organizar”, "Configurações” e "Logout".

- O link "Fórum Expandido" leva o usuário para a tela de mesmo nome, onde se localizam todas as informações, arquivos e comentários relacionados ao fórum selecionado.

- O link "Criar fórum” leva o usuário para a tela de mesmo nome, onde é possível criar um fórum de discussão

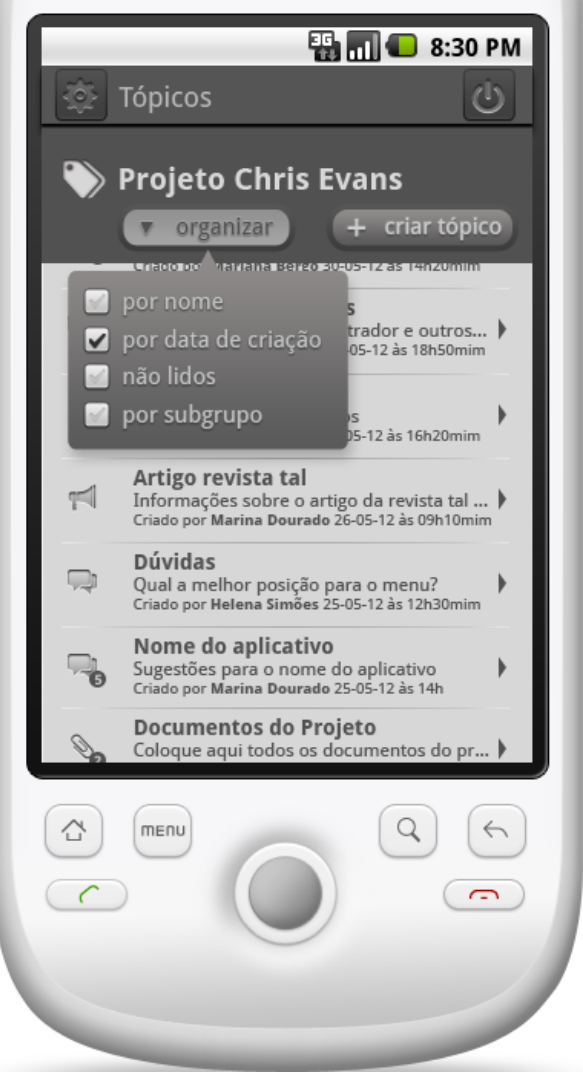

Figura 27: Representação da tela de fóruns do projeto contendo título, texto e imagem.

Também possível acrescentar novos arquivos a partir do armazenamento do próprio celular.

- O link “Organizar” abre um menu no qual é possível organizar os fóruns por ordem alfabética, ordem cronológica de criação, fóruns não lidos em ordem de criação e por subgrupo. 


\section{Tela Fórum Expandido}

Assim que o usuário clica em um dos fóruns da lista, o fórum se expande dando lugar às informações referentes a ele, tais como "Título", "tex to inserido" e "arquivo anexo".

- O link do "Arquivo anexo" abre um pop-up contendo opções de visualização do arquivo. Por exemplo, a visualização de uma foto na galeria do celular, outro aplicativo instalado no dispositivo do usuário.

- O campo "Inserir Comentário" permite ao usuário fazer observações de no máximo 140 caracteres sobre o fórum em questão. Assim que o usuário clica neste campo, o teclado abre automaticamente.

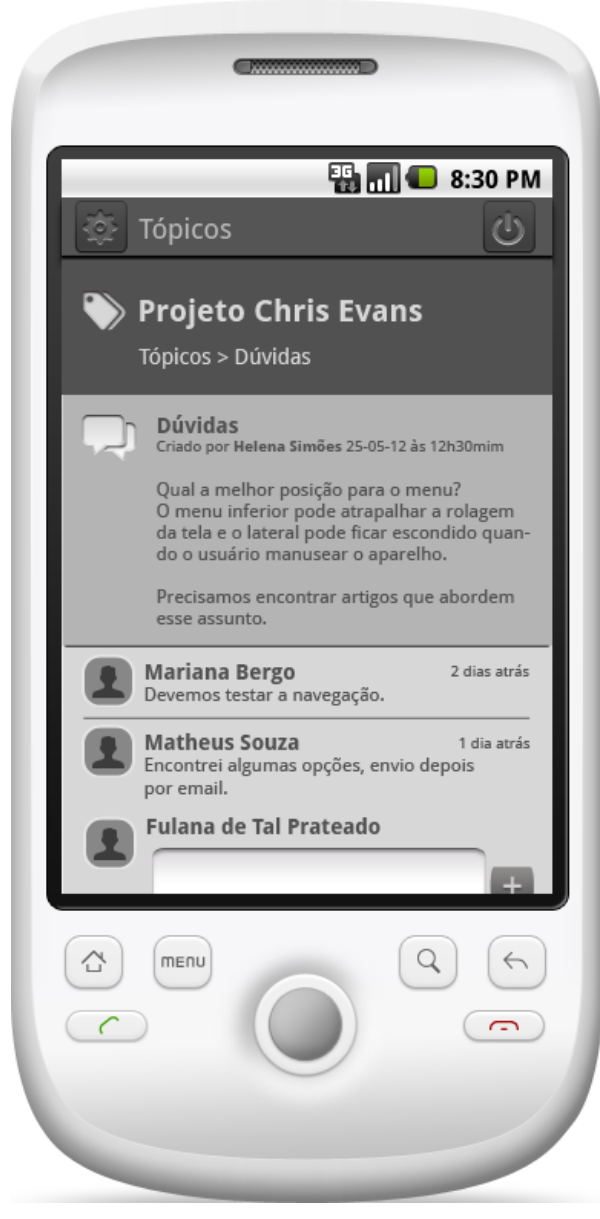

Figura 28: Representação da tela de fórum detalhado 


\section{Tela Criar Fórum}

Esta tela permite ao usuário criar um novo fórum de discussão contendo texto e, opcionalmente, anexar um arquivo.

- O campo "Título" tem a finalidade de adicionar um título curto e objetivo para o fórum a ser criado, facilitando a compreensão das pessoas que verão aquele fórum posteriormente. Campo de no máximo 50 caracteres.

- O campo "Texto" é o conteúdo inicial do fórum. Nele, o usuário colocará um assunto para discussão. Campo de no máximo 300 caracteres.

- O link "Upload” leva o usuário para um ambiente no qual é possível encontrar o conteúdo a ser adicionado

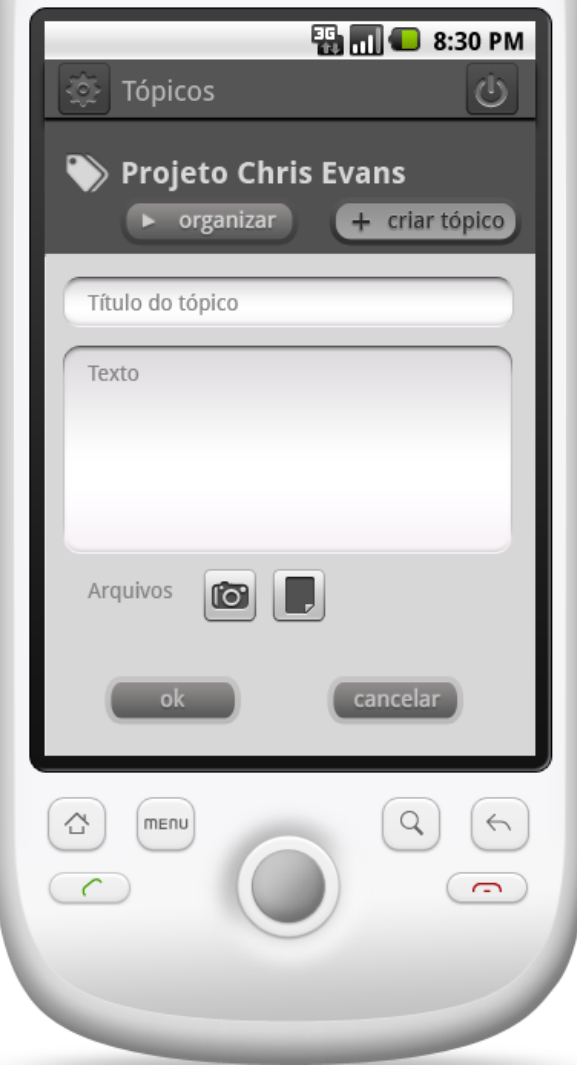

Figura 29: Representação da tela de criação de um novo fórum no celular, iniciar o processo no qual o arquivo passa para o banco de dados do aplicativo, nomeá-lo, descrevê-lo, e escolher o subgrupo prioritário. Os arquivos adicionados podem ser desde arquivos de texto até fotos, vídeos, áudios ou mesmo apresentações de slides.

- O link "Foto/Vídeo" tem ligação com a câmera do celular e, quando clicado, pode levar o usuário diretamente para a câmera, onde pode tirar uma foto ou fazer um vídeo e vinculá-lo ao fórum. 


\section{Tela Arquivos}

Esta tela proporciona ao usuário a visão de todos os arquivos referentes ao projeto e adicionados ao aplicativo. Os arquivos podem ser incluídos por meio de um fórum, no momento de sua criação. Os arquivos podem ser organizados por ordem de prioridade, subgrupo ao qual o usuário pertence, data em que foi postado e tipo ou nome do arquivo. A página contém os links

“Organizar”, "Criar Fórum”, “Configuração” e "Logout".

- O link “Organizar" abre um menu no qual é possível organizar os fóruns por ordem alfabética, ordem cronológica de criação, tipos de arquivo e por subgrupo.

- Ao clicar no link "Arquivo", o usuário é direcionado para a página "Fórum Expandido" de onde o link foi criado, onde existem todas as informações, arquivos e comentários relacionados a ele.

- O link "Criar fórum" leva o usuário para a tela de mesmo nome, onde é possível criar um fórum de discussão contendo título e texto descritivo, além de arquivos, adicionados a partir do próprio celular. 


\section{Tela Calendário}

Esta tela permite ao usuário visualizar um calendário que contém todos os eventos já cadastrados anteriormente. É possível comentálos e cadastrar novos eventos.

Os eventos deverão estar organizados de acordo com as preferências do usuário e listados em ordem cronológica. A página contém os links "Visualizar" (dia, semana, mês e ano), "Criar evento" e "Logout".

- O link "Visualizar" (dia, semana, mês e ano) proporciona ao usuário a opção de alternar a disposição do calendário de forma a mostrar os eventos disponíveis de acordo com a preferência do usuário. Será possível ter um tipo de visualização onde todos os dias do mês inteiro aparecem visíveis, como um outro

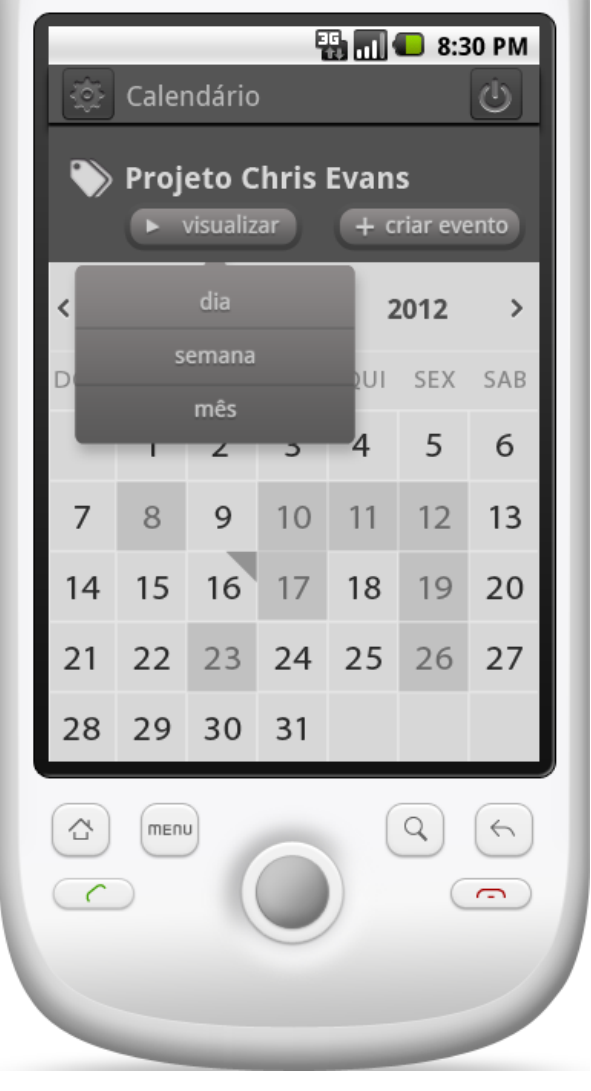

Figura 31: Representação da tela de calendário tipo onde os dias são divididos em grupos de sete, representando cada semana, entre outras visualizações padrão encontradas em aplicativos de calendário/agenda.

- O link “Criar evento" leva o usuário para um ambiente onde é possível criar um novo evento contendo título, data, hora, descrição, pessoas envolvidas e local. 


\section{Tela Evento Expandido}

Assim que o usuário clica em um dos eventos do calendário, o evento se expande dando lugar a informações referentes a ele, tais como título, data, descrição e local.

- O campo "Inserir Comentário" permite ao usuário fazer observações de no máximo 140 caracteres sobre o evento em questão. Assim que o usuário clica no campo o teclado se abre automaticamente.

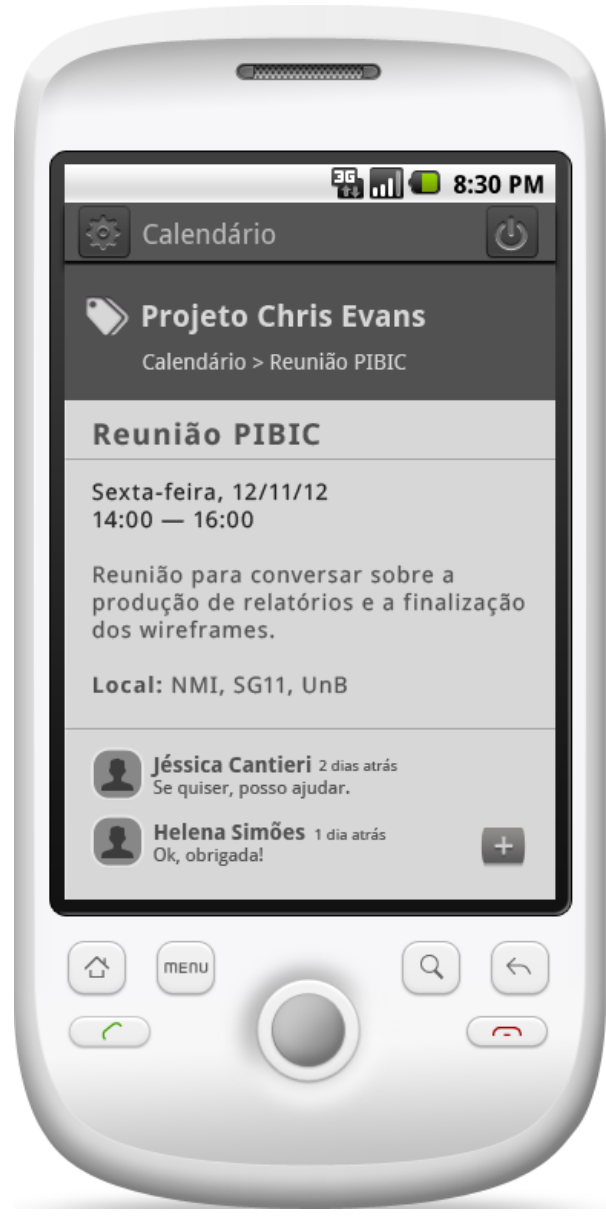

Figura 32: Representação da tela de evento detalhado 


\section{Tela Criar Evento}

Esta tela permite ao usuário adicionar um novo evento contendo título, período de realização e descrição e local.

- O campo "Título" tem a finalidade de adicionar um título curto e objetivo para o evento a ser criado, facilitando assim a compreensão das pessoas que vão ver aqueles eventos posteriormente. Campo de no máximo 50 caracteres.

- O campo "Prioridade" permite ao usuário definir, em uma escala de zero a três, a prioridade daquilo que está sendo criado, sendo zero a menor prioridade e três, a maior.

- O campo "Período de realização" permite ao usuário cadastrar o período de duração do evento, por meio da inserção de data e horário de início e término.

- O campo “Descrição" permite que o usuário escreva, em no máximo 300 caracteres, o objetivo do evento, os pontos a serem abordados no local ou outras informações relevantes.

- O campo "Local" tem uma limitação de 150 caracteres e serve para escrever o nome e endereço do local de encontro, para que as pessoas convidadas consigam chegar ao evento.

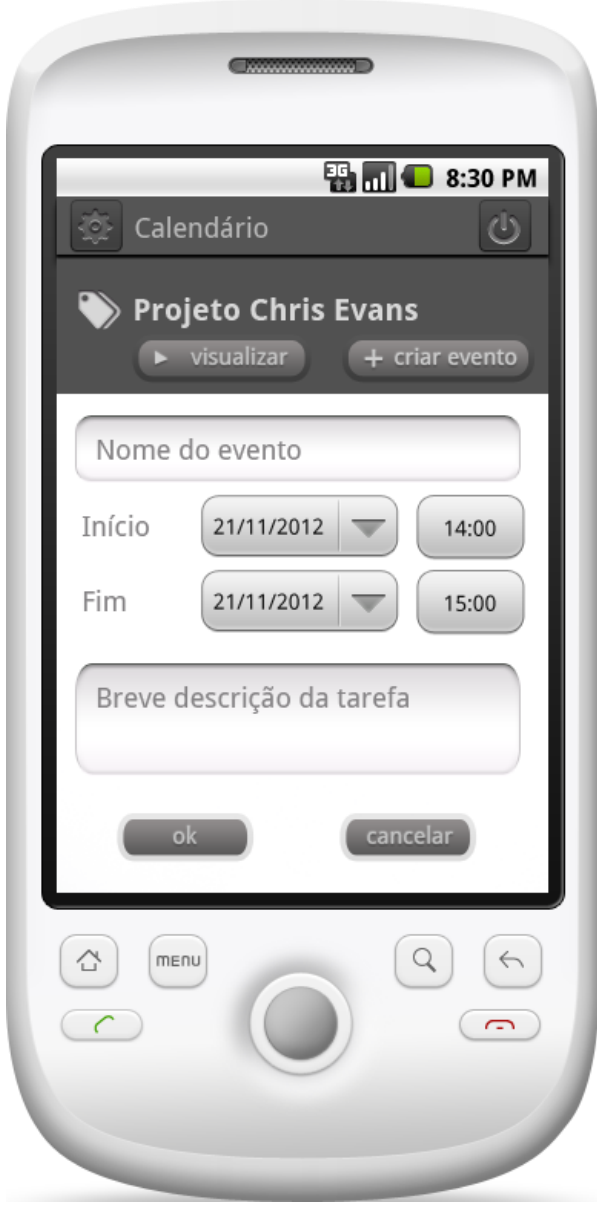

Figura 33: Representação da tela de criação de um novo evento 


\section{Tela Lista de Tarefas}

Esta tela permite que o usuário visualize as listas de tarefas anteriormente criadas, além de poder criar novas listas com novas tarefas. É possível, também, visualizar e adicionar comentários relacionados a cada lista de tarefa.

As listas serão organizadas por prioridade, pelo subgrupo ao qual o usuário pertence ou por data de criação da tarefa. A página contém os links "Criar lista de tarefas", "Mudar a Visualização" e "Logout".

- O link "Criar lista de tarefas" leva o usuário para um ambiente onde é possível criar uma nova lista na qual serão inseridas quantas tarefas sejam necessárias. Cada lista terá um título editável, assim como um objetivo a ser cumprido com o termino da realização de todas as tarefas, uma descrição da lista e de cada uma das tarefas, prazo para realização das atividades e links para documentos vinculados à realização tarefas.

- O link “Organizar” permite ao usuário o gerenciamento das listas, de modo que seja possível mudar a organização de acordo com filtros pré-definidos como prioridade das atividades, prazo de entrega, data de criação da lista, subgrupo ao qual a lista pertence, entre outros. 


\section{Tela Tarefa Expandida}

Assim que o usuário clica em uma das tarefas da lista, a tarefa se expande dando lugar a informações referentes a ela, tais como: título, prioridade, nome do criador, responsáveis por cada tarefa e descrição.

- O campo "Inserir Comentário" permite ao usuário fazer observações de no máximo 140 caracteres sobre a tarefa em questão. Assim que o usuário clica no campo o teclado se abre automaticamente.

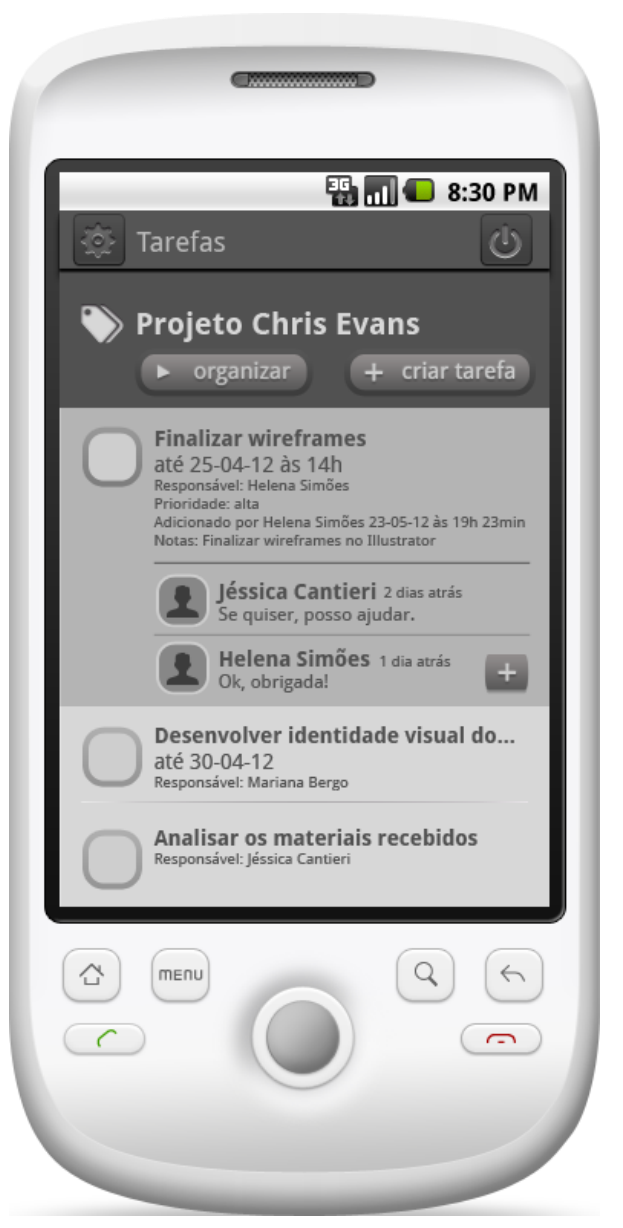

Figura 35: Representação da tela de tarefa detalhada 


\section{Tela Criar Tarefa}

Esta tela permite ao usuário adicionar uma nova tarefa contendo título, prioridade, nome do criador, responsáveis por cada tarefa e descrição.

- O campo "Título" permite ao usuário adicionar um título curto e objetivo para o evento a ser criado, facilitando assim a compreensão das pessoas que vão ver aquela tarefa posteriormente. Campo de no máximo cinquenta caracteres, limite que deve ser avisado ao usuário no texto de ajuda do campo (ou seja, no placeholder).

- O campo "Prioridade" permite ao usuário definir, em uma escala de zero a três, a prioridade daquilo que está sendo criado, sendo zero a menor prioridade e três, a maior.

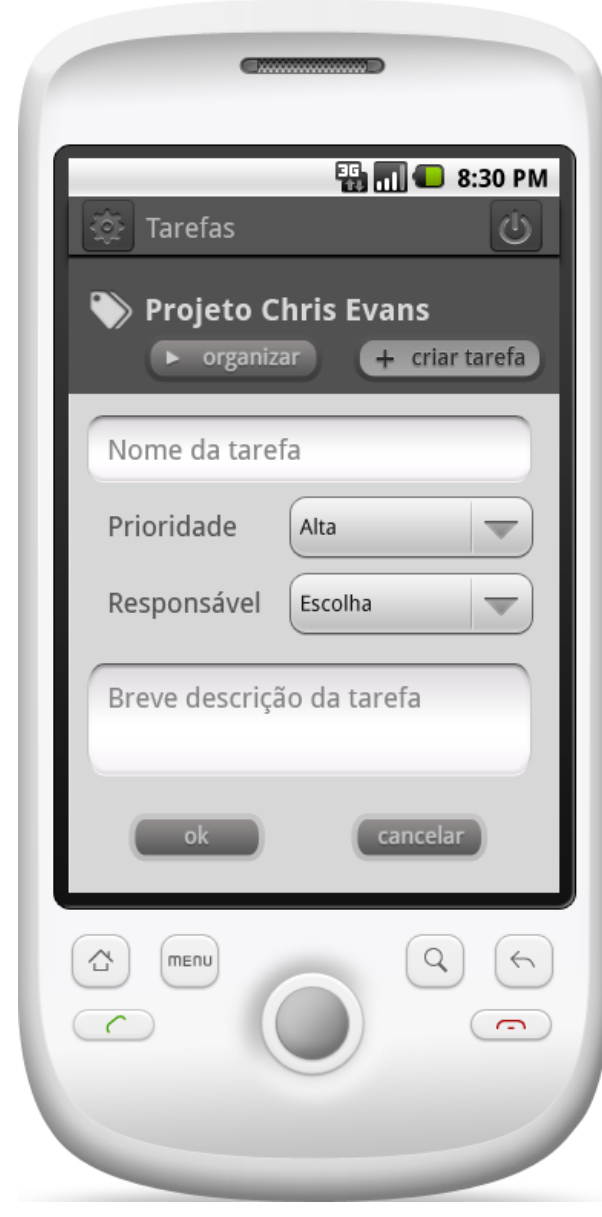

Figura 36: Representação da tela de criação de uma nova tarefa

- O campo "Responsáveis" permite ao usuário denominar que integrante do projeto é responsável por cada atividade a ser cumprida. Assim como é possível definir até quando aquilo deve ser realizado.

- O campo "Descrição" permite que o usuário escrever em no máximo 300 caracteres o objetivo da tarefa ou alguma outra informação que ele julgue necessária. 


\subsection{Análise da solução projetada}

Após estruturar e observar a solução projetada, já com a navegação e as telas do aplicativo visualmente planejadas, foi estudado posteriormente como o Tiê responde às mesmas questões norteadoras levantadas de acordo com o agrupamento da informação e usadas para análise das soluções existentes e disponibilizadas no mercado, descritas no Quadro 5.

\section{a) Fóruns}

Cada membro da equipe tem o aplicativo instalado em seu celular e pode criar seu próprio projeto, ou solicitar a participação em um já existente, a ser aprovado pelo líder do projeto. Uma vez dentro do ambiente, podem ser criados fóruns de discussão com ou sem arquivos ou eventos vinculados. Os outros participantes podem adicionar respostas dentro dos fóruns, em uma estrutura semelhante à de um fórum de discussão.

Também existe a possibilidade de se adicionar comentários às tarefas, criando fóruns de discussão vinculados a elas. O mesmo pode ocorrer com eventos e com um arquivo adicionado, sendo que este último também pode ser vinculado a fóruns de discussão.

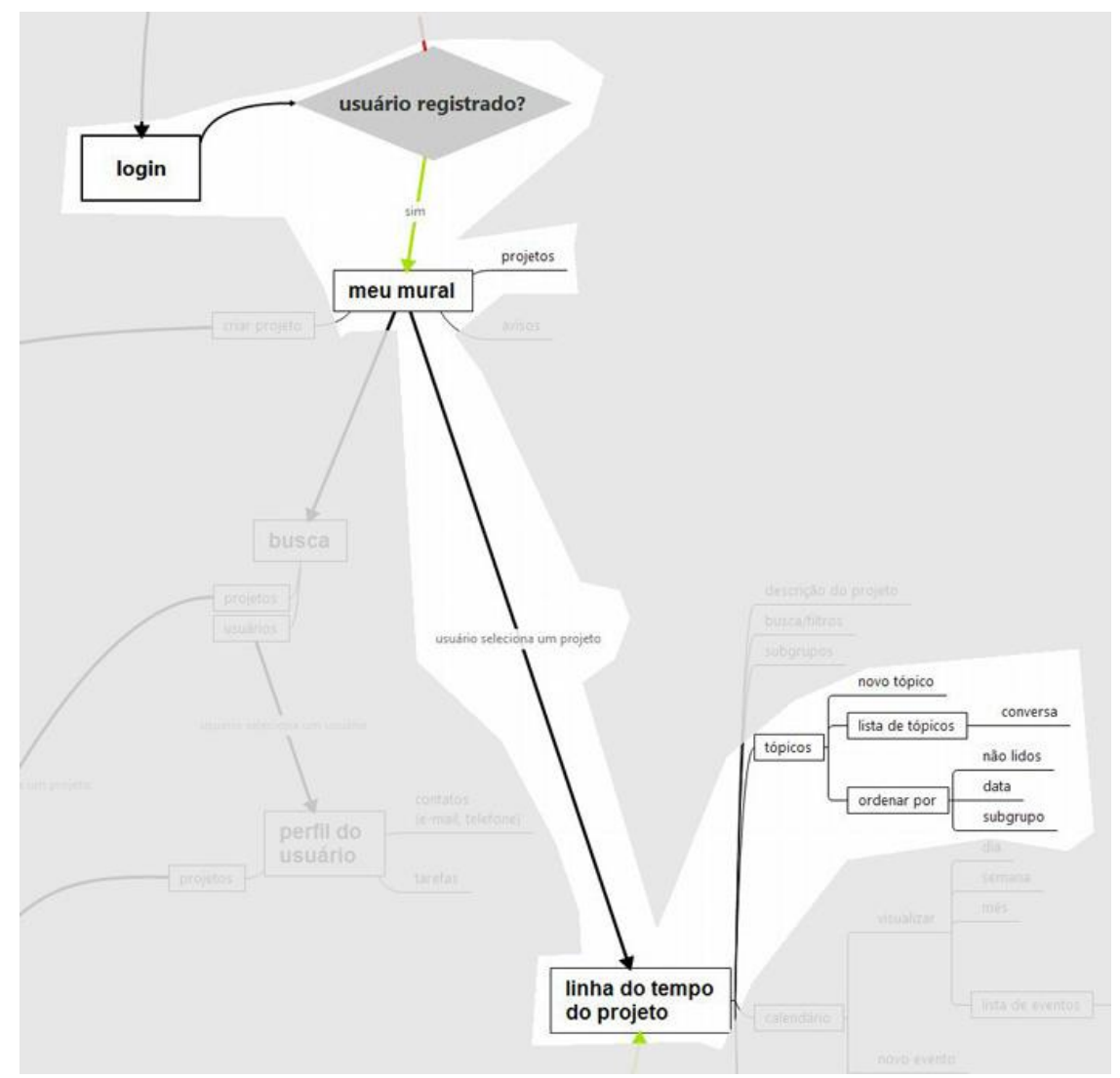

Figura 37: Recorte da arquitetura do Tiê, com foco na sequência de navegação para acesso aos fóruns 


\section{b) Tarefas}

Cada participante pode criar e se atribuir tarefas a partir das discussões realizadas em equipe, ou pode também ter tarefas atribuídas a ele pelo coordenador do projeto.

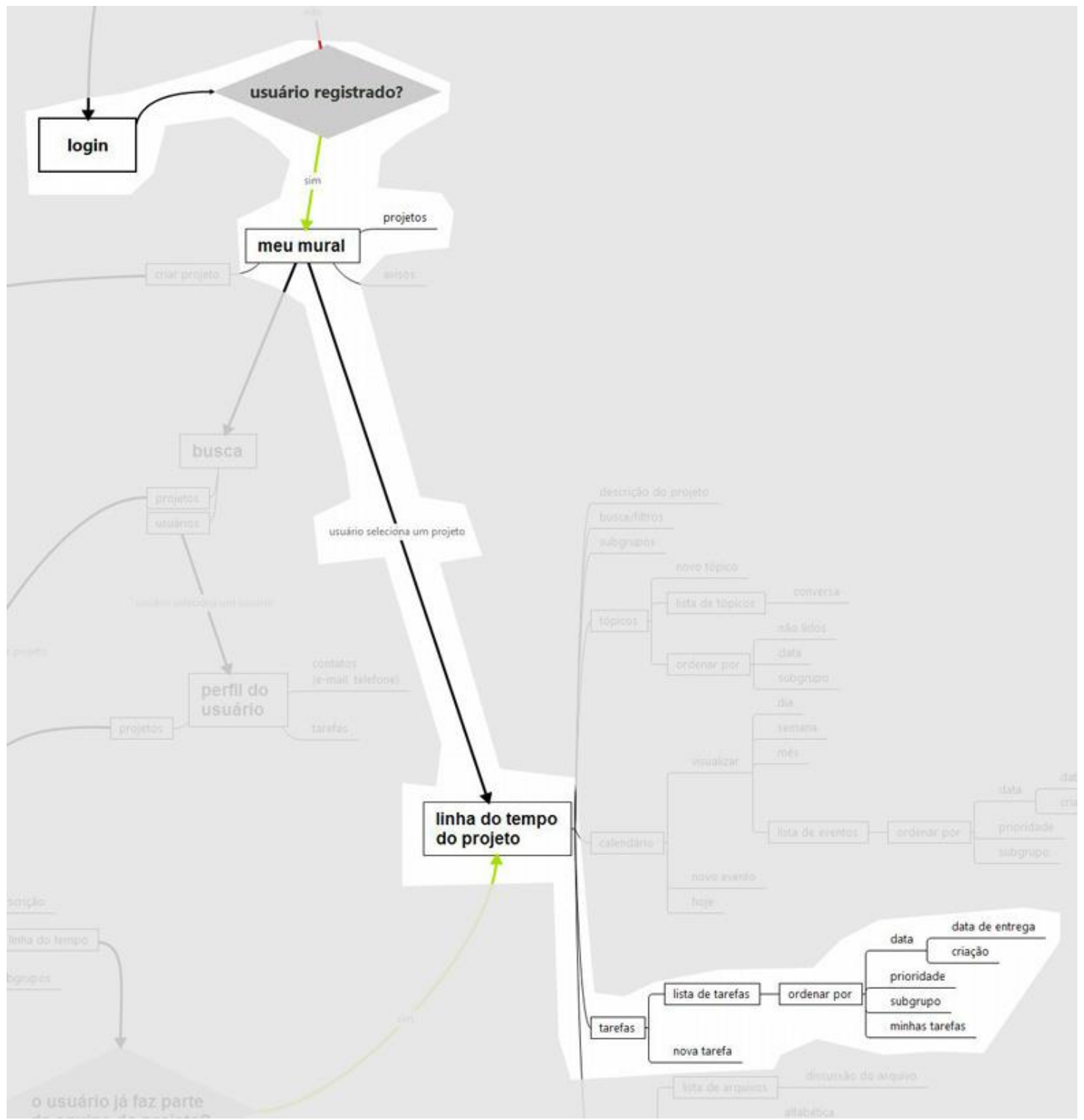

Figura 38: Recorte da arquitetura do Tiê, com foco na sequência de navegação para acesso às tarefas

$\mathrm{Na}$ área de tarefas é possível organizá-las por prioridade, subgrupo, data de criação ou finalização da tarefa, como observado na Figura 39. 

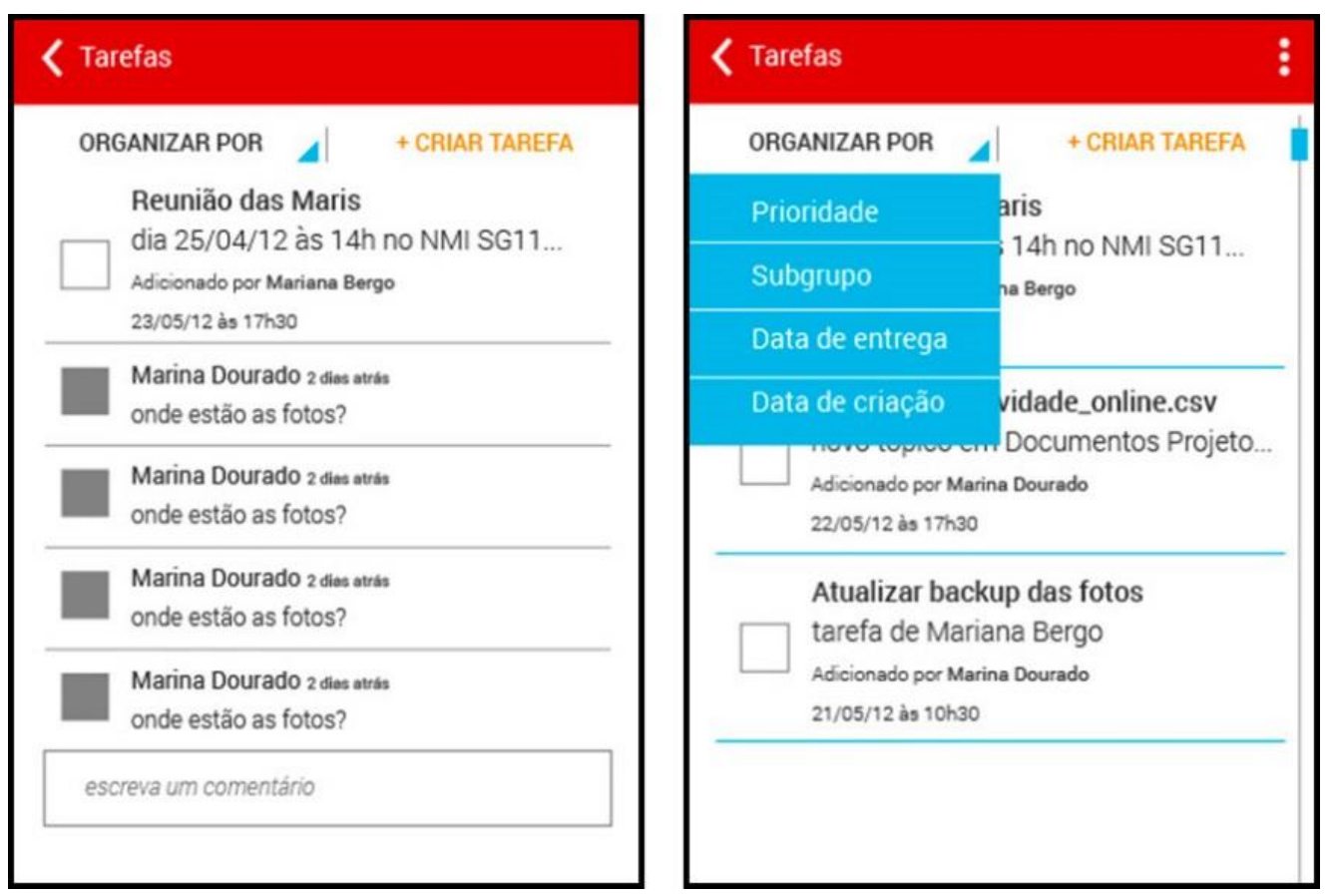

Figura 39: Exemplo de exibição dos comentários em uma tarefa (à esquerda) e do menu de organização da exibição de tarefas (à direita)

\section{c) Cronograma}

As datas de execução de cada tarefa são automaticamente adicionadas aos eventos, mas também há a possibilidade de se adicionar manualmente datas e eventos importantes relacionados ao projeto, como reuniões, workshops e seminários.

Pode-se também adicionar comentários aos eventos, criando fóruns de discussão vinculados a eles. 


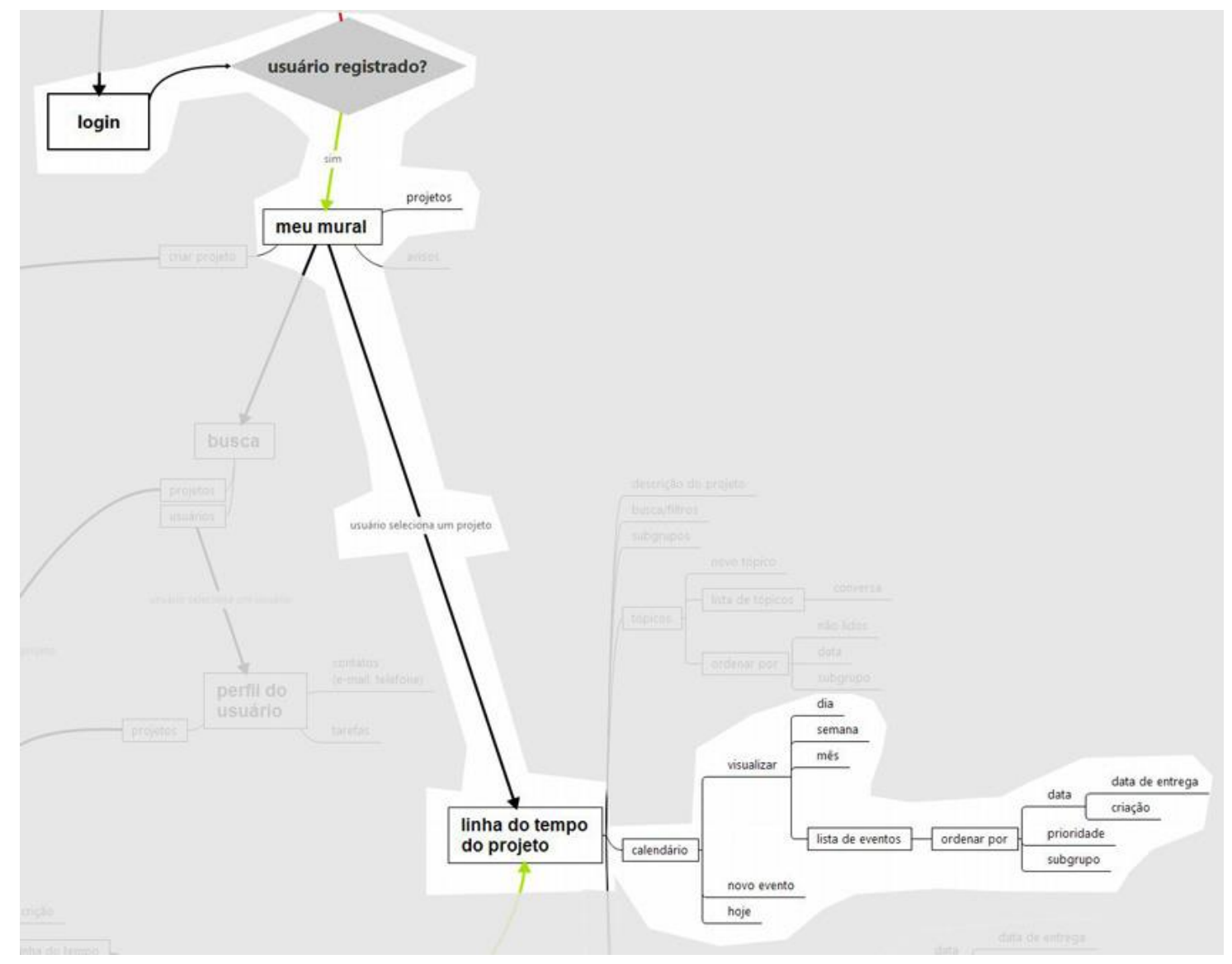

Figura 40: Recorte da arquitetura do Tiê, com foco na sequência de navegação para acesso aos eventos

\section{d) Arquivos}

Cada uma das divisões do menu lateral pode igualmente ser organizada de acordo com classificações que se apliquem àquelas informações, como, por exemplo, na tela de "Arquivos", na qual estes podem ser organizados por data de criação, por tamanho e por subgrupo aos quais estão relacionados.

Também existe a possibilidade de se adicionar comentários aos eventos, criando fóruns de discussão vinculados a eles. O mesmo pode ocorrer com eventos e com um arquivo adicionado, sendo que este último também pode ser vinculado a fóruns de discussão. 


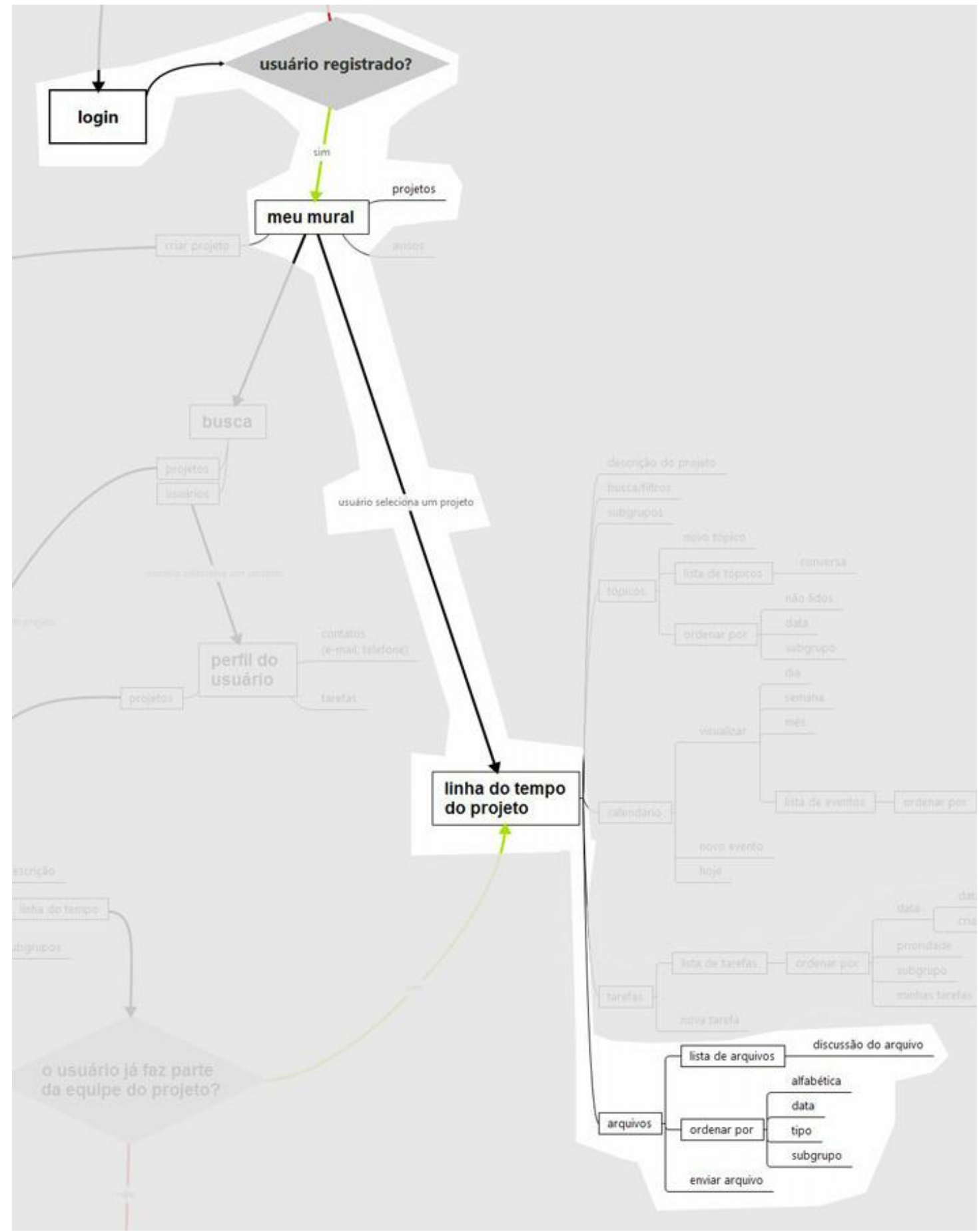

Figura 41: Recorte da arquitetura do Tiê, com foco na sequência de navegação para acesso aos arquivos

\section{e) Linha do tempo}

$\mathrm{Na}$ linha do tempo de um projeto criado no Tiê, ou seja, na página inicial de um projeto, podem ser observadas todas as trocas realizadas entre os usuários, em ordem cronológica da troca mais nova para a mais antiga. São registradas, além de todas as informações descritas acima, a entrada e saída de participantes do projeto. 


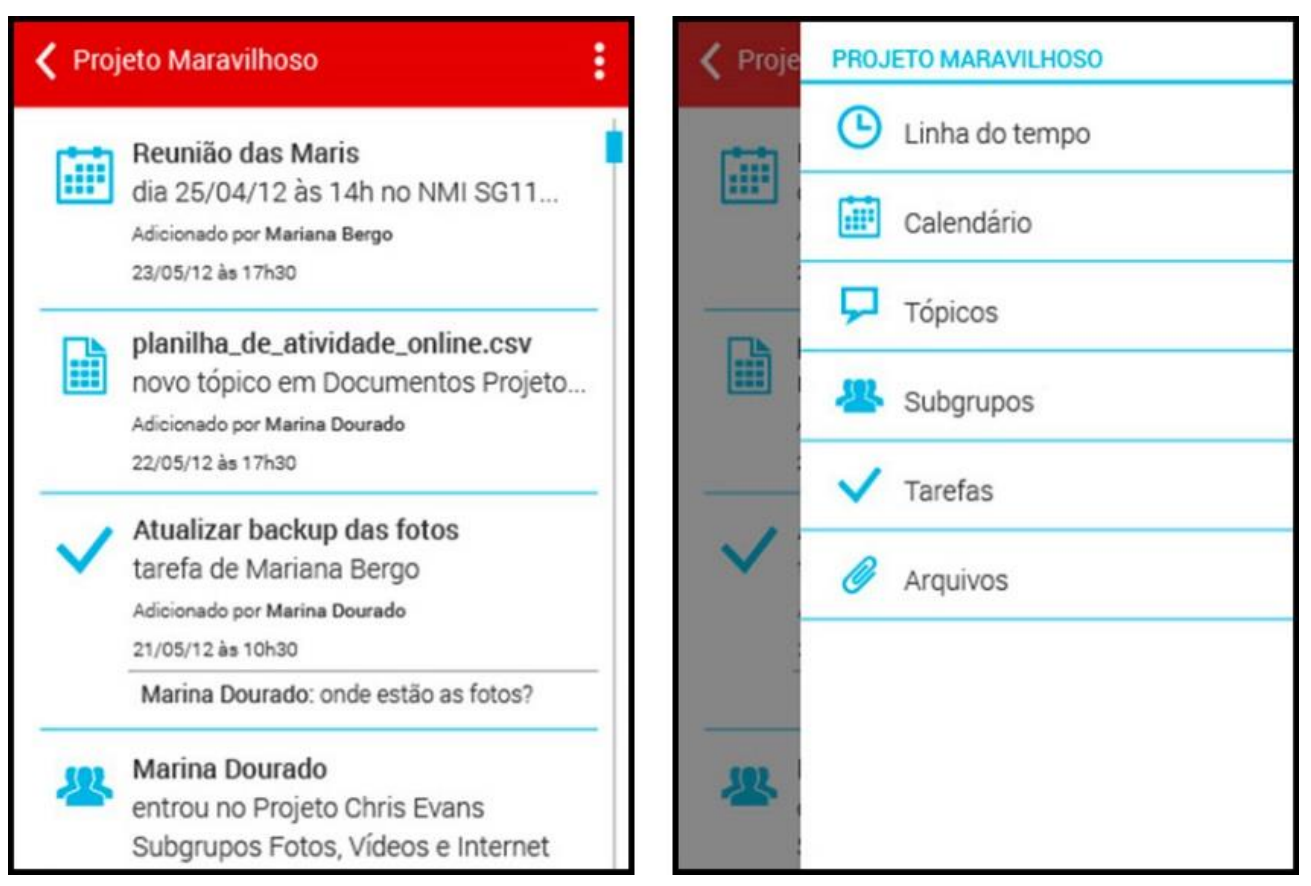

Figura 42: Exemplo de exibição da linha do tempo de um projeto no Tiê (à esquerda) e do menu lateral (à direita)

A figura 42 apresenta, à esquerda, a representação da tela quando o usuário desliza o dedo da borda direita da tela para o centro, revelando um menu lateral com as possibilidades de filtro das informações. Além da visão geral da linha do tempo, há a possibilidade de o aluno ver apenas as informações agrupadas que foram descritas no Quadro 1.

Optou-se por posicionar os filtros em um menu lateral para facilitar o acesso do usuário, que pode escolher a qualquer momento se deseja ter uma visualização completa do projeto ou se prefere visualizar informações específicas. Além disso, ele também pode observar o fluxo de informação por subgrupos, ou seja, por grupos menores dentro do grupo que estão trabalhando em etapas diferentes.

Dentro do menu lateral, quando o usuário seleciona uma das opções que não a "Linha do tempo", ele é levado para outra tela que lista todas as informações da opção selecionada.

Por fim, verificou-se a necessidade de projetar a tela inicial do aplicativo após o acesso do usuário. Optou-se por exibir tanto os projetos nos quais o aluno participa quanto avisos relacionados a eles. Esses avisos podem ser editados individualmente nas configurações quanto às preferências do usuário em recebê-los ou não, podendo ser enviados também por e-mail, caso deseje. Os avisos podem ser com relação a 
solicitações para ingressar no projeto, a eventos dos calendários dos projetos que participa, a novas tarefas designadas ao aluno e a comentários em fóruns criados por ele.

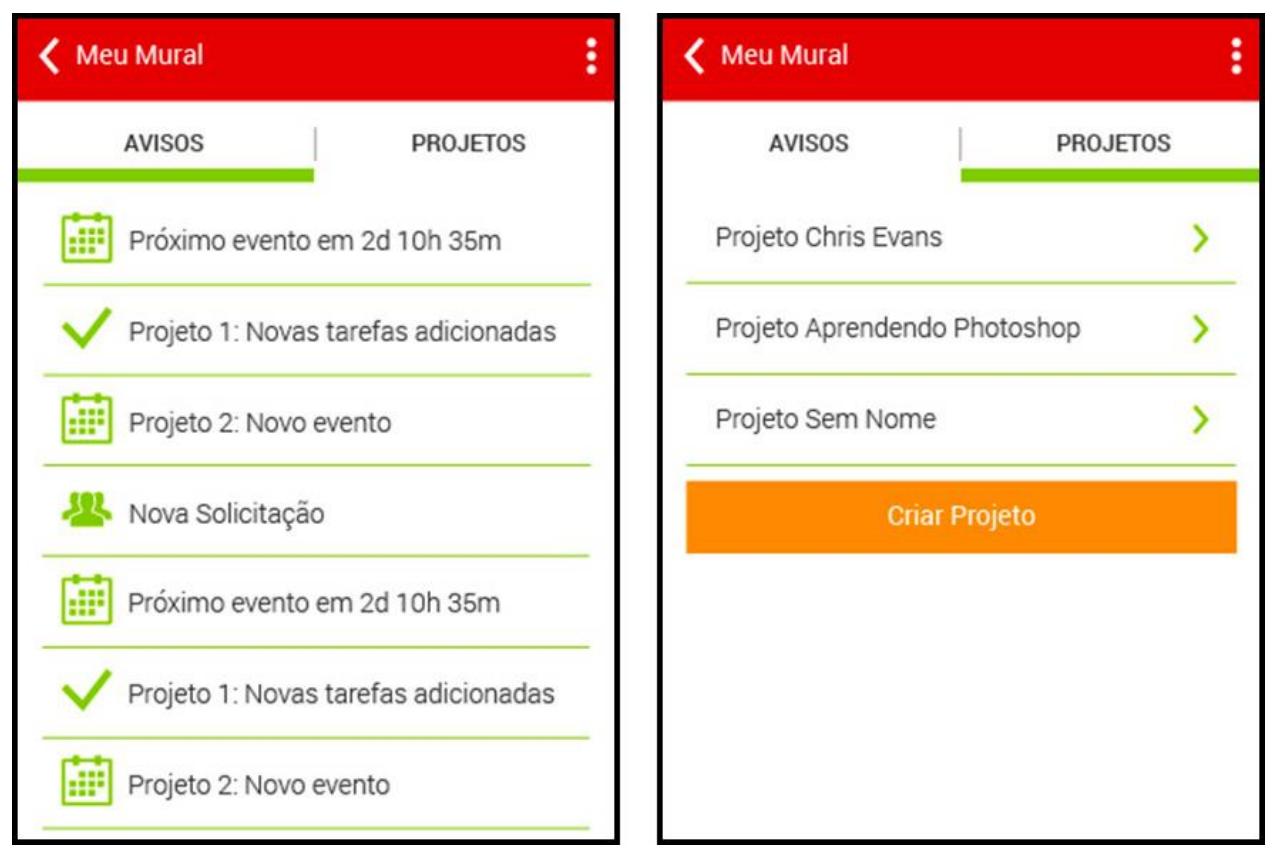

Figura 43: Exemplo de exibição da tela de avisos (à esquerda) e da tela de projetos (à direita)

A solução encontrada ao longo da concepção do Tiê envolve agrupar informações relevantes ao projeto em diferentes categorias de informação, permitindo que o usuário as filtre ou visualize o projeto por inteiro, caso deseje. As informações nunca são omitidas por padrão: o usuário deve optar pelos filtros no momento que julgar adequado.

\subsection{Validação dos termos utilizados na solução desenvolvida}

Em paralelo à análise da solução projetada quanto aos requisitos, o Tiê também estava sendo desenvolvido pela equipe de pesquisadores. Porém, um problema foi identificado: os termos usados no aplicativo poderiam gerar dúvidas aos usuários finais, pois a equipe de pesquisa e desenvolvimento havia determinado um vocabulário para as ações e para o gerenciamento do projeto, processo que não contou com a validação dos usuários. Por isso, havia dúvida quanto a esses termos fazerem sentido em outros contextos de desenvolvimento de projetos colaborativos.

Assim, foi concebida uma maneira de realizar a validação dos termos quanto à acessibilidade, baseando-se na técnica de cardsorting para ir além do que se realiza costumeiramente para construir um "vocabulário controlado", termo utilizado dentro do 
campo da arquitetura da informação para representar o conjunto de termos usados no sistema (SANTA ROSA, MORAES, 2012). Garrett (2003 apud SANTA ROSA, MORAES, 2012), sugere que este vocabulário deve refletir a linguagem dos usuários de forma a evitar que os jargões, ou, no caso desta pesquisa, os termos usados pelo grupo de pesquisa e desenvolvimento, confundam os usuários.

A dinâmica elaborada teve o objetivo de validar os termos quanto à sua compreensão por pessoas de outros contextos de desenvolvimento de projetos colaborativos. Desta forma, foram selecionados cinco estudantes de graduação e uma pessoa já graduada para realizarem a avaliação dos termos, sendo que todos participam ou já participaram de projetos colaborativos.

Para conhecer o perfil destes participantes, foi elaborado um questionário, disponível no Anexo V. Com base na análise das respostas, disponíveis no anexo VI, observou-se que 33,3\% deles usa smartphone Android, sistema operacional no qual o ambiente está sendo desenvolvido atualmente. Três pessoas utilizam smartphones da marca Apple e as outras têm celulares das marcas Samsung, Motorola e Nokia. Estas informações são importantes para compreender os padrões de navegação aos quais eles estão acostumados, o que interfere na percepção individual dos termos utilizados na navegação destes sistemas operacionais.

Sobre o uso de smartphones, $16,7 \%$ são usuários experientes, que têm mais de três anos de uso deste tipo de dispositivo. Com relação aos aplicativos, todos utilizam Gmail e Whatsapp para comunicação, e 83\% o Facebook Messenger.

\begin{tabular}{|l|r|r|}
\hline Whatsapp & 6 & $100,00 \%$ \\
\hline Gmail & 6 & $100,00 \%$ \\
\hline Facebook Messenger & 5 & $83,33 \%$ \\
\hline SMS & 2 & $33,33 \%$ \\
\hline Trello & 2 & $33,33 \%$ \\
\hline Viber & 1 & $16,67 \%$ \\
\hline Slack & 1 & $16,67 \%$ \\
\hline Outlook & 1 & $16,67 \%$ \\
\hline
\end{tabular}

Tabela 1: Aplicativos usados pelos participantes para comunicação e gerenciamento de tarefas e/ou projetos no celular 
Além disso, duas pessoas atuam na área da Computação, igual número atua na área de Design, uma pessoa atua na área de Comunicação e a outra atua na área de Administração. Em perguntas abertas, foi questionado quais ferramentas colaborativas elas utilizam para trabalhar em projetos em grupo: os mais utilizados são as ferramentas do Google e do Trello, mas alguns usuários não utilizam a versão móvel deste último, sendo que um deles respondeu que é "muito bagunçado e de difícil navegação", ou seja, por mais que a ferramenta seja importante para o usuário, a acessibilidade é importante para mantê-lo motivado a utilizar o ambiente.

Essa atividade foi conduzida no Núcleo de Multimídia e Internet dentro de um período de duas horas e meia, sendo dividida em quatro etapas: a primeira teve a duração de vinte minutos e consistiu na explicação aos participantes da importância do processo de validação da linguagem, ou seja, dos termos utilizados em um sistema para a compreensão pelos usuários, além do valor da participação deles nesse processo, reforçando o objetivo da avaliação. Para situá-los quanto aos termos, foi explicado o projeto do ambiente, desde a concepção do nome, Tiê, até suas possibilidades de uso dentro de grupos colaborativos. Com vistas à melhor compreensão e à inserção dos participantes na explicação, foram dados exemplos utilizando como base os perfis das próprias pessoas que estavam na sala, criando uma narrativa na qual cada um tinha uma função específica no projeto e como eles poderiam usar o aplicativo.

A segunda etapa consistiu na observação dos termos individuais usados no aplicativo pelos participantes. Antes da chegada deles, as palavras já haviam sido impressas em folhas separadas e coladas nas paredes da sala, com espaçamento entre elas. Não havia ligação aparente entre as palavras, que foram embaralhadas e coladas aleatoriamente para que os participantes não fossem previamente contaminados pela organização original da hierarquia da estrutura dos termos. 


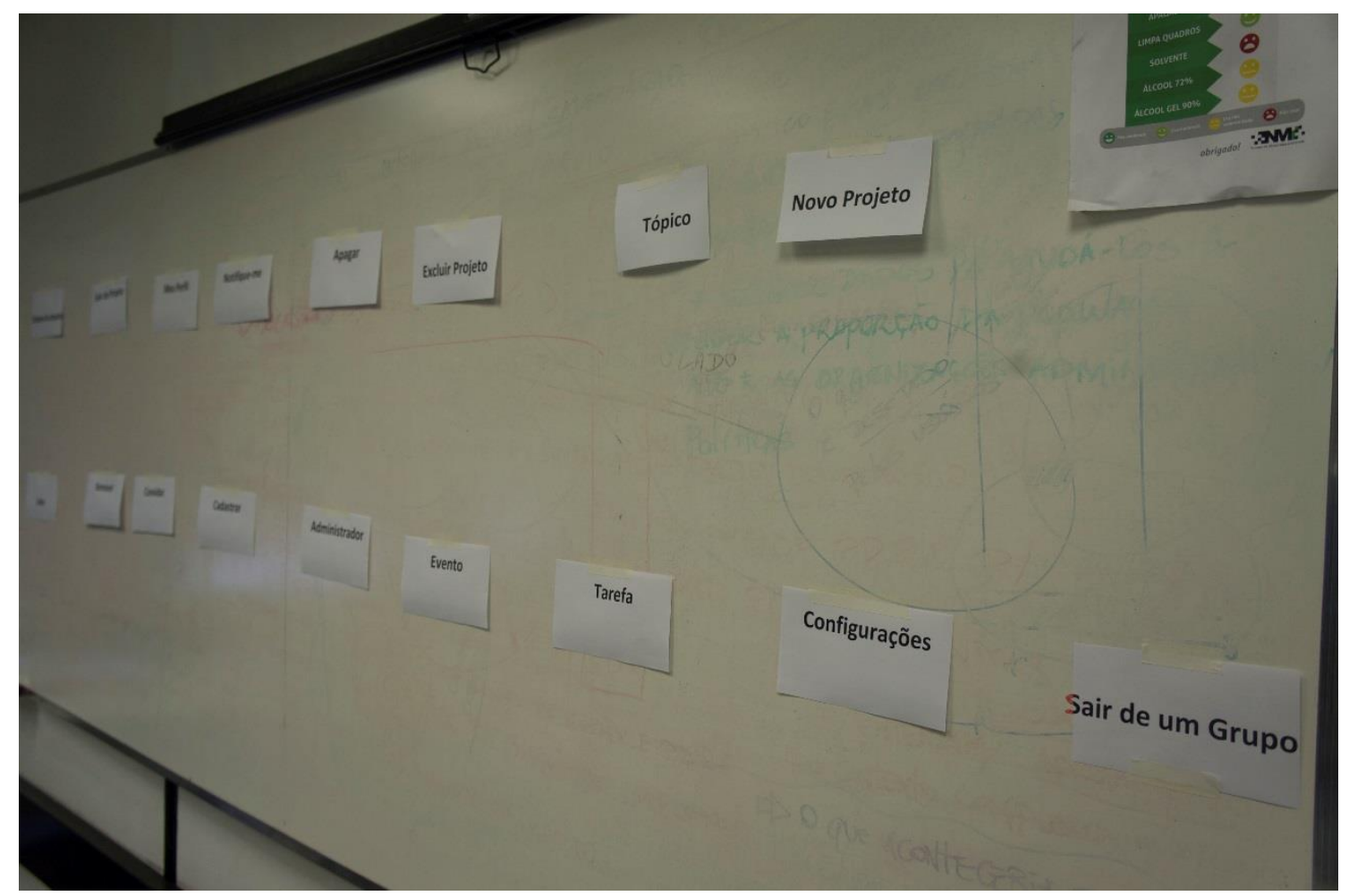

Figura 44: Disposição dos termos utilizados no sistema para validação

No total, foram impressos 45 termos usados em menus, textos para o usuário e botões de ação. Logo, foram distribuídas folhas separadas e menores aos participantes, solicitando a todos que escrevessem o significado individual do máximo de termos que conseguissem dentro de 20 minutos. Estas palavras, listadas no Quadro 5, deveriam ser explicadas cada uma em um pedaço de papel separado, de maneira a explicar o significado e/ou a ação relacionado ao termo.

Quadro 6: Listagem dos termos utilizados no ambiente e selecionados para validação

\begin{tabular}{|l|l|l|l|l|}
\hline Projetos & Tipo & Participante & $\begin{array}{l}\text { Nomear } \\
\text { Administrador }\end{array}$ & Novo Arquivo \\
\hline Notificações & $\begin{array}{l}\text { Nova } \\
\text { postagem }\end{array}$ & Administrador & Excluir Projeto & Remover \\
\hline $\begin{array}{l}\text { Novo } \\
\text { projeto }\end{array}$ & Atualizar & Coordenador & Pesquisar & $\begin{array}{l}\text { Serviço de } \\
\text { armazenamento }\end{array}$ \\
\hline $\begin{array}{l}\text { Meus } \\
\text { projetos }\end{array}$ & Anúncio & Convidar & Meu Perfil & $\begin{array}{l}\text { Sistema de } \\
\text { arquivo }\end{array}$ \\
\hline
\end{tabular}




\begin{tabular}{|l|l|l|l|l|}
\hline Ações & Tópico & Sair de um grupo & Meus Arquivos & $\begin{array}{l}\text { Adicionar } \\
\text { arquivos }\end{array}$ \\
\hline Timeline & Tarefa & Sair do Projeto & Configurações & Cloud \\
\hline Info & Arquivo & Novo grupo & Editar & Associar conta \\
\hline Grupo & Evento & $\begin{array}{l}\text { Nomear } \\
\text { coordenador }\end{array}$ & Apagar & Notifique-me \\
\hline $\begin{array}{l}\text { Tarefas } \\
\text { adicionais } \\
\text { do usuário }\end{array}$ & Links & Compartilhar & Cadastrar & Concluir \\
\hline
\end{tabular}

Transcorrido o tempo determinado, cada participante colou sua descrição abaixo do termo correspondente na parede. Alguns termos ficaram sem descrição, e outros, com apenas uma. Dessa forma, foi proposta uma terceira etapa individual com duração de dez minutos para descrever primeiramente os sete termos que ficaram sem descrição, e posteriormente os termos que tivessem apenas uma descrição.

Novamente, ao final do tempo estipulado, os participantes colaram as novas descrições debaixo dos termos que faltavam. Assim, todos os termos contavam com pelo menos uma descrição. Todos permaneceram em pé, observando o resultado das etapas posteriores, e então foi solicitado que os participantes falassem os termos que eles acharam mais complexos para descrever, de forma a iniciar a quarta etapa, que consistiu na discussão, durante uma hora e quinze minutos, sobre as percepções deles quanto aos termos. 


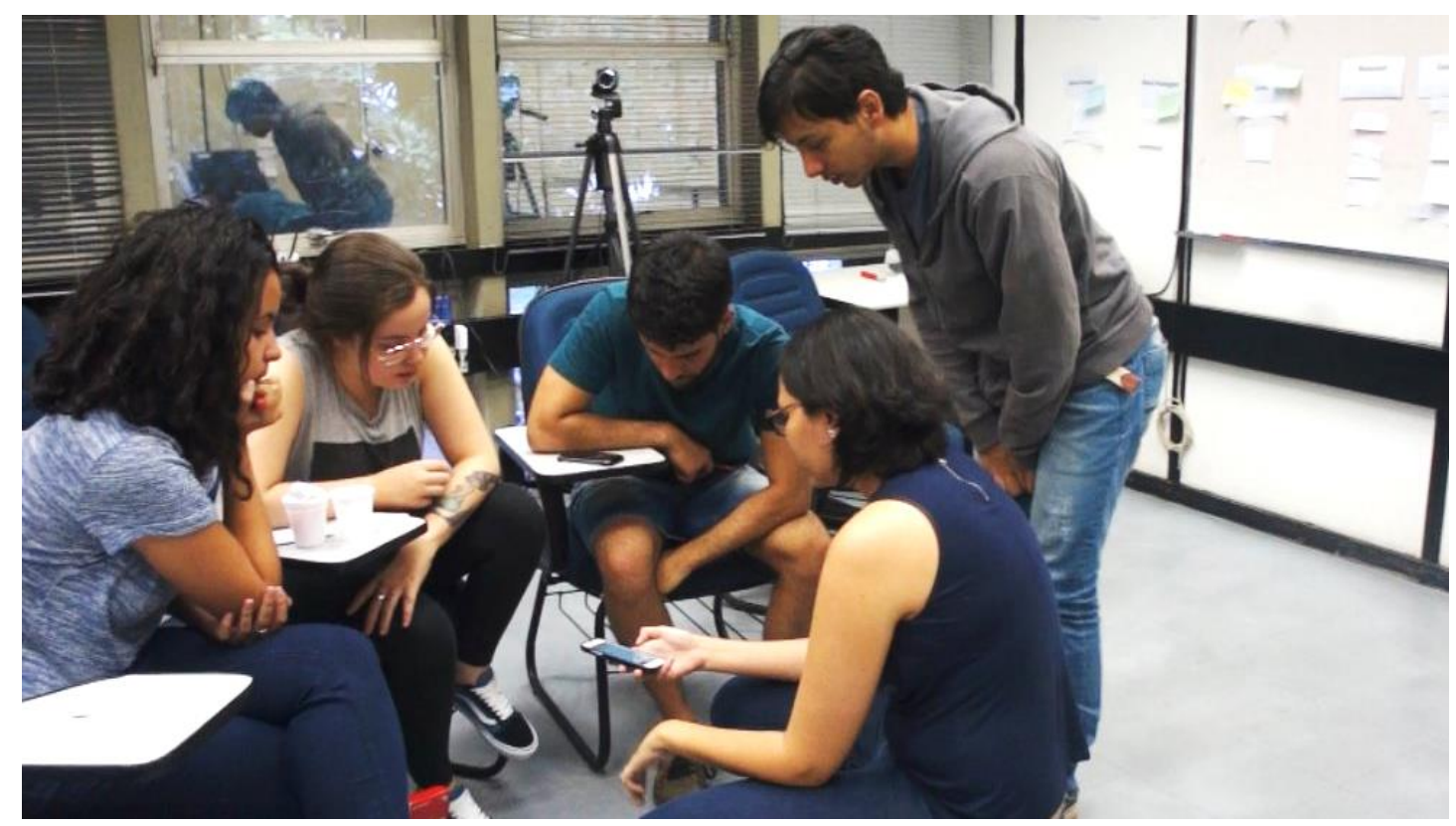

Figura 45: Discussão dos termos em conjunto após a definição individual pelos participantes

Nesse período também foram estimulados a sugerir quais os termos que seriam mais adequados no lugar dos termos atuais, de forma que fizesse sentido às atividades que poderiam ser desempenhadas. Quando os participantes tinham dúvidas com relação aos termos no contexto do aplicativo, eram mostradas as telas dentro do aplicativo desenvolvido, ressaltando sempre que as palavras apresentadas não eram definitivas e que eles tinham liberdade para propor termos que fizessem mais sentido e fossem melhor compreendidos.

\subsection{Análise dos resultados obtidos na fase de avaliação}

Dos termos apresentados aos participantes, quatorze palavras geraram maior discussão: “Anúncio”, “Associar conta", “Atualizar", "Info”, “Tópico”, "Nova postagem”, "Novo grupo", "Sistema de arquivo", "Tarefas adicionais do usuário", “Tipo", “Administrador", "Coordenador", e os termos em inglês "Links", "Cloud" e "Timeline". A respeito do termo "Novo grupo", os participantes associaram a palavra "grupo" a "projeto", tratando-as como sinônimos. A equipe de desenvolvimento explicou, então, que o vocábulo era utilizado como uma subdivisão do projeto, ou seja, a divisão do projeto em grupos menores, cada um responsável por uma etapa. Foi dado o exemplo do desenvolvimento do Veículo Elétrico, que tinha inicialmente equipes responsáveis pela parte mecânica, pela parte elétrica e pelo design automotivo, mas todos faziam parte do 


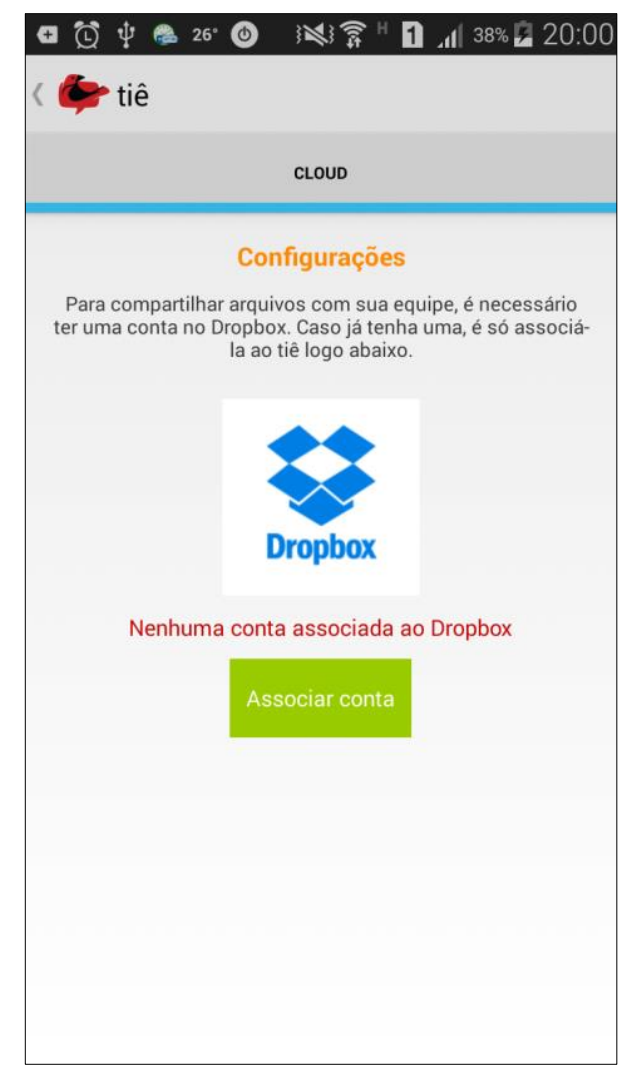

Figura 46: Imagem do botão de ação "Associar conta" mesmo projeto. Após a discussão de todos os envolvidos na validação do termo, sugeriu-se renomear esse termo como "Novo subgrupo" ou "Novo núcleo", vocábulos que, para o grupo, representavam melhor a ideia.

Sobre o vocábulo "Associar conta", houve dúvida geral quanto ao significado fora de contexto. Apenas um dos participantes descreveu o termo como "[possibilidade de] mais de uma pessoa usar a mesma conta"; o restante não soube falar o que o termo poderia significar. Desta forma, a equipe mostrou a tela desenvolvida com o botão em destaque, como mostra ao lado. Após verem a tela, os participantes disseram que entenderam o termo e que ele era adequado. Porém, em vez de “Cloud”, eles sugeriram que a área poderia se chamar "Gerenciamento de contas". Caso o

termo devesse ser utilizado em algum outro momento, em outra área ou em um texto explicativo para o usuário, foi sugerido o termo "Compartilhamento na nuvem" como tradução.

A respeito de "Sistema de arquivo", os participantes definiram o termo como "maneira como os arquivos serão anexados e divulgados e distribuídos na plataforma" ou “extensão de arquivos", como .pdf ou .jpg. Foi explicado que os arquivos são enviados diretamente ao Tiê: eles ficam hospedados em um sistema de armazenamento de arquivos que o usuário tenha, sendo que no momento há somente integração com o Dropbox, e depois o usuário compartilharia um atalho (ou um "link") dentro do projeto. Assim, o sistema de arquivo seria o serviço de armazenamento em nuvem no qual o arquivo está de fato. Foi proposto o termo "Repositório" por um dos participantes, mas após a discussão, percebeu-se que esse termo também não seria compreendido por todos. Uma das pessoas da equipe de desenvolvimento perguntou "Como vocês chamam esses serviços, tipo Google Drive, Dropbox etc? ”, um dos participantes da 


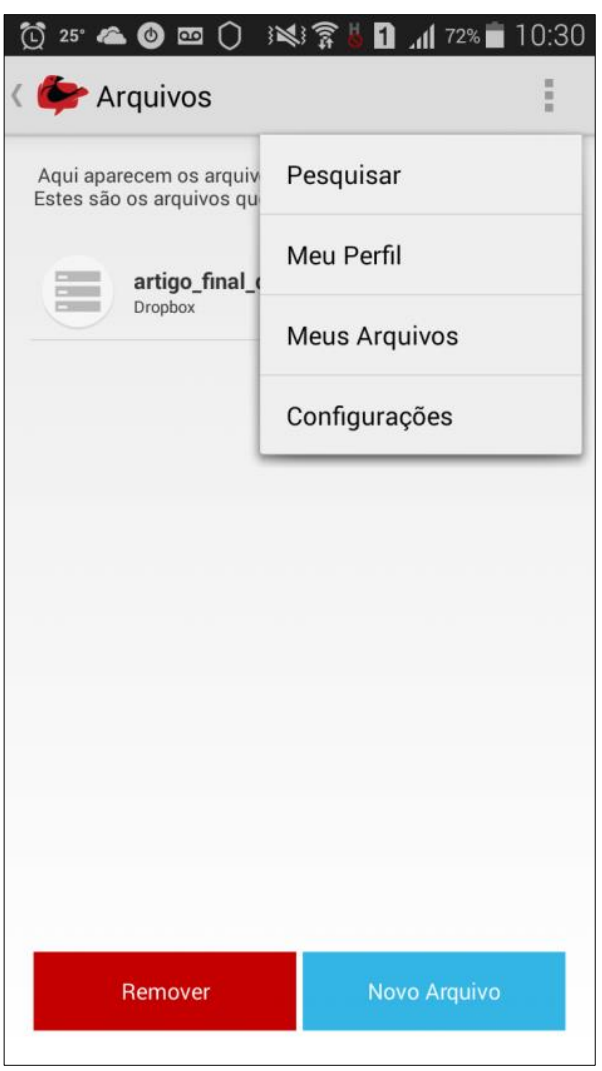

Figura 47: Captura da tela "Meus arquivos" dentro do ambiente validação respondeu "Gerenciador de arquivos", termo que os outros também julgaram coerente.

Ainda sobre o compartilhamento de arquivos, o termo "Links" era usado na frase "Aqui aparecem os arquivos para os quais você gerou links. Estes são os arquivos que você pode compartilhar com sua equipe". Esta frase aparecia dentro da área "Meus arquivos", acessível por meio do menu superior direito. Sobre a área, os participantes da validação sugeriram os termos "Arquivos linkados", ou "Seus arquivos no Tiê" após um dos membros da equipe de desenvolvimento questionar " $\mathrm{O}$ que aconteceria com os arquivos no Tiê caso vocês os deletassem do Dropbox? ". Nesse caso as pessoas responderam que o link do Tiê ia parar de funcionar, o que de fato ocorreria, ou

seja, o conceito foi entendido pelos participantes da validação.

Sobre os termos em inglês, todos compreenderam o que significam, mas eles também concordaram que devido ao fato de o aplicativo ser em língua portuguesa, eles deveriam estar melhor contextualizados, de preferência traduzidos ao português. Eles sugeriram que "Timeline" não fosse traduzido como "Linha do tempo", pois não há a representação figurativa de pontos relacionados a determinados períodos de tempo no Tiê. Em vez disso, eles optaram pelo termo "Mural", no qual estariam listados todos os envios da equipe do projeto.

Em relação a "Tarefas adicionais do usuário", os participantes descreveram o vocábulo como "ações que nem todos os usuários têm acesso", "deveres do usuário", "mais funções a serem realizadas", e "tarefas que não estão em nenhum projeto, tarefas pessoais". Foi explicado que, quando o usuário busca por outra pessoa, acessando o perfil dela, surgem informações relativas a ela, tais como informações de contato, listagem dos projetos que ela participa e tarefas pelas quais ela está responsável. O termo "Tarefas adicionais do usuário" representaria, então, as tarefas que a pessoa buscada tenha em outros projetos, mas que o usuário que está buscando não tem acesso, 
pois não participa destes outros projetos e consequentemente não tem permissão para ver estas tarefas. Assim, abaixo do título "Tarefas adicionais do usuário" apareceria apenas "12 tarefas em outros projetos" por exemplo, de forma a ver se ele está sobrecarregado com atividades além dos projetos nos quais eles participam juntos. Apesar da compreensão da ideia, houve dificuldade em propor outro termo. Dentre os vocábulos propostos, destacam-se "Outras tarefas do usuário" e "Mais tarefas".

Com relação ao termo "Atualizar", os participantes o associaram a "atualização do aplicativo", "editar" ou "manter as notícias e informações importantes no topo da página para serem vistas de uma maneira mais fácil”. Dentro do ambiente, a palavra é um botão dentro de um grupo para atualizar a tela na qual o usuário se encontra, com o objetivo de mostrar possíveis novos envios de conteúdo feitos por colegas de projeto. Os participantes da validação acharam estranho haver um botão para essa ação, já que eles a executam sem pensar muito ao utilizar o Twitter, Facebook, Gmail e outros aplicativos, em um movimento de deslizar a tela para baixo a partir do topo. Eles

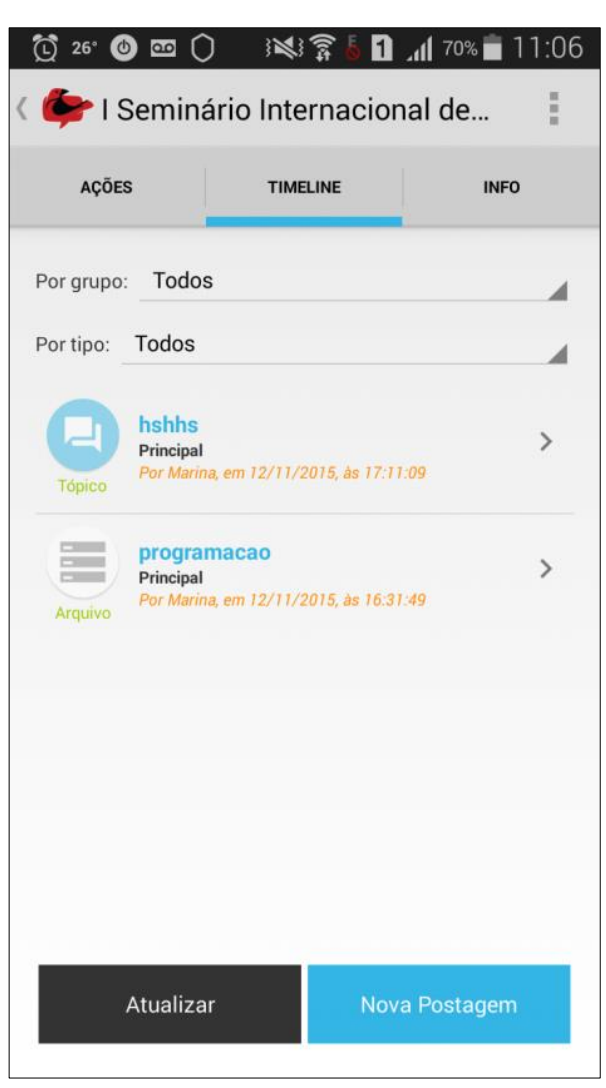

Figura 48: Captura de tela do mural do projeto dentro do ambiente disseram que, caso fosse necessário haver um botão, ele poderia ser mais específico, como "Atualizar página".

O termo "Info" foi descrito como "informações sobre o sistema, tarefa ou projeto", "informação necessária para esclarecer o usuário e facilitar o entendimento", e "ajuda sobre algo", ou seja, os participantes compreenderam o vocábulo como uma informação complementar sobre um item específico do ambiente. Foi explicado que "Info" era o nome da área onde estão a descrição do projeto e as listagens dos subgrupos e de participantes. Eles disseram que dentro do contexto era compreensível o termo como "informações do projeto", que poderia ser assim expandido para clarificar ainda mais o que contém. 


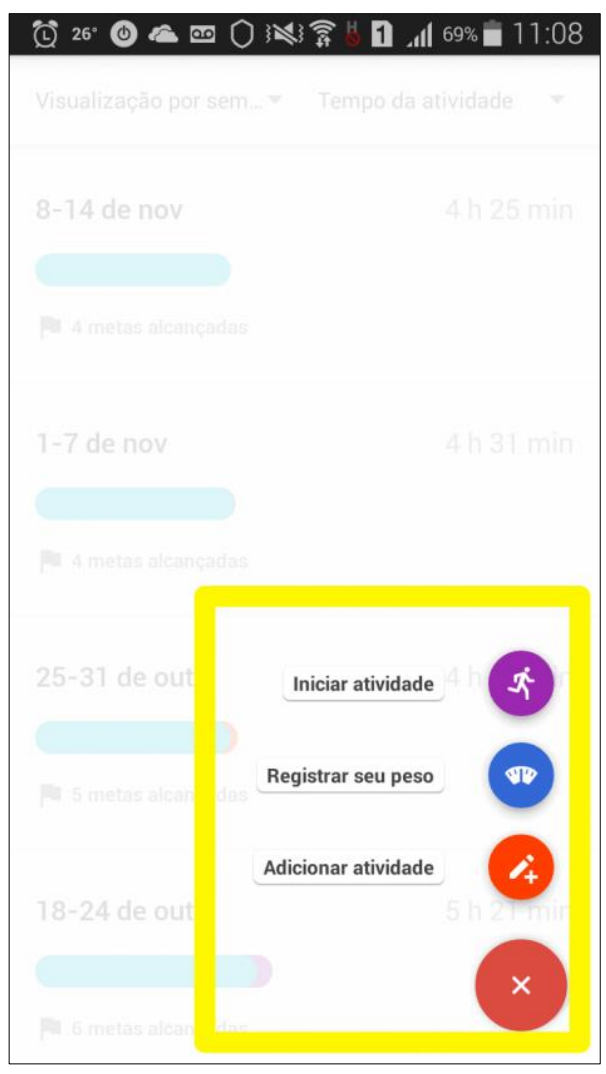

Figura 49: Captura de tela do aplicativo Google Fit, ilustrando um exemplo de botão de ação, destacado em amarelo
A respeito da palavra "Tipo", os

participantes a descreveram como

“classificação", "categorizar diferentes ícones

que são de uma mesma área, porém possuem características variadas" e "classifica (projeto, tarefa, atividade, evento) ", aproximando-se da real intenção do termo no ambiente, que é a de filtrar a exibição dos diferentes tipos de envio que o usuário pode fazer. Desta forma, os participantes sugeriram os termos "Filtro" e "Categoria" para tornar a ação mais clara.

Ainda sobre os tipos de envio, o termo "Nova postagem" foi descrito como "criação de um novo ícone para veicular uma notícia ou uma informação importante para o grupo". A descrição não associava a ação a um evento, ou a um arquivo, intenção original do botão, como ilustrado na Figura 48. O botão de "Nova Postagem" atualmente leva a uma tela na qual o usuário pode escolher qual o tipo de envio que deseja fazer ao mural do projeto, ou seja, fazer um aviso geral, iniciar um fórum, enviar um documento, definir uma tarefa ou alertar sobre um evento. Os participantes sugeriram o termo "novo +", possivelmente por influência do padrão de design de aplicativos do Google, que usa botões de ação flutuantes, normalmente contendo um símbolo de “+” dentro de um círculo, com o objetivo promover uma ação de criação por parte do usuário (Google, 2015), como ilustra a Figura 49.

Com relação ao termo "Anúncio", a maioria associou a palavra ao significado de publicidade. Duas pessoas associaram à real intenção do uso da palavra: uma informação importante a ser divulgada para todo o grupo. Neste caso, houve consenso de que a palavra que melhor representava este conceito seria "Aviso".

Já sobre o vocábulo "Tópico", este foi o que teve interpretação mais divergente da intenção inicial: os participantes descreveram o termo como um item, ou seja, uma divisão dentro de uma tarefa ou de um tema, resumindo uma informação. Porém, o 
significado da palavra para a equipe de criação do ambiente representava um dos tipos de conteúdo que o integrante do projeto poderia enviar, nesse caso em formato de texto, que pode ser comentado pelos colegas de equipe. Após conversar com os participantes da validação, debatendo entre termos como "Discussão", "Chat" e "Fórum", optou-se por utilizar a palavra "Fórum", que transmite melhor a ideia do conteúdo.

Sobre as funções de "Administrador" e "Coordenador", houve uma discussão mais longa que a dos outros termos, pois parte dos participantes da validação acreditava que o primeiro era hierarquicamente superior ao segundo e a outra parte pensava o contrário, justificando sua lógica por meio de suas próprias experiências em projetos e pelo uso de outros aplicativos com Whatsapp e Facebook. Foi explicado, então, que para o contexto da UnB, o coordenador de um projeto é aquele que assina a documentação junto à Fundação Universidade de Brasília, desta forma, tem papel superior ao de um administrador, que auxilia no gerenciamento do projeto. Após estas discussões, chegou-se ao consenso de que poderia ser usado tanto um termo quanto o outro; o que diferenciaria na hierarquia seria o sufixo "do projeto", para quem tem hierarquia superior (ex: "Coordenador do projeto" ou "Administrador do projeto") e o sufixo "do subgrupo/núcleo", para quem exercesse o papel de liderança dentro de uma etapa do projeto.

A dinâmica de validação dos termos foi de extrema importância para a melhoria da acessibilidade do aplicativo, pois os jargões internalizados dentro da equipe de desenvolvimento não são necessariamente termos utilizados ou compreendidos por outros grupos de desenvolvimento de projetos colaborativos. Observou-se que muitos dos termos, se isolados do contexto, geraram confusão quanto ao entendimento. $\mathrm{O}$ objetivo da dinâmica foi cumprido, pois houve a validação dos termos tanto fora quanto dentro do contexto do aplicativo, auxiliando no processo de melhoria da acessibilidade quanto à linguagem, contando com a colaboração dos participantes na proposição de novos termos que sejam mais compreensíveis.

Desta forma, a solução final desenvolvida contou com as alterações necessárias à adaptação ao contexto geral de desenvolvimento de projetos colaborativos e participativos, abrangendo mudanças na navegação, no layout, e na linguagem utilizada para melhor atender aos contextos complexos desses tipos de projeto, que envolvem estudantes e profissionais de diversas áreas do conhecimento, além de várias etapas com relações de interdependência e que, ainda assim, precisam ser devidamente registradas 
de forma a manter a gestão do conhecimento, mas de modo a facilitar a navegação e a busca do usuário às informações que ele precisar, no momento que desejar. A Figura 50 apresenta capturas de tela do aplicativo, disponível no endereço eletrônico $<$ http://tienmi.mobi>.

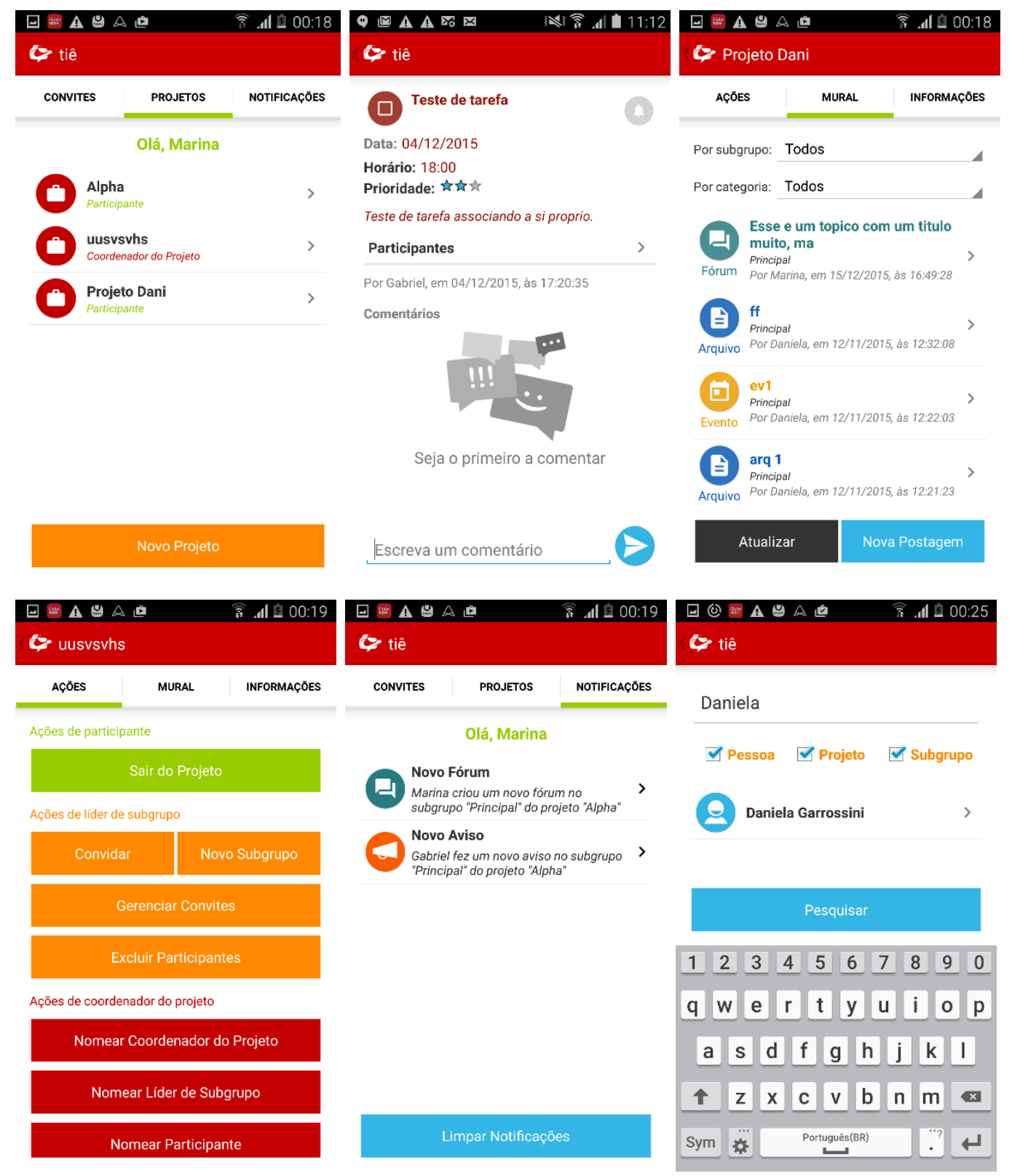

Figura 50: Capturas de tela da solução desenvolvida 


\section{Capítulo 4: Conclusões}

Esta dissertação utilizou-se de metodologias participativas e colaborativas para a sua construção, com vistas a atender, de forma inovadora, a uma lacuna na área de desenvolvimento de projetos, aliando as novas tecnologias da informação e da comunicação aos métodos e processos atuais de gestão de projetos, auxiliando equipes interdisciplinares a trabalhar colaborativamente e participativamente.

O ambiente digital concebido foi analisado quanto à capacidade de atender às necessidades dos requisitos levantados, cumprindo a todos e transpassando-os, pois não resultou em ser útil apenas ao ensino superior, como inicialmente proposto, mas a todas as situações que envolvam o desenvolvimento de projetos colaborativos, em qualquer setor da sociedade, permitindo a gestão de projetos com base nos princípios da facilitação da recuperação das informações, da manutenção do histórico de projetos, do auxílio na gestão do conhecimento e da gestão colaborativa por meio do aprendizado utilizando dispositivos móveis, o m-learning.

Ao se realizar uma análise contextual e metodológica dos contextos e as necessidades de desenvolvimento de projetos colaborativos para ensino de graduação, tanto dos que têm o Project-Based Learning como base quanto dos que não têm, além de identificar e analisar as condições existentes para o gerenciamento de informação e comunicação em projetos colaborativos, percebeu-se, por meio de entrevistas, aplicação de questionários, observação dos alunos e de experiências empíricas que as falhas na comunicação e a falta de visualização do projeto em sua totalidade são problemas recorrentes, inclusive no desenvolvimento da própria solução projetada ao longo desta pesquisa para melhor atender aos requisitos levantados para um espaço virtual que auxilie o desenvolvimento de projetos colaborativos.

Após analisar os ambientes com base nestes requisitos, foi concebido o projeto de um ambiente digital que permita a gestão colaborativa de projetos, com base nos princípios de facilitar a recuperação das informações, manter histórico do projeto, auxiliar na gestão do conhecimento e permitir a gestão colaborativa por meio do $\mathrm{m}$ learning. Porém, visto que a gama de usuários pode ser tão ampla, ultrapassando a área acadêmica, verificou-se a necessidade de verificar o ambiente quanto à sua acessibilidade, pois a equipe de desenvolvimento do aplicativo não conseguiu realizar a construção do espaço em constante validação com os usuários, resultando em uma 
linguagem composta por termos específicos da equipe, gerando dúvidas quanto à compreensão destes vocábulos por outros grupos que desenvolvam projetos colaborativos. A validação foi realizada com sucesso, resultando em melhorias na compreensão da linguagem pelos usuários, confirmando que o contexto de cada pessoa, em cada área, interagindo com diferentes pessoas, que têm conhecimentos, influencia a maneira de se perceber tanto os termos utilizados quanto a navegação no ambiente.

O Tiê está divulgado no endereço <http://www.tienmi.mobi $>$, onde consta o histórico resumido do desenvolvimento e posteriormente será disponibilizado o download gratuito do aplicativo para uso.

De forma a complementar este estudo, ele ainda pode ser beneficiado de validações posteriores, que não puderam ser realizadas neste estudo, tais como avaliações de interface e da navegação do ambiente, além de se observar e validar o uso desta solução desenvolvida em contexto tanto do desenvolvimento de projetos no ambiente acadêmico, quanto em contexto profissional, com o objetivo de demonstrar que as possibilidades de uso do Tiê, a solução desenvolvida, ultrapassam as barreiras da sala de aula e adquirem novos usos em situações além do PBL. Os roteiros propostos para essas avaliações encontram-se disponíveis nos anexos VII e VIII. 


\section{Referências}

AGNI, E. Planejamento de um wireframe orientado para aplicativos. In: UX.BLOG. 2011. <http://www.uxdesign.blog.br/user-experience/review-da-palestraplanejamento-de-um-wireframe-orientado-para-aplicativos-no-intercon2011/>. Acesso em 12 de abril de 2015.

ANTÓN M. The Discourse of a Learner-Centered Classroom: Sociocultural Perspectives on Teacher-Learner Interaction in the Second-Language Classroom. The Modern Language Journal. v. 83, Issue 3,303-318, 1999.

BASECAMP. 2015. Disponível em: http://www.basecamp.com

BIE. What is Project Based Learning (PBL)?. In: Buck Institute for Education. 2015. Disponível em: <http://bie.org/about/what_pbl>. Acesso em 16 de março de 2015. . Why Project Based Learning (PBL)?. In: Buck Institute for Education. 201. Disponível em: <http://bie.org/about/why_pbl>. Acesso em 16 de março de 2015.

CARROL, J.M. Designing interaction: psychology at the human-computer interface. Cambridge: Cambridge University Press. 1991.

CARSON, R. L. How to communicate in a \#nomanager company. 2013. Disponível em: <http://ryancarson.com/post/63593803482/how-to-communicate-in-a-nomanagercompany $\geq$. Acesso em 22 de setembro de 2014.

How to set priorities, create budgets and do project management in a \#nomanager company. 2013. Disponível em:

$<$ http://ryancarson.com/post/61606695537/how-to-set-priorities-create-budgetsand-do-project $\geq$. Acesso em 24 de setembro de 2014.

DEEGAN, R. \& ROTHWELL, P. A Classification of M-Learning Applications from a Usability Perspective. Journal of the Research Center for Educational Technology, v.6, 16-27. 2010.

GARRETT, J. J. The elements of user experience: User-centered design for the Web and beyond. Berkeley, CA: New Riders. 2011.

HARASIM, L. et al. Redes de aprendizagem: Um guia para ensino e aprendizagem online. São Paulo: Editora Senac. 2005. 
GARROSSINI, D. F. et al. O uso das Tecnologias da Informação e Comunicação para o desenvolvimento de trabalho em equipe à distância a partir de ambientes colaborativos desenvolvidos para dispositivos móveis. Em: Fourth International Symposium on Project Approaches in Engineering Education - PAEE 2012, 2012, São Paulo. Proceedings of the Fourth International Symposium on Project Approaches in Engineering Education (PAEE'2012). Guimarães, PT: Research Centre in Education - CIEd, University of Minho and Department of Production and Systems, 2012. v. 1. p. 339-346.

GARROSSINI, D.F. \& KALUME, A. C. Dispositivos móveis e trabalho em equipe a partir de ambientes colaborativos: um estudo sobre o desenvolvimento do aplicativo Tiê. Em: Revista de Design, Tecnologia e Sociedade. v.1, n.1, Brasília: Programa de Pós-Graduação em Design da Universidade de Brasília. 2014, pp. 69-87.

GOOGLE. Buttons: Floating Action Button in Material Design Guidelines (site).

Disponível em: <https://www.google.com/design/spec/components/buttons-floatingaction-button.html>. Acesso em 20 de outubro de 2015.

JACOBSON, R. (ed.). Information design. Cambridge: The MIT Press. 2000.

KUMAR, D. \& TURNER, J. Education for the 21st Century: Impact of ICT and Digital Resources. New York: Springer. 2006.

MARKHAM, T.Project Based Learning: design and coaching guide. HeartIQ Press, California. 2012.

MORIN, Edgar. Educação e complexidade: os sete saberes e outros ensaios. 3. ed. São Paulo: Cortez, 2013. . Introdução ao pensamento complexo. Porto Alegre: Sulina, 2005.

NONAKA, I; TAKEUCHI, H. Gestão do Conhecimento. Porto Alegre: Editora Bookman, 2008.

PALANGANA, I. C. Desenvolvimento e aprendizagem em Piaget e Vygotsky: a relevância do social. São Paulo: Plexus, 1994.

SACCOL, A, SCHLEMMER, E, BARBOSA, J. m-Learning e u-Learning: novas perspectivas da aprendizagem móvel e ubíqua. São Paulo: Pearson Prentice Hall, 2011. 
SANTA ROSA, J.G; MORAES, A. Avaliação e Projeto no Design de Interfaces. Rio de Janeiro: 2AB, 2012.

TRELLO. Disponível em: <https://trello.com>. Acesso em 16 de março de 2015.

VIANA, D. M. et al. Uma Experiência de Aprendizagem Colaborativa Interdisciplinar no Desenvolvimento de um Veículo Elétrico na Universidade de Brasília. In: Third International Symposium on Project Approaches in Engineering Education (PAEE 2011): Aligning Engineering Education with Engineering Challenges, 2011, Lisboa (PT). Proceedings of the Third International Symposium on Project Approaches in Engineering Education (PAEE 2011): Aligning Engineering Education with Engineering Challenges. Guimarães - Portugal: Research Centre in Education (CiEd), University of Minho, 2011. v. 1. p. 73-79.

VARGAS, R. V. Gerenciamento de projetos: Estabelecendo diferenciais competitivos. 6 ed. Rio de Janeiro: Brasport, 2002.

VYGOTSKY, L. S. (2007). A formação social da mente. São Paulo: Martins Fontes 
Anexos 


\section{Anexo I: Questionário sobre o perfil dos alunos do Projeto Integrador com relação ao uso de dispositivos móveis}

1 Em qual curso você está matriculado na Universidade de Brasília?

2 Qual a sua participação no Projeto Ciclar?

○ Equipe

- Professor Orientador

- Coordenador do Projeto

- Integrante da equipe de Elétrica, Automação e Controle

○ Integrante da equipe de Estrutura, Mecânica e Componentes

- Integrante da equipe de Design

○ Coordenador da equipe de Elétrica, Automação e Controle

- Coordenador da equipe de Estrutura, Mecânica e Componentes

- Coordenador da equipe de Design

3 Você utiliza um dispositivo móvel, de que tipo? (É possível marcar mais de uma opção)
- Celular
○ Smartphone
- Tablet
○ PDA
○ Outros (PSP, Nintendo DS,...)
○ Nenhum

4 Qual a marca e modelo do dispositivo móvel que você mais utiliza?

5 Qual o sistema operacional do dispositivo que você mais utiliza?
○ Android
- Windows Phone
○ Windows Mobile
○ iOS
○ Blackberry OS
- Outro

6 Você tem um plano de dados para esse dispositivo, de que tipo?
○ Ilimitado
○ Limitado
○ Pré-pago
○ Não tenho plano de dados 
7 Quanto à forma de navegação desse dispositivo, como você navega e acessa menus? (É possível marcar mais de uma opção)
○ Teclado / Teclas
○ Touch screen
○ Scroll wheel
○ Outro

8 Qual forma de comunicação você utiliza com mais frequência? (É possível marcar mais de uma opção)
○ SMS
○ MMS
○ Email
- Chamada de $\mathrm{Voz}$
○ Video conferência
○ Outro

9 Você utiliza algum aplicativo para comunicação, qual? (É possível marcar mais de uma opção)
○ Whatsapp
○ Skype
○ Voxer
○ Tango
$\circ$ iMessenger
○ eBuddy
○ netTALK.com
○ Viber
○ BlackBerry Messenger
○ Outro

10 Quais as principais funções desse dispositivo no seu dia-a-dia? (É possível marcar mais de uma opção)
○ Fazer ligações
- Navegar na internet
○ Ler emails
- Receber e enviar mensagens de texto
- Tirar fotos
- Escutar música
○ Jogar 
- Receber e enviar aquivos como PDFs, planilhas, textos e imagens

$\circ$ Outro

11 No seu dispositivo móvel, você utiliza aplicativos para receber, abrir e enviar arquivos (PDFs, planilhas, textos, imagens), quais?
○ Não compartilho
- Sim, somente por email
- Sim, por icloud
- Sim, pelo dropbox
○ Sim, pelo Google Docs
○ Outro

12 Qual a capacidade de armazenamento do seu dispositivo?
○ até $64 \mathrm{MB}$
até $128 \mathrm{MB}$
○ até $256 \mathrm{MB}$
○ até $512 \mathrm{MB}$
○ até $1 \mathrm{~GB}$
○ até $2 \mathrm{~GB}$
○ até $4 \mathrm{~GB}$
○ até $8 \mathrm{~GB}$
○ até $16 \mathrm{~GB}$
○ até $32 \mathrm{~GB}$
- mais que $32 \mathrm{~GB}$

13 Qual a autonomia bateria do seu dispositivo?
○ até 2 horas
- até 4 horas
○ até 6 horas
- até 8 horas
○ até 10 horas
$\circ$ até 12 horas
$\bigcirc$ até 14 horas
○ até 16 horas
$\circ$ até 18 horas
○ até 20 horas
- mais 20 horas 


\section{Anexo II: Respostas ao questionário sobre o perfil dos alunos do Projeto Integrador com relação ao uso de dispositivos móveis}

Este questionário foi elaborado e aplicado no ano de 2012 aos estudantes do Projeto Integrador, resultando em 16 respostas compiladas a seguir.

\section{1 - Em qual curso você está matriculado na Universidade de Brasília?}

\begin{tabular}{lll}
\hline Curso & & \\
\hline Desenho Industrial & 2 & $13 \%$ \\
Engenharia de Computação & 1 & $6 \%$ \\
Engenharia Elétrica & 3 & $19 \%$ \\
Engenharia Eletrônica - Campi Gama & 1 & $6 \%$ \\
Engenharia Mecânica & 5 & $31 \%$ \\
Engenharia Mecatrônica & 4 & $\mathbf{2 5 \%}$ \\
\hline Total & $\mathbf{1 6}$ & $\mathbf{1 0 0} \%$ \\
\hline
\end{tabular}

2 - Qual a sua participação no Projeto Ciclar?

\begin{tabular}{lll}
\hline Equipe & & \\
\hline Professor Orientador & 0 & $0 \%$ \\
Coordenador do Projeto & 0 & $0 \%$ \\
\hline Integrante da equipe de Elétrica, Automação e Controle & 8 & $50 \%$ \\
\hline Integrante da equipe de Estrutura, Mecânica e Componentes & 5 & $31 \%$ \\
\hline Integrante da equipe de Design & 1 & $6 \%$ \\
Coordenador da equipe de Elétrica, Automação e Controle & 1 & $6 \%$ \\
Coordenador da equipe de Estrutura, Mecânica e Componentes & 0 & $0 \%$ \\
Coordenador da equipe de Design & 1 & $6 \%$ \\
\hline
\end{tabular}

3 - Você utiliza um dispositivo móvel, de que tipo?

\begin{tabular}{lll}
\hline Celular & 6 & $38 \%$ \\
\hline Smartphone & 13 & $81 \%$ \\
Tablet & 2 & $13 \%$ \\
PDA & 1 & $6 \%$ \\
Outros (PSP, Nitendo DS,...) & 3 & $19 \%$ \\
Nenhum & 0 & $0 \%$ \\
\hline Total & $\mathbf{2 5}$ & \\
\hline
\end{tabular}

As pessoas contavam com a possibilidade de marcar mais de uma caixa de seleção, então a soma das porcentagens pode ultrapassar $100 \%$.

4 - Qual a marca e modelo do dispositivo móvel que você mais utiliza?

\begin{tabular}{|c|c|}
\hline 1 & Apple -iPhone 3GS \\
\hline 2 & Apple -iPhone 3GS \\
\hline 3 & Samsung \\
\hline 4 & Apple - iPhone 4 \\
\hline 5 & Apple - iPad 1 \\
\hline
\end{tabular}




\begin{tabular}{ll}
$\mathbf{6}$ & Blackberry \\
7 & Samsung - Galaxy S II \\
$\mathbf{8}$ & Apple - iPhone 4S \\
$\mathbf{9}$ & Motorola \\
$\mathbf{1 0}$ & Sony Ericcson - x10 mini \\
$\mathbf{1 1}$ & Nokia \\
\hline 12 & Apple - iPhone 4 \\
\hline 13 & Sansumg - Galaxy S \\
\hline 14 & Apple - iPhone 4 \\
\hline 15 & Nokia - Xperia 3120C \\
\hline
\end{tabular}

5 - Qual o sistema operacional do dispositivo que você mais utiliza?

\begin{tabular}{lll}
\hline Android & $\mathbf{5}$ & $\mathbf{3 1 \%}$ \\
\hline Windows Phone & 0 & $0 \%$ \\
Windows Mobile & 1 & $6 \%$ \\
iOS & 5 & $31 \%$ \\
\hline Blackberry OS & 1 & $6 \%$ \\
\hline Outro & 4 & $25 \%$ \\
\hline
\end{tabular}

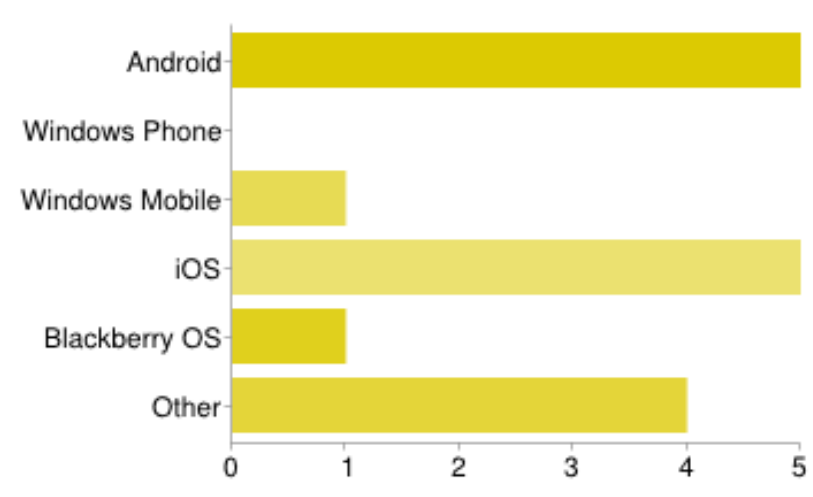

6 - Você tem um plano de dados para esse dispositivo, de que tipo?

\begin{tabular}{lll}
\hline Ilimitado & $\mathbf{4}$ & $\mathbf{2 5} \%$ \\
\hline Limitado & 5 & $31 \%$ \\
Pré-pago & 3 & $19 \%$ \\
Não tenho plano de dados & 4 & $25 \%$ \\
\hline Total & 16 & $100 \%$ \\
\hline
\end{tabular}

7 - Quanto à forma de navegação desse dispositivo, como você navega e acessa menus?

\begin{tabular}{lll}
\hline Teclado/ Teclas & $\mathbf{4}$ & $\mathbf{2 7 \%}$ \\
\hline Touch screen & 11 & $\mathbf{7 3} \%$ \\
Scroll wheel & 1 & $\mathbf{7} \%$ \\
Outro & 1 & $\mathbf{7} \%$ \\
\hline
\end{tabular}

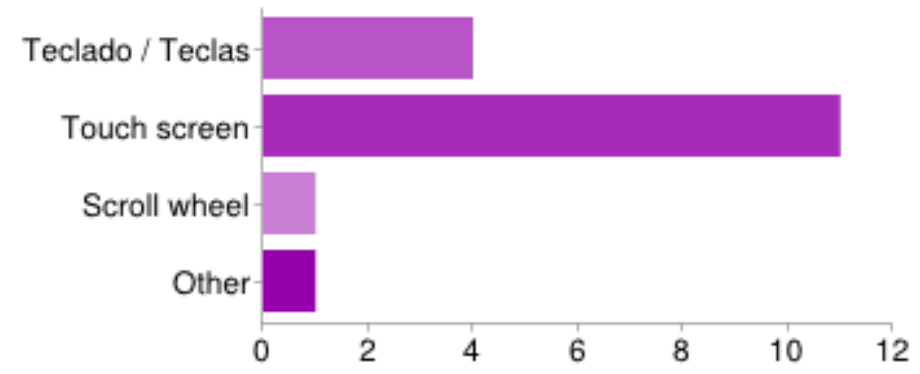

As pessoas contavam com a possibilidade de marcar mais de uma caixa de seleção, então a soma das porcentagens pode ultrapassar $100 \%$. 
8 - Qual forma de comunicação você utiliza com mais frequência?

\begin{tabular}{lll}
\hline SMS & $\mathbf{1 1}$ & $\mathbf{6 9} \%$ \\
\hline MMS & 1 & $6 \%$ \\
Email & 10 & $63 \%$ \\
Chamada de Voz & 5 & $31 \%$ \\
Video conferência & 1 & $6 \%$ \\
Outro & 0 & $0 \%$ \\
\hline
\end{tabular}

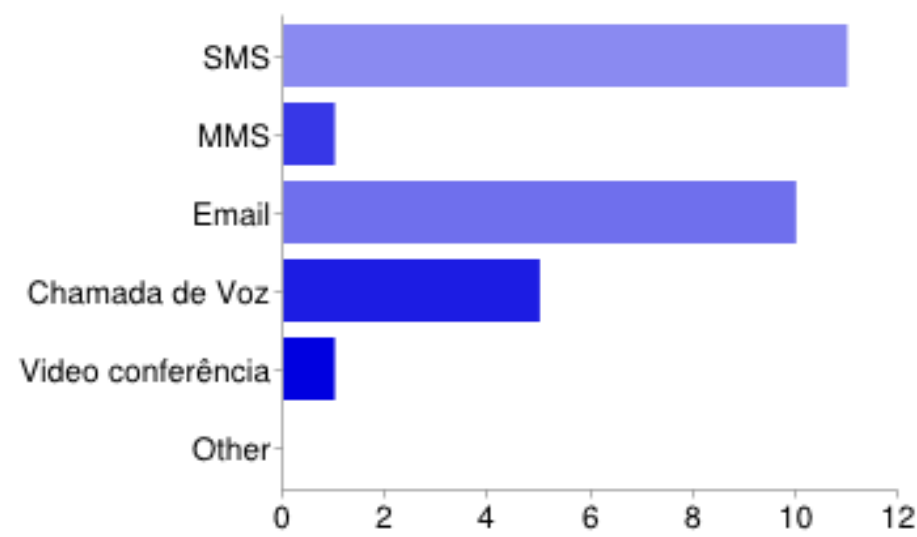

As pessoas contavam com a possibilidade de marcar mais de uma caixa de seleção, então a soma das porcentagens pode ultrapassar $100 \%$.

9 - Você utiliza algum aplicativo para comunicação, qual?

\begin{tabular}{lll}
\hline Whatsapp & $\mathbf{7}$ & $\mathbf{5 4 \%}$ \\
\hline Skype & 6 & $46 \%$ \\
Voxer & 0 & $0 \%$ \\
Tango & 1 & $8 \%$ \\
iMessenger & 4 & $31 \%$ \\
eBuddy & 1 & $8 \%$ \\
netTALK.com & 0 & $0 \%$ \\
Viber & 4 & $31 \%$ \\
\hline BlackBerry Messenger & 0 & $0 \%$ \\
Outro & 1 & $8 \%$ \\
\hline
\end{tabular}

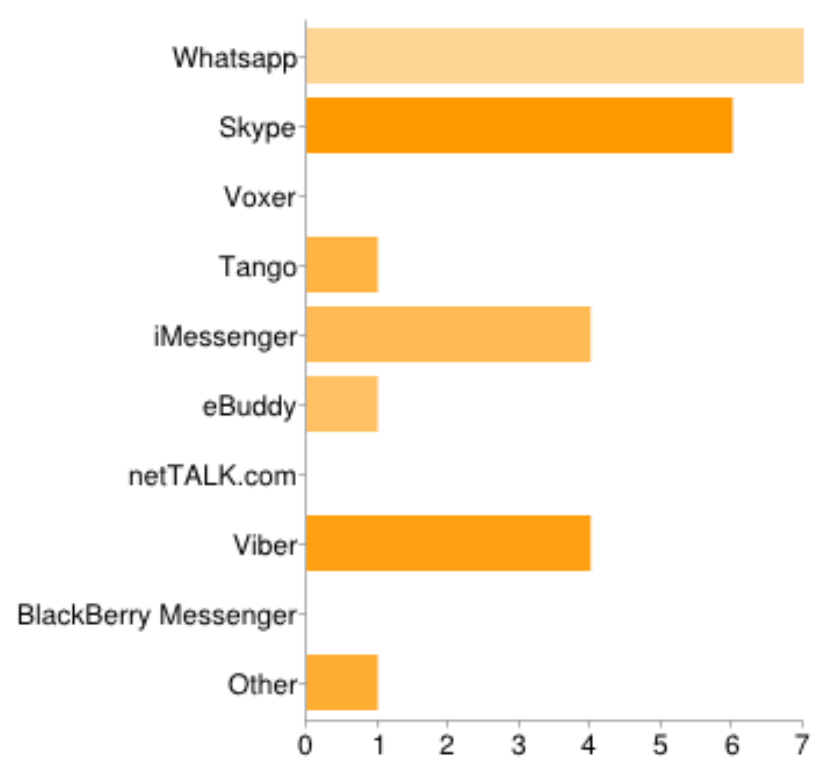

As pessoas contavam com a possibilidade de marcar mais de uma caixa de seleção, então a soma das porcentagens pode ultrapassar $100 \%$.

10 - Quais as principais funções desse dispositivo no seu dia-a-dia?

\begin{tabular}{lll}
\hline Fazer ligações & $\mathbf{1 4}$ & $\mathbf{8 8 \%}$ \\
\hline Navegar na internet & 8 & $50 \%$ \\
Ler emails & 9 & $56 \%$ \\
Receber e enviar mensagens de texto & 12 & $75 \%$ \\
\hline Tirar fotos & 8 & $50 \%$ \\
Escutar música & 7 & $44 \%$ \\
\hline Jogar & 5 & $31 \%$ \\
Receber e enviar aquivos como PDFs, planilhas, textos e imagens & 5 & $31 \%$ \\
\hline Outro & 0 & $0 \%$ \\
\hline
\end{tabular}

As pessoas contavam com a possibilidade de marcar mais de uma caixa de seleção, então a soma das porcentagens pode ultrapassar $100 \%$. 
11 - No seu dispositivo móvel, você utiliza aplicativos para receber, abrir e enviar arquivos (PDFs, planilhas, textos, imagens), quais?

\begin{tabular}{lll}
\hline Não compartilho & 5 & $31 \%$ \\
\hline $\begin{array}{l}\text { Sim, somente por } \\
\text { email }\end{array}$ & 5 & $31 \%$ \\
\end{tabular}

Sim, por icloud

Sim, pelo dropbox

Sim, pelo Google

Docs

\section{Outro}

$0 \%$

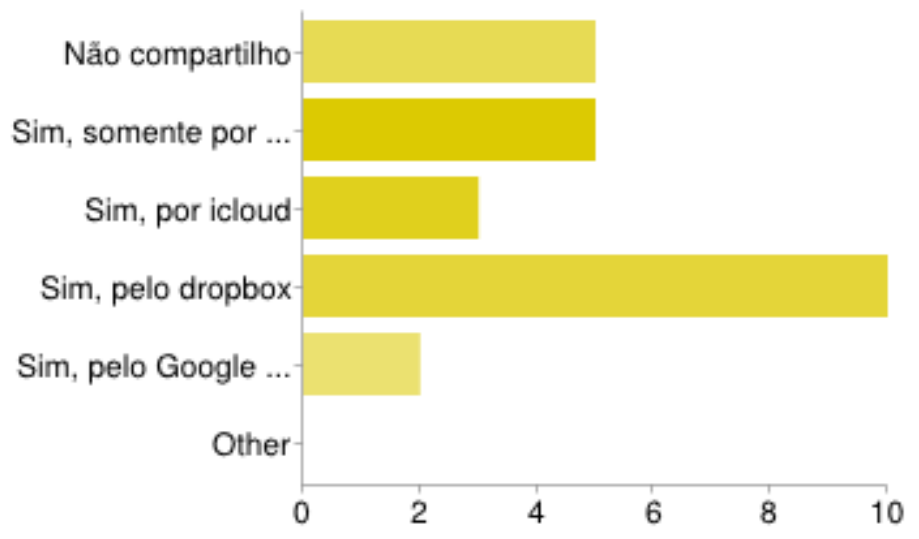

12 - Qual a capacidade de armazenamento do seu dispositivo?

\begin{tabular}{lll} 
& & \\
\hline até $64 \mathrm{MB}$ & 0 & $0 \%$ \\
\hline até $128 \mathrm{MB}$ & 0 & $0 \%$ \\
\hline até $256 \mathrm{MB}$ & 0 & $0 \%$ \\
\hline até $512 \mathrm{MB}$ & 0 & $0 \%$ \\
\hline até $1 \mathrm{~GB}$ & 1 & $6 \%$ \\
\hline até $2 \mathrm{~GB}$ & 3 & $19 \%$ \\
\hline até $4 \mathrm{~GB}$ & 2 & $13 \%$ \\
\hline até $8 \mathrm{~GB}$ & 4 & $25 \%$ \\
\hline até $16 \mathrm{~GB}$ & 3 & $19 \%$ \\
\hline até $32 \mathrm{~GB}$ & 1 & $6 \%$ \\
\hline mais que & 0 & $0 \%$ \\
\hline 32 GB & &
\end{tabular}

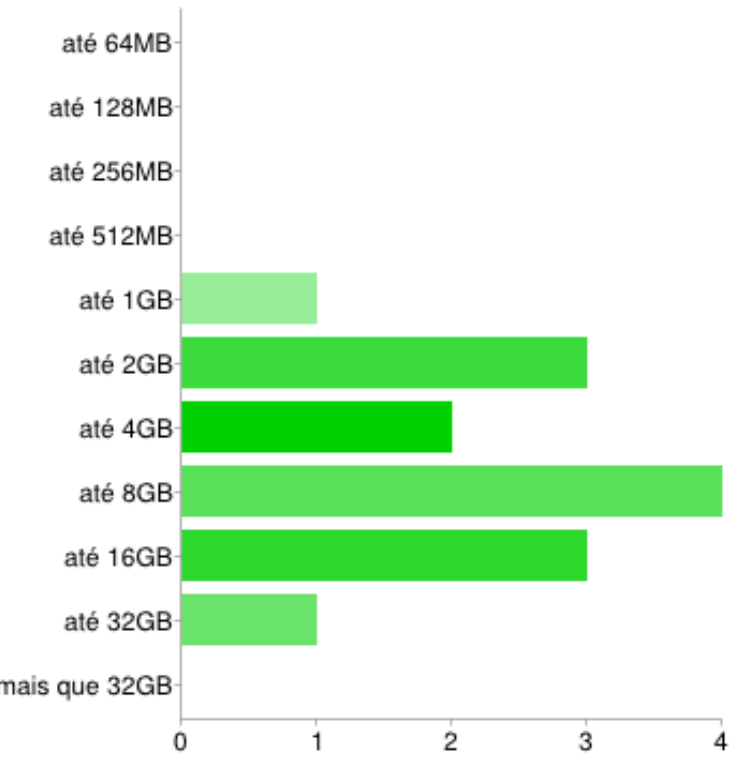


13 - Qual a autonomia bateria do seu dispositivo?

\begin{tabular}{lll}
\hline até $\mathbf{2}$ horas & $\mathbf{0}$ & $\mathbf{0} \%$ \\
\hline até $\mathbf{4}$ horas & 0 & $0 \%$ \\
\hline até $\mathbf{6}$ horas & 2 & $13 \%$ \\
\hline até $\mathbf{8}$ horas & 1 & $6 \%$ \\
\hline até $\mathbf{1 0}$ horas & 2 & $13 \%$ \\
\hline até $\mathbf{1 2}$ horas & 3 & $19 \%$ \\
\hline até $\mathbf{1 4}$ horas & 0 & $0 \%$ \\
\hline até $\mathbf{1 6}$ horas & 0 & $0 \%$ \\
\hline até $\mathbf{1 8}$ horas & 3 & $19 \%$ \\
\hline até $\mathbf{2 0}$ horas & 1 & $6 \%$ \\
mais $\mathbf{2 0}$ horas & 4 & $\mathbf{2 5} \%$ \\
\hline
\end{tabular}

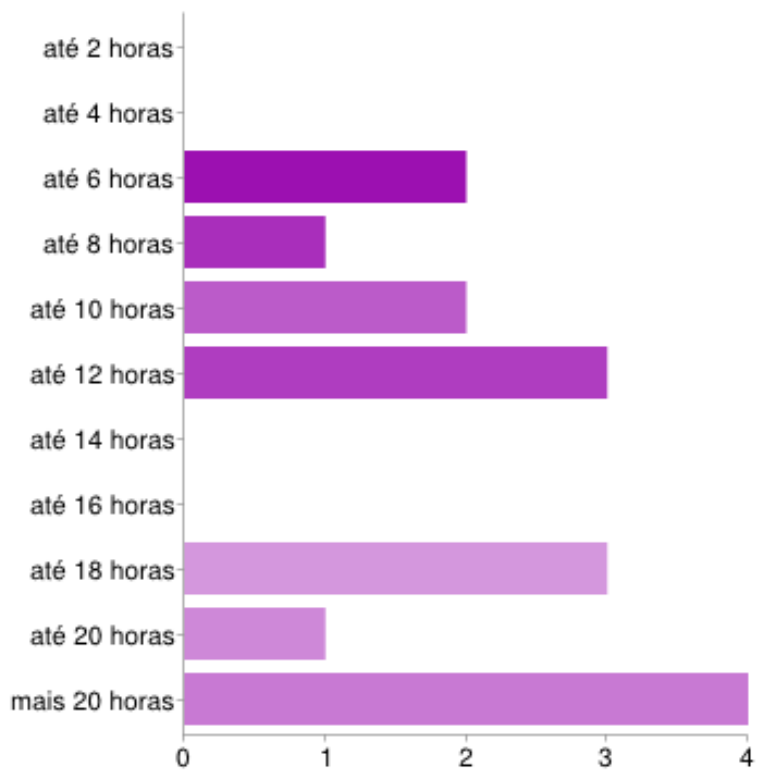


Anexo III: Questionário sobre a percepção individual dos alunos do Projeto Integrador quanto ao desenvolvimento do projeto e o relacionamento com a equipe

O objetivo deste questionário é coletar informações dos estudantes sobre os aspectos do trabalho envolvendo sua equipe de trabalho.

Responda às questões marcando a resposta que melhor identifique sua opinião.

\section{Subprojeto}

\section{Quantos membros pertencem à equipe?}

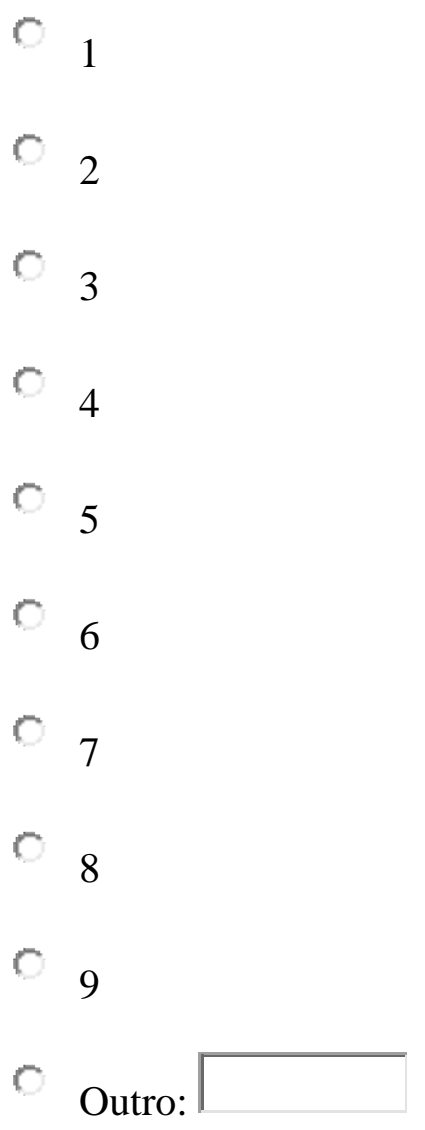

2.1 Como você avalia a participação dos membros da equipe de forma geral?

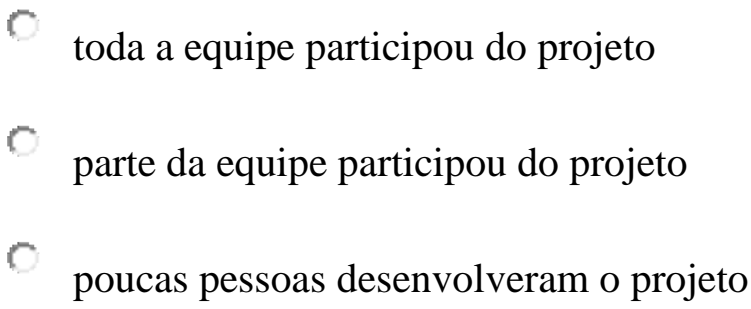




\section{Em relação aos membros da equipe, responda:}

3.1 Houve a capacidade dos membros para apresentar e desenvolver ideias, aprimorar técnicas e métodos de trabalho?

não apresentaram capacidade para sugerir novas alternativas
demonstra alguma dificuldade em apresentar ideias
todos tiveram facilidade em apresentar novos recursos para aprimorar técnicas e métodos de trabalho

3.2 Houve disposição da equipe para agir e solucionar problemas recorrendo a outras pessoas?

ficaram sem ação quando havia dúvidas ou problemas de trabalho

procuraram agir frente a maioria das situações ocorridas

agiram prontamente frente a todas as dúvidas e problemas sugeridos

3.3 Houve organização das tarefas e materiais, documentos e outros que utilizaram para realização de seu trabalho?

todos foram muito organizados quanto ao controle e ao cuidado nas atividades

não foram organizados, perderam-se frequentemente na execução de seu trabalho

não chegaram a se perder em seu trabalho, mas apresentaram dificuldades em desenvolver meios de organizar suas atividades

3.4 Em relação à frequência no trabalho, como também às faltas justificadas:

Raramente faltaram. Quando isto ocorreu foi por motivo justo e autorizado.

Houveram faltas ocasionais, sendo que algumas não foram justificadas.

Faltaram frequentemente sem justificativas. 


\section{Responda de maneira geral como avalia os colegas envolvidos no projeto}

4.1

apresentou acentuada dificuldade em se relacionar com as pessoas

necessitou orientação constante para melhorar seu relacionamento

apresentou facilidade em estabelecer contatos

desenvolveu bem suas atividades

colaborou constantemente na resolução de problemas

Nome:

4.2

apresentou acentuada dificuldade em se relacionar com as pessoas

necessitou orientação constante para melhorar seu relacionamento

apresentou facilidade em estabelecer contatos

desenvolveu bem suas atividades

colaborou constantemente na resolução de problemas

Г Nome:

4.3

apresentou acentuada dificuldade em se relacionar com as pessoas

necessitou orientação constante para melhorar seu relacionamento

apresentou facilidade em estabelecer contatos

desenvolveu bem suas atividades

colaborou constantemente na resolução de problemas

$\Gamma \quad$ Nome: 
apresentou acentuada dificuldade em se relacionar com as pessoas

necessitou orientação constante para melhorar seu relacionamento

apresentou facilidade em estabelecer contatos

desenvolveu bem suas atividades

colaborou constantemente na resolução de problemas

Г Nome:

4.5

apresentou acentuada dificuldade em se relacionar com as pessoas

necessitou orientação constante para melhorar seu relacionamento

apresentou facilidade em estabelecer contatos

$\ulcorner$ desenvolveu bem suas atividades

$\Gamma$ colaborou constantemente na resolução de problemas

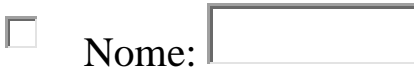

4.6

apresentou acentuada dificuldade em se relacionar com as pessoas

necessitou orientação constante para melhorar seu relacionamento

apresentou facilidade em estabelecer contatos

desenvolveu bem suas atividades

colaborou constantemente na resolução de problemas

Гome: 
apresentou acentuada dificuldade em se relacionar com as pessoas

$\Gamma$ necessitou orientação constante para melhorar seu relacionamento

$\Gamma$ apresentou facilidade em estabelecer contatos

$\Gamma$ desenvolveu bem suas atividades

$\Gamma$ colaborou constantemente na resolução de problemas

Г Other: 
Anexo IV: Respostas ao questionário sobre a percepção individual dos alunos do Projeto Integrador quanto ao desenvolvimento do projeto e o relacionamento com a equipe

\section{Subprojeto}

\begin{tabular}{|l|}
\hline Estrutura \\
\hline Carro Elétrico - Chassi/ Carroceria/ Freios \\
\hline Freios - Materiais (Chassi - Carroceria) \\
\hline Controle e Automação \\
\hline Motor e baterias \\
\hline Equipe de Elétrica \\
\hline Parte elétrica (baterias e motor) \\
\hline Materiais - Chassi e Carroceria \\
\hline Freios \\
\hline Transmissão \\
\hline Chassi e Carroceria \\
\hline Chassi (materiais 2) -> Transmissão \\
\hline Freio \\
\hline
\end{tabular}

2. Quantos membros pertencem à equipe?

\begin{tabular}{|r|}
\hline 7 \\
\hline 4 \\
\hline 3 \\
\hline 5 \\
\hline 5 \\
\hline 5 \\
\hline 7 \\
\hline 7 \\
\hline 7 \\
\hline 4 \\
\hline 5 \\
\hline 4 \\
\hline
\end{tabular}




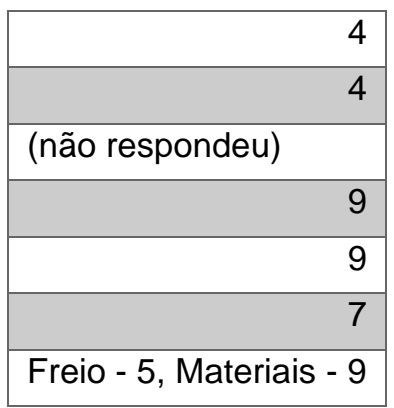

2.1 Como você avalia a participação dos membros da equipe de forma geral?

\begin{tabular}{|l|l|l|}
\hline $\begin{array}{l}\text { toda a equipe participou } \\
\text { do projeto }\end{array}$ & 12 & $63.2 \%$ \\
\hline $\begin{array}{l}\text { parte da equipe } \\
\text { participou do projeto }\end{array}$ & 4 & $21.1 \%$ \\
\hline $\begin{array}{l}\text { poucas pessoas } \\
\text { desenvolveram o projeto }\end{array}$ & 3 & $15.8 \%$ \\
\hline
\end{tabular}

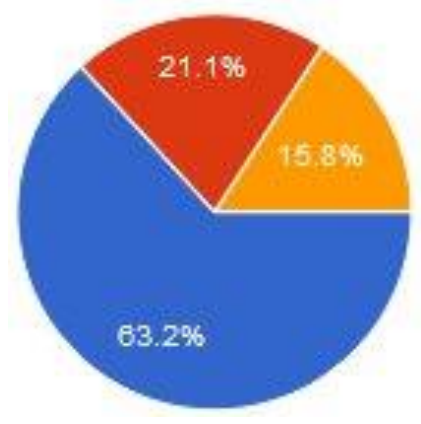

\section{Em relação aos membros da equipe, responda:}

3.1 Houve a capacidade dos membros para apresentar e desenvolver ideias, aprimorar técnicas e métodos de trabalho?

\begin{tabular}{|l|l|l|}
\hline $\begin{array}{l}\text { não apresentaram capacidade para } \\
\text { sugerir novas alternativas }\end{array}$ & 0 & $0 \%$ \\
\hline $\begin{array}{l}\text { demonstra alguma dificuldade em } \\
\text { apresentar ideias }\end{array}$ & 11 & $57.9 \%$ \\
\hline $\begin{array}{l}\text { todos tiveram facilidade em apresentar } \\
\text { novos recursos para aprimorar } \\
\text { técnicas e métodos de trabalho }\end{array}$ & 8 & $42.1 \%$ \\
\hline
\end{tabular}

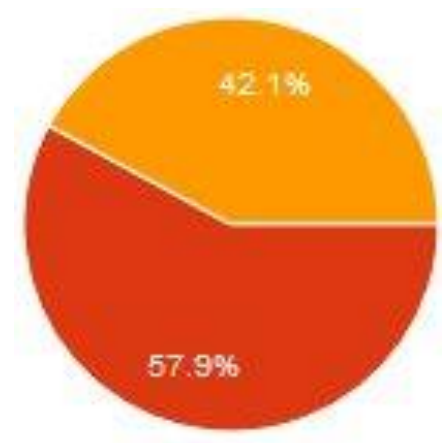

3.2 Houve disposição da equipe para agir e solucionar problemas recorrendo a outras pessoas?

\begin{tabular}{|l|l|l|}
\hline $\begin{array}{l}\text { ficaram sem ação quando havia } \\
\text { dúvidas ou problemas de trabalho }\end{array}$ & 2 & $10.5 \%$ \\
\hline $\begin{array}{l}\text { procuraram agir frente a maioria } \\
\text { das situações ocorridas }\end{array}$ & 16 & $84.2 \%$ \\
\hline $\begin{array}{l}\text { agiram prontamente frente a todas } \\
\text { as dúvidas e problemas sugeridos }\end{array}$ & 1 & $5.3 \%$ \\
\hline
\end{tabular}

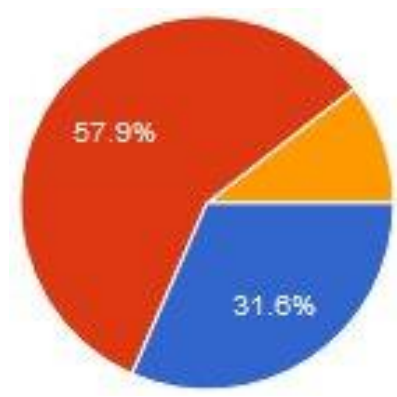


3.3 Houve organização das tarefas e materiais, documentos e outros que utilizaram para realização de seu trabalho?

\begin{tabular}{|l|l|l|}
\hline $\begin{array}{l}\text { todos foram muito organizados } \\
\text { quanto ao controle e ao cuidado } \\
\text { nas atividades }\end{array}$ & 7 & $36.8 \%$ \\
\hline $\begin{array}{l}\text { não foram organizados, } \\
\text { perderam-se frequentemente na } \\
\text { execução de seu trabalho }\end{array}$ & 2 & $10.5 \%$ \\
\hline $\begin{array}{l}\text { não chegaram a se perder em seu } \\
\text { trabalho, mas apresentaram } \\
\text { dificuldades em desenvolver } \\
\text { meios de organizar suas } \\
\text { atividades }\end{array}$ & 10 & $52.6 \%$ \\
\hline
\end{tabular}

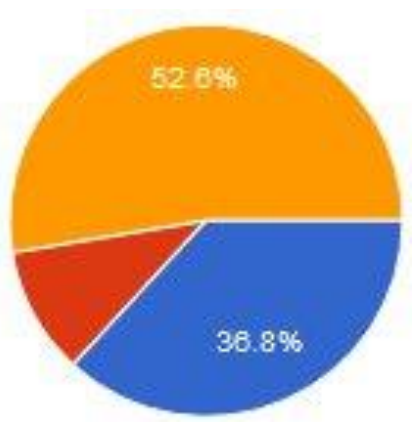

3.4 Em relação à frequência no trabalho, como também às faltas justificadas:

\begin{tabular}{|l|l|l|}
\hline $\begin{array}{l}\text { Raramente faltaram. } \\
\text { Quando isto ocorreu foi por } \\
\text { motivo justo e autorizado. }\end{array}$ & 6 & $31.6 \%$ \\
\hline $\begin{array}{l}\text { Houveram faltas ocasionais, } \\
\text { sendo que algumas não } \\
\text { foram justificadas. }\end{array}$ & 11 & $57.9 \%$ \\
\hline $\begin{array}{l}\text { Faltaram frequentemente } \\
\text { sem justificativas. }\end{array}$ & 2 & $10.5 \%$ \\
\hline
\end{tabular}

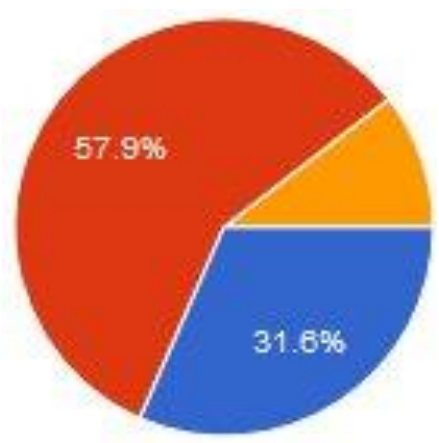

\section{Responda de maniera geral como avalia os colegas envolvidos no projeto}

(Optou-se pela publicação da soma das respostas para representar o grupo, e não as respostas individuais da participação de cada aluno)

\begin{tabular}{|l|r|}
\hline apresentou acentuada dificuldade em se relacionar com as pessoas & 1 \\
\hline apresentou facilidade em estabelecer contatos & 35 \\
\hline colaborou constantemente na resolução de problemas & 53 \\
\hline desenvolveu bem suas atividades & 38 \\
\hline necessitou orientação constante para melhorar seu relacionamento & 3 \\
\hline
\end{tabular}




\section{Anexo V: Questionário do perfil dos participantes da avaliação dos termos utilizados no ambiente desenvolvido}

Esse questionário foi elaborado com o objetivo de conhecer o perfil das pessoas que realizaram a validação dos termos usados no Tiê, aplicativo de comunicação e registro de projetos colaborativos que estamos desenvolvendo no Núcleo de Multimídia e Internet da Universidade de Brasília.

As perguntas a seguir buscam conhecer sua experiência em projetos em grupo e colaborativos, além da sua familiaridade com smartphones e aplicativos para auxiliar nesses tipos de projetos.

- Você usa smartphone Android? (sim/não)

- Você tem experiência com disciplinas que desenvolvem projetos? ( $\operatorname{sim} /$ não)

- Os projetos que você desenvolve são realizados em grupo? (sim/não)

- Nome

- Gênero

- Última formação concluída (Ensino médio/ Superior/ Outro)

- Área de formação/atuação (Design/Computação/Comunicação/Outro)

- Qual a marca do seu celular atual?

- Qual o modelo do seu celular atual?

- No total, qual o seu tempo de experiência usando smartphones? (até um ano/ de um a três anos / de três a cinco anos / mais de cinco anos)

- Você usa aplicativos para a comunicação e o gerenciamento de tarefas e/ou projetos no celular? Quais?

○ Whatsapp

○ Facebook Messenger

- SMS

○ Telegram

○ Slack

- Trello

○ Google Keep

○ Viber

○ Basecamp

○ Gmail 
○ Outlook

○ Outro

- Você já usou um dos aplicativos acima, mas não os usa mais? Se sim, por quê? (resposta aberta)

- Você tem experiência em trabalhar em projetos em grupo usando ferramentas colaborativas? Se sim, quais? (resposta aberta) 


\section{Anexo VI: Respostas ao questionário do perfil dos participantes da avaliação}

dos termos utilizados no ambiente desenvolvido

Todos os participantes da dinâmica de validação responderam ao questionário, resultando em um total de seis respostas.

- Você usa smartphone Android?

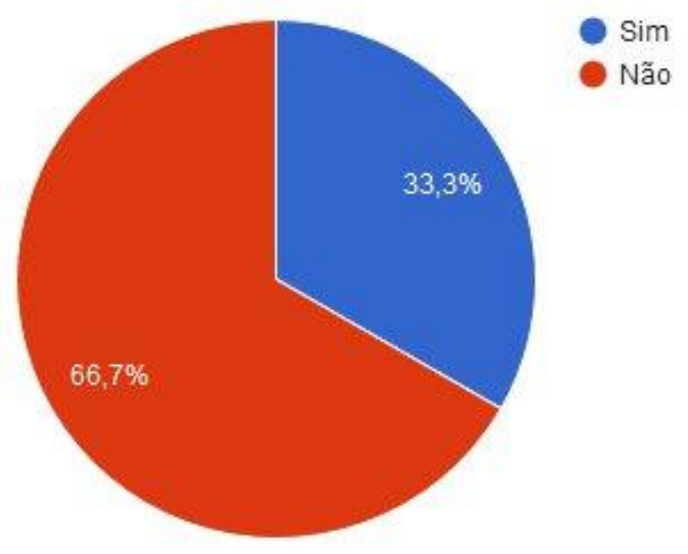

- Você tem experiência com disciplinas que desenvolvem projetos?

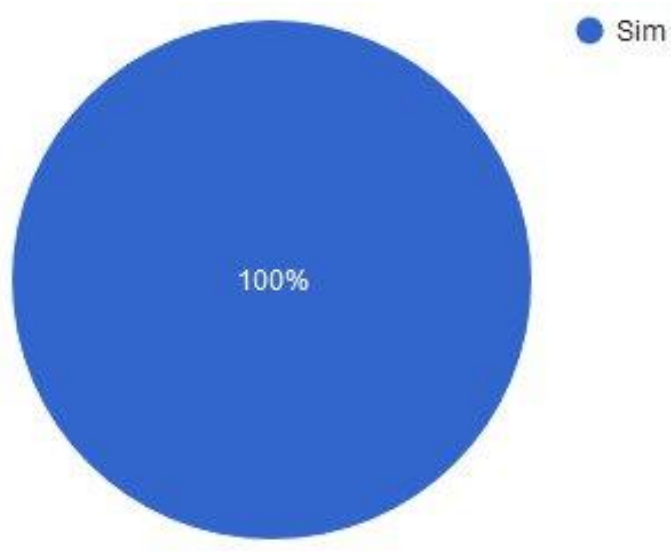

- Os projetos que você desenvolve são realizados em grupo?

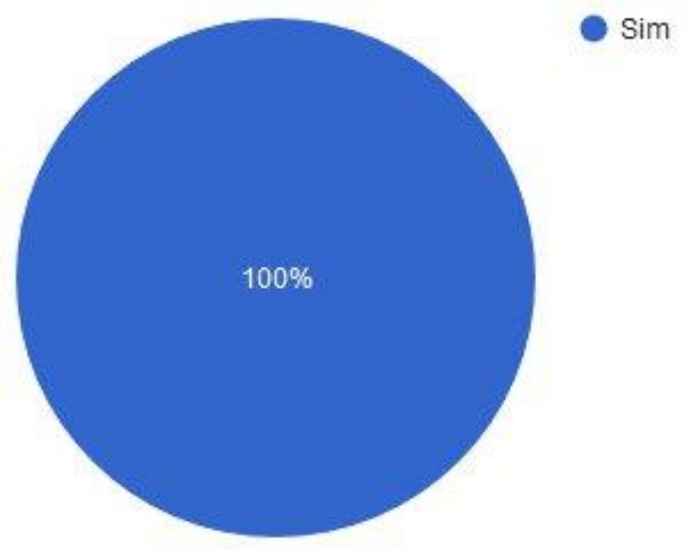


- Gênero

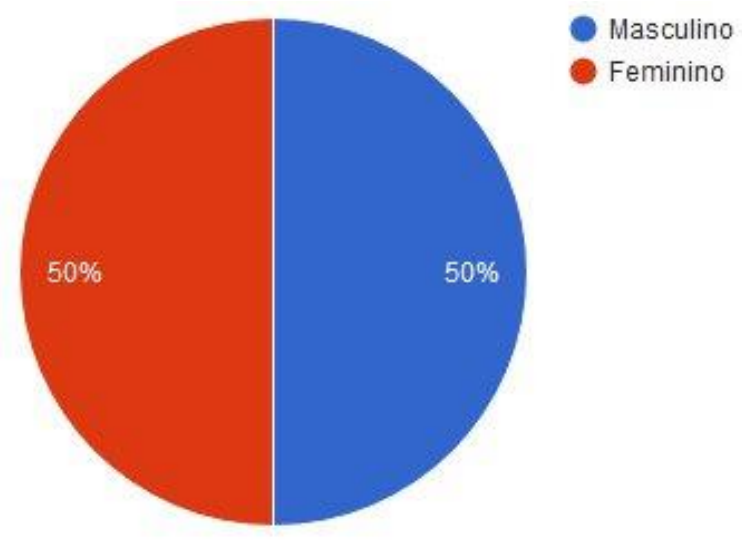

- Última formação concluída

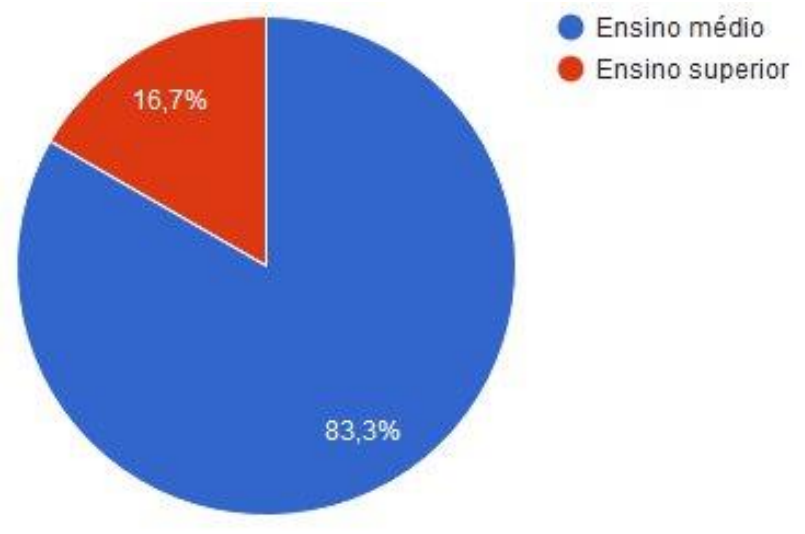

- Área de formação/atuação

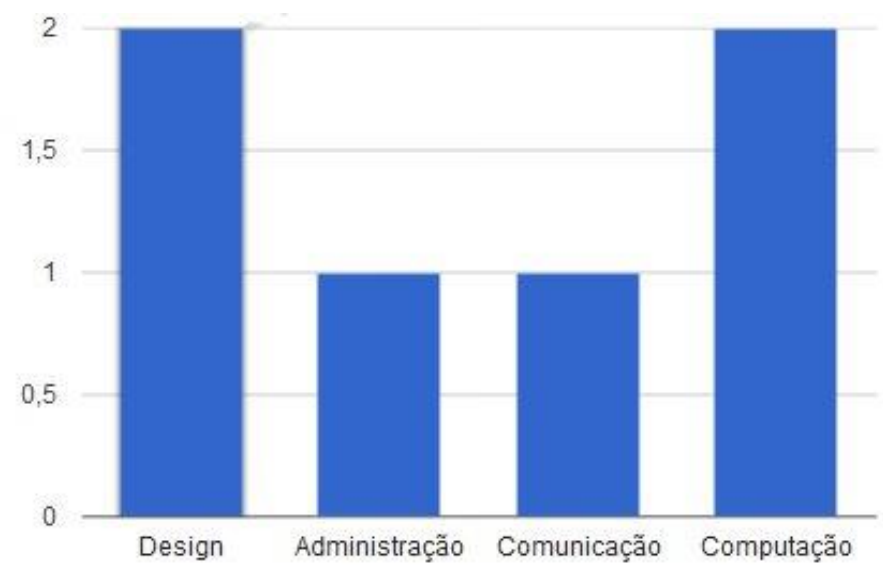


- Qual a marca do seu celular atual?

4

3

2

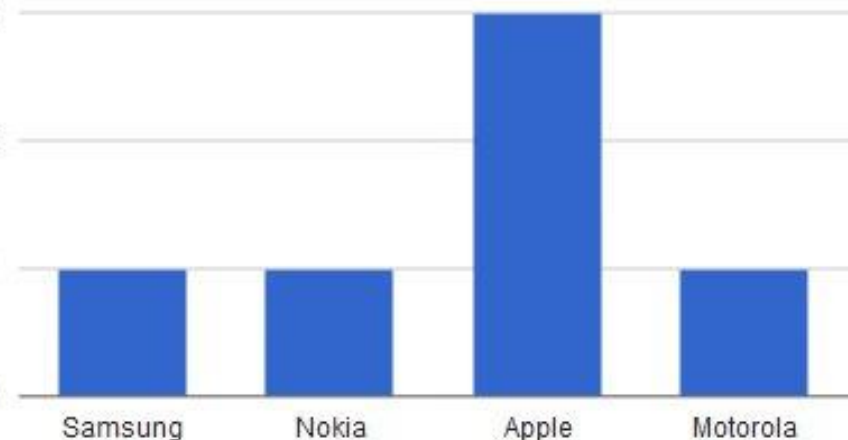

- Qual o modelo do seu celular atual?

Galaxy S2 TV

Nokia 630

iPhone 5s

iPhone 4s

iPhone 5

Rarz D3

- No total, qual o seu tempo de experiência usando smartphones?

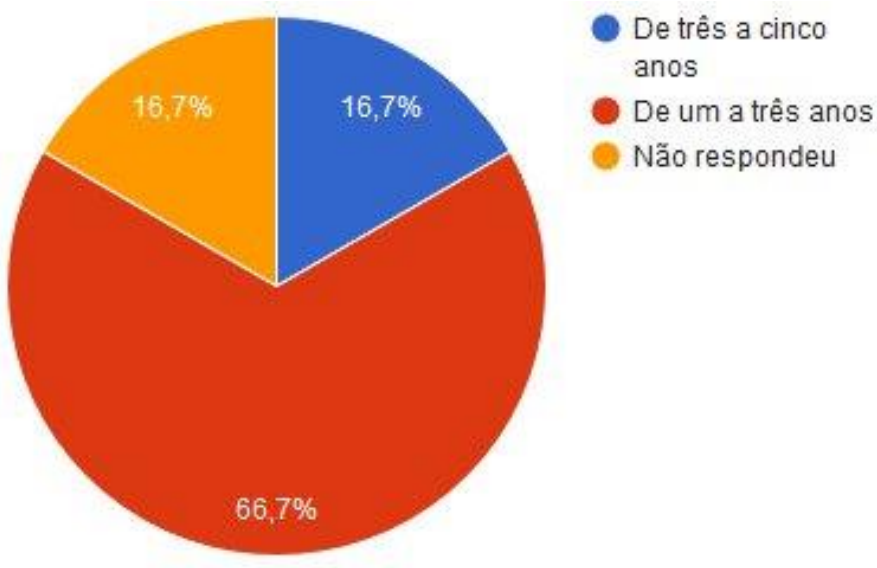


- Você usa aplicativos para a comunicação e o gerenciamento de tarefas e/ou projetos no celular? Quais?

\begin{tabular}{|l|r|r|}
\hline Whatsapp & 6 & $100,00 \%$ \\
\hline Gmail & 6 & $100,00 \%$ \\
\hline Facebook Messenger & 5 & $83,33 \%$ \\
\hline SMS & 2 & $33,33 \%$ \\
\hline Trello & 2 & $33,33 \%$ \\
\hline Viber & 1 & $16,67 \%$ \\
\hline Slack & 1 & $16,67 \%$ \\
\hline Outlook & 1 & $16,67 \%$ \\
\hline
\end{tabular}

- Você já usou um dos aplicativos acima, mas não os usa mais? Se sim, por quê? (Resposta aberta)

Meu telefone atual não tem muita memória. Mas quando tinha telefones com memórias maiores eu utilizava o Trello.

Não.

Trello - muito bagunçado e de difícil navegação

Sim, O Trello. Parei de usar por que não tinha o hábito de entrar com frequência.

- Você tem experiência em trabalhar em projetos em grupo usando ferramentas colaborativas? Se sim, quais? (Resposta aberta)

Apenas o google drive.

Não.

Sim. Principalmente o Trello e o Slack.

Google DOCs

Sim, Trello 


\section{Anexo VII: Roteiro da avaliação de usabilidade}

O roteiro foi elaborado de forma a estruturar uma atividade verossímil aos usuários, ou seja, uma sequência de tarefas fictícias, mas que se assemelham a projetos que ele desenvolva normalmente. Caso não conheça a rotina dos participantes, é interessante realizar uma observação anterior para projetar uma avaliação que seja mais próxima do contexto real de uso.

Esta sequência sugerida foi construída a partir da rotina de trabalho dos pesquisadores do Núcleo de Multimídia e Internet, que trabalham de forma colaborativa. Todavia, é um roteiro-base que pode ser adaptado para melhor se encaixar em outros contextos.

As tarefas destacadas ao longo do roteiro são as atividades que devem ser mantidas para avaliação. Elas foram baseadas no modelo CRUD (do inglês: Create, Read, Update and Delete), usado no desenvolvimento de sistemas para verificar se o sistema está funcional, testando as funções de criar, visualizar, editar, e deletar. Para o campo de usabilidade, deve ser realizada a análise da experiência do usuário para a realização destas tarefas.

Objetivo: Validar o ambiente e suas formas de uso para o usuário, compreendendo também estudos de interface

Amostra: 3 participantes, sendo que o estudo será feito com uma pessoa por vez

Equipe de aplicação: 3 pessoas

Pesquisador 1 (conduz a avaliação)

Pesquisador 2 (observador/ vídeo expressões e gestos)

Pesquisador 3 (observador/ vídeo tela)

Local: Sala que permita aplicação individual da avaliação

Material: 2 equipamentos de captura de áudio/vídeo, 1 roteiro de avaliação de usabilidade impresso, 2 Fichas do Projeto impressas, 4 cadeiras, 1 notebook (para preenchimento do questionário do perfil do usuário)

Procedimento: Solicitar ao participante que preencha o questionário do perfil do usuário online no notebook. Após o preenchimento, usar o roteiro de avaliação como 
guia para a apresentação da Ficha do Projeto para o usuário, guiando-o pela realização das tarefas e solicitando que ele fale em voz alta o que está pensando ao executar cada ação. Toda a avaliação será gravada em vídeo, capturando tanto as ações do usuário na tela do celular, quanto às expressões faciais e gestuais.

Resultados esperados: 10 vídeos de uso do aplicativo (2 de cada usuário) a serem analisados quanto às facilidades e dificuldades percebidas pelos usuários.

\section{Questionário do perfil do usuário}

Aplicar o questionário apresentado no anexo VI, selecionando apenas usuários que usem smartphones Android, pois a navegação difere entre sistemas operacionais

\section{Observações para condução da avaliação}

Apresentar-se ao participante e agradecer a disponibilidade dele. Avisar que a avaliação será gravada para análise posterior. Solicitá-lo que fale em voz alta quando estiver pensando sobre alguma dificuldade no desenvolvimento das tarefas.

\section{Roteiro de avaliação}

Imagine que você foi selecionado para liderar o projeto de organização do I Seminário Internacional de Economia Criativa, que deve acontecer na Semana Universitária, do dia 26 a 30/10 deste ano.

A professora Coordenadora é a coordenadora do projeto, e você irá trabalhar junto com outros dois bolsistas. Vocês estão usando o Tiê para organizar o projeto, mas vocês ainda não estão cadastrados. Você, como líder da equipe, precisa criá-lo!

[Entregar Ficha do Projeto]

\section{Ficha do Projeto}

1. Título: I Seminário Internacional de Economia Criativa

2. Descrição: Projeto de organização do I Seminário Internacional de Economia Criativa.

\section{Equipe:}




\begin{tabular}{|l|l|}
\hline Coordenadora & emaildocoordenador@email.com \\
\hline $\begin{array}{l}\text { Líder do projeto } \\
\text { (Você) }\end{array}$ & seu e-mail \\
\hline Bolsista 1 & emaildobolsista1@email.com \\
\hline Bolsista 2 & emaildobolsista2@email.com \\
\hline
\end{tabular}

\section{Informações a serem cadastradas:}

4.1 Evento: Abertura do Seminário (26/10 às 19h no Auditório da Faculdade de Tecnologia/UnB)

4.2 Tarefa: Criar cronograma do projeto. Você é o responsável pela tarefa.

\section{Informações a serem editadas:}

5.1 Nome do projeto: I Seminário Internacional de Economia Criativa da UnB

5.2 Descrição: Projeto de organização do I Seminário Internacional de Economia Criativa da Universidade de Brasília.

5.3 Evento: corrigir horário de abertura de $19 \mathrm{~h}$ para $18 \mathrm{~h}$

5.4 Tarefa: O cronograma já foi criado. Na verdade, você deve finalizá-lo.

Estou entregando a Ficha do Projeto, que tem as informações necessárias para criarmos o projeto no Tiê. Mas primeiro, você precisa se cadastrar no ambiente do Tiê para poder acessá-lo.

[Entregar celular ao usuário para que ele possa se cadastrar no ambiente]

Ok, feito o login, agora vamos cadastrar o projeto e convidar as outras pessoas da sua equipe, de acordo com os itens 1, 2 e 3 da Ficha do Projeto.

\section{[Acompanhar o cadastro do projeto e o convite de participantes]}

Bom, você cadastrou o projeto! Mas nos esquecemos de colocar na ficha que o nome completo do projeto é " I Seminário Internacional de Economia Criativa da UnB". 
Você pode, por favor, editar o nome do projeto e a descrição para arrumar essas informações de acordo com o que está escrito nos itens 5.1 e 5.2 da ficha?

\section{[Acompanhar a edição do nome e da descrição do projeto.]}

Certo, agora que arrumamos as informações do projeto, é hora de colocar um evento, ou seja, uma data importante para o projeto. No caso, o evento a ser cadastrado é a Abertura do Seminário, de acordo com o que está no item 4.1.

\section{[Acompanhar o cadastro do evento]}

Ok, o evento foi cadastrado... mas colocamos o horário errado na ficha! Você pode corrigir o horário da abertura para $18 \mathrm{~h}$ ?

\section{[Acompanhar a edição do evento]}

Obrigada! Agora vamos criar uma tarefa. Segundo a ficha, você é o responsável por criar o cronograma do projeto. Você pode cadastrar essa tarefa no Tiê, por favor?

\section{[Acompanhar o cadastro da tarefa]}

Ok, a tarefa foi cadastrada... mas para variar, temos que editá-la. Descobrimos que o cronograma já foi criado, mas ainda não está finalizado! Então, sua tarefa é, na verdade, finalizar o cronograma.

\section{[Acompanhar a edição da tarefa]}

Legal, você editou a tarefa! Agora, dentro desse ambiente você também pode procurar outros projetos para participar. Eu tenho um projeto que gostaria que você participasse dele. Pode pesquisá-lo? O nome dele é Alpha.

[Acompanhar a pesquisa do projeto e a solicitação de participação]

Agora que você está dentro do projeto, vamos ver apenas as tarefas dele para sabermos o que foi executado e o que está pendente.

\section{[Acompanhar a filtragem]}

Ok! Além de projetos, podemos pesquisar por usuários também para ver o perfil deles e saber em quais projetos estão trabalhando. Você pode pesquisar pela Cris para vermos os projetos nos quais ela está?

\section{[Acompanhar a pesquisa por outro usuário]}


Poxa, parece que ela não está em nenhum projeto aqui no Tiê... Depois perguntamos se ela tem interesse em participar do nosso. Agora, vamos compartilhar um arquivo dentro do projeto em que você acabou de criar. O Tiê se conecta ao Dropbox para compartilhar arquivos. Você tem uma conta lá?

[Acompanhar o possível cadastro no Dropbox para acessar arquivos. Compartilhar pasta no dropbox que contenha um arquivo cronograma.pdf]

Ok, como você tem cadastro no Dropbox, vou compartilhar uma pasta com você. Dentro dela tem o arquivo .pdf do cronograma para que você poste o link dele no dropbox na linha do tempo do aplicativo. Dessa forma ele fica registrado lá e as outras pessoas da sua equipe podem comentar sobre ele, ajudando você a finalizá-lo!

\section{[Acompanhar o upload do link do cronograma.pdf]}

Depois disso, agora peço que você edite seu próprio perfil, incluindo seu número de telefone para facilitar que os outros membros do projeto entrem em contato com você.

\section{[Acompanhar a edição do perfil]}

Ok, voltando ao projeto, a tarefa de editar o cronograma foi cancelada pela coordenação do projeto. Desta forma, você deve excluí-la :(

\section{[Acompanhar a exclusão da tarefa]}

Além da tarefa ter sido cancelada, a abertura do seminário também foi. Por favor, exclua o evento de abertura do seminário.

\section{[Acompanhar a exclusão do evento]}

Poxa, como se já não bastasse tudo isso, o Gabriel vai sair do projeto... Por favor, remova-o do projeto.

\section{[Acompanhar a exclusão do participante]}

Ah não, o projeto foi cancelado! Você deve excluí-lo.

[Acompanhar a exclusão do projeto]

Ok, muito obrigada pela sua participação na avaliação de uso do Tiê! 


\section{Anexo VIII: Roteiro das avaliações em contexto do ambiente desenvolvido}

\section{Avaliação em contexto}

Objetivo: Avaliar o uso do aplicativo em contexto, com equipes que estejam desenvolvendo projetos colaborativos.

Amostra: 6 participantes (quantidade de pessoas na equipe)

Procedimento: Disponibilização do aplicativo para que o grupo troque informações a respeito dos projetos em andamento. Estimular os usuários a enviarem por e-mail ou comentarem no Tiê as sugestões e dificuldades percebidas. Após sete dias de uso contínuo, aplicar Questionário de uso e percepção do ambiente com vistas a avaliar o uso e a percepção do ambiente.

Resultados esperados: 6 questionários de uso e percepção do ambiente preenchidos a serem analisados para a melhoria da solução desenvolvida.

\section{Questionário de uso e percepção do ambiente:}

$\underline{\text { Selecionar apenas usuários que usem smartphones Android, pois a navegação }}$ $\underline{\text { difere entre sistemas operacionais }}$

- Nome/Idade/Gênero

- Última formação concluída (ex: Médio, Superior, Especialização, Mestrado, Doutorado)

- Área (ex: Design, Ciência da Computação, Letras)

- Qual o modelo de celular atual?

- Tempo de experiência com uso de smartphones Android.

- Quais aplicativos costuma usar para comunicação e gerenciamento de tarefas/projetos no celular?

- Como o Tiê facilitou a comunicação e o registro dos seus projetos?

- Quais foram as dificuldades que surgiram com o uso do Tiê?

- Como o Tiê pode melhorar para melhor auxiliar a comunicação e o registro dos seus projetos? 